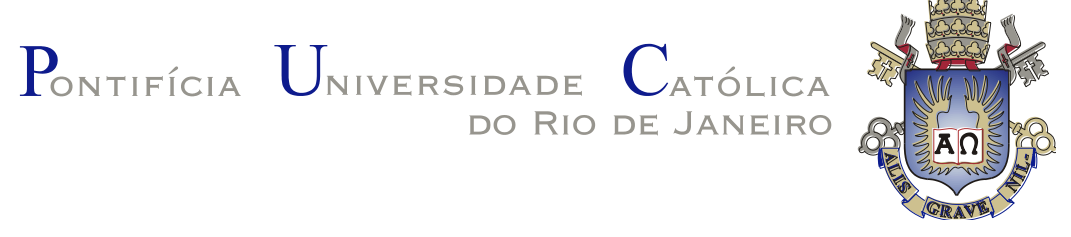

SANDRA ARAÚJO FERREIRA

\author{
Estudo do efeito da adsorção de metais alcalinos no \\ comportamento térmico da celulose em atmosfera inerte
}

Dissertação de Mestrado

Dissertação apresentada como requisito parcial para obtenção do grau de Mestre pelo Programa de PósGraduação em Engenharia de Materiais e de Processos Químicos e Metalúrgicos do Departamento de Engenharia Química e de Materiais da PUC-Rio.

Orientador: Prof. Rogério Navarro Correia de Siqueira Coorientador: Dr. Edelink Efrain Tinoco Falero

Rio de Janeiro

Dezembro de 2018 


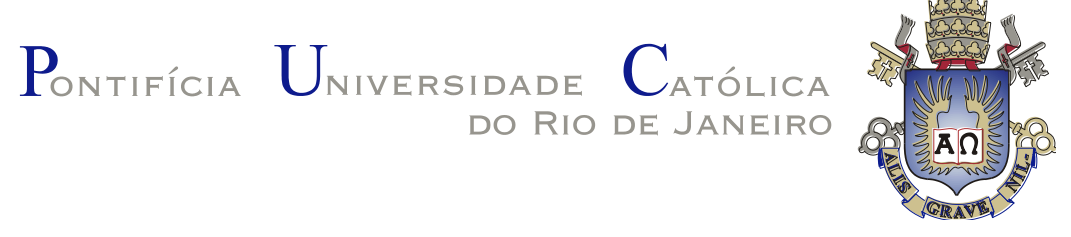

SANDRA ARAÚJO FERREIRA

\title{
Estudo do efeito da adsorção de metais alcalinos no comportamento térmico da celulose em atmosfera inerte
}

\begin{abstract}
Dissertação apresentada como requisito parcial para obtenção do grau de Mestre pelo Programa de Pós-Graduação em Engenharia de Materiais e de Processos Químicos e Metalúrgicos do Departamento de Engenharia Química e de Materiais da PUC-Rio. Aprovada pela Comissão Examinadora abaixo assinada.
\end{abstract}

Prof. Rogério Navarro Correia de Siqueira

Orientador

Departamento de Engenharia Química e de Materiais - PUC-Rio

Dr. Edelink Efrain Tinoco Falero

Coorientador

Departamento de Engenharia Química e de Materiais - PUC-Rio

Prof. Francisco José Moura

Departamento de Engenharia Química e de Materiais - PUC-Rio

Prof. José Brant de Campos

Departamento de Engenharia de Mecânica - UERJ

Prof. Rodrigo Fernandes Magalhães de Souza Departamento de Engenharia Química e de Materiais -

PUC-Rio

Rio de Janeiro, 20 de Dezembro de 2018 
Todos os direitos reservados. É proibida a reprodução total ou parcial do trabalho sem autorização da universidade, da autora e do orientador.

\section{Sandra Araújo Ferreira}

Cursou Ensino Profissional de nível técnico em Segurança do Trabalho no (INPA) Instituto Pedagógico Arcoense, 2010. Graduou-se em Engenharia Civil no UNIFOR-MG (Centro Universitário de Formiga) em 2015. Durante a graduação foi bolsista da FAPEMIG (Fundação de Amparo à Pesquisa do Estado de Minas Gerais) no Programa de Iniciação Cientifica. Cursou Especialização em Gestão Empresarial com Ênfase na Transformação Organizacional, na FGV (Fundação Getúlio Vargas).

Ficha Catalográfica

Ferreira, Sandra Araújo

Estudo do efeito da adsorção de metais alcalinos no comportamento térmico da celulose em atmosfera inerte / Sandra Araújo Ferreira; orientador: Rogério Navarro Correia de Siqueira; coorientador: Edelink Efrain Tinoco Falero. - 2018.

116 f.: il. color.; $30 \mathrm{~cm}$

Dissertação (mestrado)-Pontifícia Universidade Católica do Rio de Janeiro, Departamento de Engenharia Química e de Materiais, 2018.

Inclui bibliografia

1. Engenharia Química e de Materiais - Teses. 2. Celulose. 3. Hidróxido de magnésio. 4. Comportamento térmico. I. Siqueira, Rogério Navarro Correia de. II. Falero, Edelink Efrain Tinoco. III. Pontifícia Universidade Católica do Rio de Janeiro. Departamento de Engenharia 


\section{Agradecimentos}

Agradeço a Deus, aos amigos, aos professores, aos familiares envolvidos no desenvolvimento desta pesquisa e ao Conselho Nacional de Desenvolvimento Científico e Tecnológico (CNPq) pelo apoio financeiro. Dentre todas as pessoas envolvidas, houve algumas que foram de fundamental importância. São elas: Rogério Navarro Correia Siqueira, Edelink Efrain Tinoco Falero, Henrique Meira da Silva, Alan E. Ribeiro, Tamires Pimentel, Eliane C. Braga, Bruna Bronsato e Edna A. da Silva. 


\section{Resumo}

Ferreira, Sandra Araújo; Siqueira, Rogério Navarro Correia (orientador). Estudo do efeito da adsorção de metais alcalinos no comportamento térmico da celulose em atmosfera inerte. Rio de Janeiro, 2018, 116p. Dissertação de Mestrado Departamento de Engenharia Química e de Materiais, Pontifícia Universidade Católica do Rio de Janeiro.

Nos últimos anos, a crescente preocupação com meio ambiente e a empatia da sociedade com produtos sustentáveis têm fomentado o uso da celulose. A celulose é um biopolímero extensamente estudado pela humanidade em virtude de ser renovável, numerosa e em função de suas propriedades químico/físicas compatíveis com diversas finalidades. Neste trabalho, foi feito um estudo das fibras de celulose antes e após serem tratadas por diferentes concentrações de hidróxido de magnésio contidas em solução de PVA. O óxido de magnésio também se fez presente em sua forma calcinada. Métodos distintos foram realizados com a finalidade de aperfeiçoar o processo. Foi feita uma avaliação termodinâmica a fim de estudar os processos reacionais decorrentes da metodologia de síntese. Os materiais foram caracterizados por técnicas de MEV e DRX. Os resultados dos tratamentos e as propriedades das fibras foram avaliados por termogravimetria e análise cinética. $\mathrm{O}$ tipo de processo e a concentração do $\mathrm{MgO}$ e $\mathrm{Mg}(\mathrm{OH})_{2}$ usados no tratamento tiveram influência sobre o resultado no que tange ao comportamento térmico das amostras. Para a celulose pura o valor da energia de ativação foi de 53,702 kJ/mol e no caso da amostra VI o valor obtido foi de $43,64 \mathrm{~kJ} / \mathrm{mol}$. A amostra VI apresentou um valor inferior de Ea quando comparada à celulose pura, isso representa um menor consumo de energia para ocorrer a degradação térmica da fibra em atmosfera inerte, o que sugere um efeito catalítico dos íons de magnésio adsorvidos na celulose. Todas as amostras tratadas apresentaram características e propriedades diferentes da fibra inicial. Estudos mais detalhados se fazem necessários a fim de otimizar o processo e inferirem uma possível aplicação industrial das fibras tratadas.

\section{Palavras-chave}

Celulose; Hidróxido de magnésio; Comportamento térmico. 


\section{Abstract}

Ferreira, Sandra Araújo; Siqueira, Rogério Navarro Correia (advisor). Study of the effect of alkali metal adsorption on the thermal behavior of cellulose under inert atmosphere. Rio de Janeiro, 2018. 116p. Dissertação de Mestrado - Departamento de Engenharia Química e de Materiais, Pontifícia Universidade Católica do Rio de Janeiro.

Over the last few years, the growing concern about the environment and society's empathy towards sustainable products has instigated the use of cellulose. Cellulose is a biopolymer extensively studied by mankind given it's of renewable quality, it's numerous and because of its chemical and physical qualities that are compatible with a variety of means. For this project, a study of cellulose fibers was held before and after they were submitted to various concentrations of magnesium hydroxide, in its physical state and in solvents of PVA. Magnesium oxide was also present in its calcinated (powdered) form. Contrasting methodologies were applied in order to perfect the process. A thermodynamic evaluation was made to study the reaction processes resulting from the synthesis methodology. The materials were characterized by MEV and DRX. The results of the treatments and the properties of the fibers were evaluated by thermogravimetry and kinetic analysis. The type of process and the concentration of $\mathrm{MgO}$ and $\mathrm{Mg}(\mathrm{OH})_{2}$ used in the treatment were influential in the result when it comes to thermal behavior. For the pure cellulose the value of the activation energy was $53,70 \mathrm{~kJ} / \mathrm{mol}$ and in the case of sample $\mathrm{VI}$ the obtained value was $43.64 \mathrm{~kJ} / \mathrm{mol}$. The sample $\mathrm{VI}$ presented a lower value of Ea when compared to the pure cellulose, this represents a lower energy consumption to occur the thermal degradation of the fiber under inert atmosphere, which suggests a catalytic effect of the magnesium ions adsorbed on the cellulose. All of the samples showed substances and characteristics that differed from them original fiber. More detailed studies became necessary to optimize the process and interfere in a possible industrial application of the treated fibers.

\section{Keywords}

Cellulose; Magnezium hidroxide; Termal behavior. 


\section{Sumário}

1 Introdução 14

$\begin{array}{ll}\text { 1.1. Objetivos } & 17\end{array}$

$\begin{array}{ll}\text { 1.1.1. Objetivo geral } & 17\end{array}$

$\begin{array}{lr}\text { 1.1.2. Objetivos específicos } & 17\end{array}$

2 Revisão bibliográfica $\quad 18$

2.1. Materiais compósitos 18

2.1.1. Nanocompósitos 21

2.1.2. Fibras naturais lignocelulósicas 22

2.2. Celulose 24

2.2.1. Processos de obtenção da celulose 27

2.2.2. Aplicações das fibras de celulose 28

2.3. Óxido de magnésio $\quad 30$

2.3.1. Os compósitos com óxido de magnésio 33

2.4. Hidróxido de magnésio 36

2.4.1. Os compósitos com hidróxido de magnésio 39

2.5. Óxidos como catalisadores 41

3 Metodologia $\quad 45$

3.1. Materiais 45

3.2. Métodos 46

3.2.1. Síntese das matérias primas 46

3.2.2. Síntese das amostras de fibras de celulose tratada com hidróxido de magnésio e das amostras maceradas com óxido de magnésio: 49

3.2.3. Análises preliminares $\quad 55$

3.2.4. Avaliação termodinâmica das reações 56

3.2.5. Caracterização das amostras 56

3.2.6. Análise termogravimétrica 58

3.2.7. Cinética de decomposição usando análise termogravimétrica $\begin{array}{ll}\text { (TGA) } & 59\end{array}$

4 Resultados e discussões 63 
4.1.1. Variação de massa referente aos testes de solubilidade descritos no item 3.2.1.3 da metodologia.

4.2. Avaliação termodinâmica das reações

64

4.3. Caracterização dos materiais precursores pela difração de raios- $X 66$

4.3.1. Caracterizações da superfície dos materiais precursores $\quad 69$

4.4. Caracterização das amostras 72

4.4.1. Caracterização dos materiais posterior à análise termogravimétrica em atmosfera oxidante

4.4.2. Difratogramas obtido para: amostra I, amostra II, amostra III (sol.) e amostra IV (sol.).

74

4.4.3. Caracterizações da superfície das amostras tratadas 76

4.5. Avaliação das análises termogravimétricas $\quad 81$

4.6. Análise cinética de decomposição 92

4.6.1. Análise cinética de decomposição da fibra de celulose sem tratamento.

4.6.2. Análise cinética de decomposição da amostra VI

5 Conclusão

5.1. Sugestões para trabalhos futuros

6 Referências bibliográficas 


\section{Lista de figuras}

Figura 1: Tipos de distribuição de fibras em compósitos (adaptado de Callister \& Rethwisch, 2007). 20

Figura 2: Estrutura básica da celulose, destacando as ligações

glicosídicas. (Adaptado de Camargos, 2016) 25

Figura 3: Estrutura da celobiose (Ferreira et al., 2009). 26

Figura 4: Imagens de MEV do $\mathrm{Mg}(\mathrm{OH})_{2}$ (a) e (b); imagem de MEV do $\mathrm{MgO}$ auferido posterior a calcinação do $\mathrm{Mg}(\mathrm{OH})_{2}$ (c) (YU et al., 2004, p. 66 e 67)

Figura 5: Ensaio termogravimétrico da calcinação do $\mathrm{Mg}(\mathrm{OH})_{2} \mathrm{com}$

fluxo de $\mathrm{N}_{2}$, (Ding et al., 2001, p. 439)

Figura 6: Preparação da solução PVA 48

Figura 7: Aparato utilizado para filtragem a vácuo das amostras 50

Figura 8: Amostra I depois de ser filtrada (a), depois de sair do forno de mufla a $100^{\circ} \mathrm{C}$ por 45 minutos (b) e após ser extraída do papel filtro (c). 51 Figura 9: Representação do processo de síntese da amostra I. 51

Figura 10: Síntese da amostra macerada (mistura física) celulose + óxido de magnésio 54

Figura 11: Aparelho analisador termogravimétrico utilizado 59

Figura 12: Variáveis definidas na análise da cinética de decomposição do TGA. Speyer (1993). 61

Figura 13: Gráfico usado para determinar a energia de ativação e a ordem de reação da decomposição térmica. A inclinação indica uma reação de segunda ordem e o intercepto, sendo Ea $\emptyset / R\left(\emptyset=10^{\circ} \mathrm{C} / \mathrm{min}\right)$, indica que a energia de ativação é $111 \mathrm{kj} / \mathrm{mol}$ (Speyer, 1993). 
Figura 14: Diagrama de Pourbaix para o sistema $\mathrm{Mg}-\mathrm{O}-\mathrm{H}$ a $25^{\circ} \mathrm{C} \ldots \ldots \ldots . . .65$

Figura 15: Diagrama de decomposição do hidróxido de magnésio ...........66

Figura 16: Difratograma da fibra de celulose........................................67

Figura 17: Difratograma de raios-X do $\mathrm{Mg}(\mathrm{OH})_{2}$ em (a) e (b) e do $\mathrm{MgO}$

em (c) e (d) 68

Figura 18: Micrografias de MEV com gráfico de composição das fibras de celulose com magnificação de $250 \mathrm{X}$. 69

Figura 19: Imagens de MEV com mapas de EDS do $\mathrm{Mg}(\mathrm{OH})_{2}$ com magnificação de 340 vezes e do $\mathrm{MgO}$ com magnificação de 2000 X. ....71 Figura 20: Difratograma de raios-X das amostras I, II, III (solução) e IV (solução) em a), b), c), d) respectivamente. .74

Figura 21: Imagens de MEV da Amostra II, com magnificação de $500 x$ 77

Figura 22: Imagens de MEV da Amostra VI, magnificação de 12000 X...78 Figura 23: Imagens de MEV da amostra de celulose macerada com $10 \%$ de $\mathrm{MgO}$, magnificação de $500 \mathrm{X}$ 79

Figura 24: Imagem de MEV com mapas de EDS do resíduo proveniente do TGA feito da amostra VI em atmosfera oxidante, com magnificação de $1480 \mathrm{X}$. 80

Figura 25: Ensaio termogravimétrico da fibra de celulose sem

tratamento, da amostra I e da amostra II, em fluxo de $\mathrm{N}_{2}$. Na imagem a) Curvas de TGA b) a derivada respectiva (DTG) c) curvas de DTG ampliadas 82

Figura 26: Ensaio termogravimétrico da celulose sem tratamento, da amostra III e da amostra IV em fluxo de $\mathrm{N}_{2}$. Na imagem a) Curvas 
termogravimétricas, b) as derivadas das curvas termogravimétricas c) as curvas de DTG ampliadas.

Figura 27: Ensaio termogravimétrico da fibra de celulose, da amostra V e VI em fluxo de $\mathrm{N}_{2}$. Na imagem a) as curvas termogravimétricas, b) as derivadas das curvas termogravimétricas c) as curvas de DTG ampliadas

Figura 28: Ensaio termogravimétrico da celulose pura, da amostra com $5 \%$ de $\mathrm{MgO}$ e da amostra com 10\% de $\mathrm{MgO}$ macerados, em fluxo de N2. Na imagem a) Curvas termogravimétricas, b) as derivadas das curvas termogravimétricas e c) as DTG ampliadas. 89

Figura 29: Ajuste dos dados termogravimétricos da celulose pura; curva sem refinamento para determinar Ea da reação de degradação; dependência experimental da energia de ativação da celulose sem tratamento com o grau de conversão das reações de decomposição. ....93 Figura 30: Ajuste dos dados termogravimétricos da amostra VI; curva sem refinamento para determinar Ea da reação de degradação; dependência experimental da energia de ativação da amostra sem tratamento com o grau de conversão das reações de decomposição. ....95 


\section{Lista de tabelas}

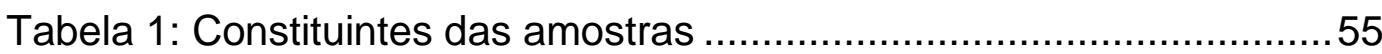

Tabela 2: Variação de massa para o teste de solubilidade......................64

Tabela 3: Resumo dos constituintes da amostra de celulose

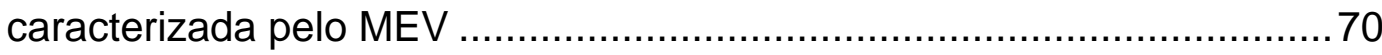

Tabela 4: Variação de massa das amostras estudadas, em atmosfera oxidante

Tabela 5: Parâmetros cristalográficos obtidos nas análises de DRX .......75

Tabela 6: Resumo dos resultados.......................................................

Tabela 7: Variação de massa em atmosfera inerte .................................91 


\section{Lista de siglas, abreviações e nomenclaturas}

ABNT - $\quad$ Associação Brasileira de Normas Técnicas

ALMACO- Associação Latino-Americana de Materiais Compósitos

EDS- $\quad$ Espectroscopia por dispersão de energia

Ea- $\quad$ Energia de ativação

DEQM - Departamento de Engenharia Química e de Materiais

DSC - $\quad$ Calorimetria Exploratória Diferencial

DTA - Differencial Thermal Analysis

DTG - Derivada da Termogravimetria

DRX- Difração de raios-x

FAO-ONU- Food and Agriculture Organization of the United Nations

IC- $\quad$ Índice de Cristalinidade (DRX)

MEV- Microscopia Eletrônica de Varredura

MET- Microscopia Eletrônica de Transmissão

PVA- Álcool Polivinílico

TG- Curva Termogravimétrica

TGA- Thermogravimetric Analysis

w/w- $\quad$ Peso por peso 


\section{Introdução}

Nos últimos anos tem surgido um crescente interesse mundial no desenvolvimento de tecnologias e materiais sustentáveis, os quais possibilitem menor impacto ambiental resultando em um ambiente mais limpo, saudável e sustentável (Jegatheesan et al., 2009). De acordo com Associação Latino-Americana de Materiais Compósitos, em 2017, o setor de compósitos, faturou $\mathrm{R} \$ 2,598$ bilhões, alta de 1,9\% comparando-se ao ano anterior (Almaco, 2017). Nesse sentido, diversos trabalhos e pesquisas na área de materiais compósitos vêm sendo realizados a fim de garantir a preservação ambiental e proporcionar um melhor padrão de vida à sociedade. (Packham, 2009).

Dentre as pesquisas que buscam a aplicação de recursos naturais na preparação dos materiais, destaca-se o uso de fibras naturais. As principais vantagens da utilização dessas fibras são: propriedades mecânicas específicas, baixa densidade, não-abrasividade, consumo de energia reduzido, propriedades mecânicas e termoacústicas adequadas (Bordes et al., 2009). Quando comparadas com as fibras sintéticas, incluem também aspectos ecológicos e sociais, em razão da melhor reciclabilidade, biodegrabilidade e do aumento da qualidade de vida dos habitantes de regiões onde é realizado o cultivo dessas fibras, oportunizando a oferta de empregos rurais (Bledzki; Gassan, 1999; Martins; Joekes, 2003).

A Organização das Nações Unidas para a Agricultura e a Alimentação (FAO-ONU - Food and Agriculture Organization of the United Nations) declarou o ano de 2009 como o ano internacional das fibras naturais. Essa iniciativa visou fomentar a utilização de fibras naturais, estimulando políticas governamentais de incentivo ao setor e às ações empresariais sustentáveis, para a exploração dessas matérias-primas. Conquanto haja diversas vantagens, existem também desvantagens, por exemplo, o fato de as fibras lignocelulósicas serem hidrofílicas e a 
variabilidade de propriedades pertinentes podem resultar em interface fibra-matriz mais fraca do que o esperado. Essas limitações podem ser superadas por meio de tratamentos superficiais, o que pode acarretar aumento de custo dos produtos reforçados com fibras lignocelulósicas.

Segundo Silva et al., (2009) os processos de fracionamento das fibras se fazem indispensáveis no intuito de possibilitar a utilização dos componentes estruturais isolados das fibras vegetais em aplicações específicas. A desagregação das fibras naturais em seus constituintes principais pode efetivar-se por vários mecanismos, os quais se baseiam nas diferenças químicas e estruturais que podem ser identificadas entre os componentes. Os principais constituintes das fibras vegetais são celulose, hemicelulose e lignina. A celulose se apresenta, a nível microscópico, em forma de fibrilas que são unidas pela matriz de lignina e hemicelulose, essas formam camadas que se diferenciam pela orientação fibrilar (loelovich et al., 2008). A celulose tem sido usada frequentemente nas mais diversas funcionalidades e aplicações, como na indústria têxtil (Mussato et al., 2007); na produção de fármacos (Cerqueira, 2009); nos itens light (Baruffaldi, 1998); biomateriais compósitos (Ekholm et al., 1999); cosméticos (Ishizu, 1991); em baterias de lítio (Hubbe; Rojas, 2008); nos compósitos (Gagnon et al., 2010; Wang et al., 2006; Yano; Nagayto, 2004); sendo pesquisada como fonte para geração de etanol (Olsson et al., 2006; ZHU et al., 2010) e na indústria papeleira (Mimms, 1993).

Outro setor que se encontra em plena ascensão é o nanotecnológico, o qual está focado em caracterização, fabricação, manipulação e aplicação de estruturas biológicas e não biológicas (Sahoo et al., 2007) em escala nanométrica. O prefixo "nano" está relacionado a uma escala de medida em que um nanômetro representa um bilionésimo do metro ou um milionésimo do milímetro. Estruturas nessa escala apresentam propriedades funcionais únicas não encontradas em escala macro (Chau et al., 2007).

$\mathrm{O}$ nanomateriais possuem singulares propriedades funcionais $\mathrm{e}$ estruturais, vantagens econômicas, disponibilidade, aprimoradas propriedades químicas e elevada área superficial (Barone \& Lattanzi, 
2015). A principal razão para as diferenças no comportamento entre materiais em escala nanométrica está relacionada com a elevada área superficial destes, resultando em intensa interação entre a matriz na qual estão inseridos e as nanopartículas. Diferentes nanomateriais vem sendo estudados e utilizados para diversas aplicações, dentre eles pode-se citar as nanopartículas de hidróxido de cálcio $\left(\mathrm{Ca}(\mathrm{OH})_{2}\right)$ e óxido de zinco $(\mathrm{ZnO})$ para a consolidação e proteção antifúngica de pedras calcárias de baixa porosidade (Gómez-Ortíz et al., 2013); atividades antibacterianas das nanopartículas de óxido de magnésio (MgO) (Makhluf et al., 2005; Nguyen et al., 2018); nanofibras de celulose (Mohanty et al., 2003) e nanoargilas (silicatos em camadas) (Bae et al., 2009) como aditivos para melhorar o desempenho e as propriedades de embalagens; têm sido utilizadas as nanopartículas de dióxido de titânio $\left(\mathrm{TiO}_{2}\right)$ dispersas em matrizes poliméricas para o revestimento hidrofóbico e consolidação de monumentos em mármore e calcário (La Russa et al., 2012); as nanopartículas de prata $(\mathrm{Ag})$ como desinfetante e antibactericídas, mais recente e pouco difundida, como anticorrosiva (Johnson et al., 2014); a utilização de nanopartículas de hidróxido de cálcio $\left(\mathrm{Ca}(\mathrm{OH})_{2}\right)$ e hidróxido de magnésio $\left(\mathrm{Mg}(\mathrm{OH})_{2}\right)$ para a desacidificação de madeira, papel e têxteis; aplicação de nanocristais de celulose e plastificantes para a consolidação de objetos arqueológicos em madeira (Christensen, Kutzke \& Hansen, 2012).

Em linhas gerais, as considerações acerca da decomposição desses materiais compósitos ainda se mostram reduzidas ao considerar o tamanho desse mercado em ascensão. Nesse sentido, pode ser uma alternativa com viés ambiental e econômico sugerir meios de inserir no processo de produção de tais materiais formas de acelerar a degradação térmica da celulose, quando esta se torna um rejeito e não tem outra aplicabilidade a não ser a destinação final. Uma possibilidade seria adicionar no processo de fabricação de materiais que contivessem a celulose tratamentos na própria fibra que acelerassem a degradação da mesma quando oportuno.

Sendo assim, tendo em vista a importância da celulose no atual contexto industrial e tecnológico, esta pesquisa se justifica, pois, visa 
sugerir formas de tratamentos na celulose que permitam acelerar sua degradação térmica. Desta forma, essa pesquisa tem por objetivo estudar o efeito da adsorção de metais alcalinos terrosos no comportamento térmico da celulose em atmosfera inerte.

\subsection{Objetivos}

\subsubsection{Objetivo geral}

Estudar o efeito da adsorção de metais alcalinos terrosos no comportamento térmico da celulose em atmosfera inerte;

\subsubsection{Objetivos específicos}

- Sintetizar os materiais precursores $\left(\mathrm{Mg}(\mathrm{OH})_{2}\right.$ e $\left.\mathrm{MgO}\right)$;

- Tratar as amostras de celulose com as soluções produzidas;

- Caracterizar os materiais por meio do DRX (quantificação das fases presentes e composição química), MEV com EDS (morfologia e composição química elementar), TGA em atmosfera oxidante (identificar $\mathrm{MgO}$ resídual);

- Realizar análise termogravimétrica em atmosfera inerte (estudo do comportamento térmico das amostras e posterior análise cinética). 


\section{Revisão bibliográfica}

Serão considerados nesta revisão bibliográfica os assuntos centrais, os quais serão pertinentes ao presente estudo e mostrar-se-ão correlacionados durante a execução do trabalho:

- compósitos e nanocompósitos, conceitos pertinentes, especificidades e aplicações;

- as fibras de celulose, sua estrutura, obtenção, propriedades, potencialidades;

- pesquisas, desenvolvimentos e aplicações de nanotecnologias;

- óxido de magnésio e hidróxido de magnésio, estrutura, obtenção, propriedades e funcionalidades;

- óxidos como catalisadores.

\subsection{Materiais compósitos}

Diante da necessidade do mercado, desenvolveu-se a metodologia de combinar diferentes materiais obtendo-se um compósito, esse capaz de satisfazer a demanda específica dos diferentes setores mercadológicos (Chawla, 1987). Produzir materiais compósitos não é uma concepção recente, de sorte que no início da década de 1960 surgiu um aumento da demanda por materiais com melhores propriedades mecânicas, porém mais leves, a fim de serem utilizados nos setores: naval, automobilístico, construção civil e aeronáutico.

De acordo com Callister \& Rethwisch (2007) em uma definição genérica, compósitos são materiais multifásicos que demonstram significativa proporção das melhores características de seus constituintes. Nesse sentido, o compósito segundo Smith (1998) é um material formado pela mistura ou combinação de dois ou mais constituintes, distinguíveis entre si, que se diferem na forma e na composição. Grande parte dos compósitos são formados por duas fases: a matriz (fase contínua) e a 
fase dispersa. A concentração, o tamanho, a distribuição e a organização das partículas ou fibras que compõem a fase dispersa são fundamentais para as propriedades mecânicas e térmicas dos compósitos (W. Callister \& Rethwisch, 2007). Um dos fatores que rege as propriedades dos compósitos é o modo de dispersão das fibras no mesmo. A mistura de fibra polar e higroscópica com uma matriz não polar e hidrofóbica pode resultar em dificuldade de dispersão da fibra na matriz. Agrupamentos e aglomerações são configurações das fibras que dificultam a produção de compósitos com boas propriedades. O uso de filamentos longos nos compósitos pode resultar em uma melhor distribuição, em contrapartida, fibras longas algumas vezes causam aumento na quantidade de agrupamentos, que acarreta áreas com elevada concentração de fibras e áreas com excesso de matriz, o que arrefece a eficiência e eficácia do compósito (Rowell, 1997); (Joseph, 2002); (Razera, 2004).

No meio ambiente, materiais compósitos existem há milhões de anos. Madeira, bambu e osso são exemplos da ocorrência natural destes materiais. O osso, por exemplo, consiste de uma mistura de fibras curtas e flexíveis de colágeno fixadas em uma matriz mineral de apatita, formando um compósito que suporta o peso dos vários membros do corpo (Chawla, 1987). O papel também é um material compósito, o qual é principalmente formado por fibras celulósicas atreladas entre si por interações intermoleculares (Schmied et al., 2013).

Segundo Leão (1997) o material de reforço pode ser fibra curta, longa, contínua, descontínua, pó, esfera, dentre outros e podem chegar a fornecer resistência como barras de ferro numa viga de concreto. A matriz envolve e segura o reforço, dando forma ao compósito. Abaixo do comprimento mínimo (critical length), as fibras deixam de atuar como reforço e fazem o papel de enchimento ou carga.

A escolha da matriz de um material compósito é de fundamental importância para a aplicabilidade do mesmo. O material utilizado como matriz confere estrutura ao compósito, cujas propriedades são função dos materiais constituintes, de suas quantidades relativas e da geometria do reforço. As matrizes poliméricas podem ser classificadas em termorrígidas, termoplásticas ou elastoméricas e podem apresentar 
características como hidrofilicidade ou hidrofobicidade, polaridade ou apolaridade e biodegradabilidade ou não biodegradabilidade (Faruk et al., 2012; Kabir et al., 2012; Satyanarayana; Arizaga; Wypych, 2009; Thakur; Karak, 2013).

Os compósitos podem classificar-se como reforçados com fibras descontínuas caso as suas propriedades sejam influenciadas pelo comprimento das fibras de reforço. Quando o comprimento das fibras de reforço é muito superior às dimensões da sua secção transversal, e o seu comprimento é tal que o aumento deste não provoca alterações nas propriedades do compósito, o material pode designar-se como compósito reforçado com fibras contínuas (Miracle \& Donaldson, 2001).

As orientações das fibras em compósitos e seus reforços podem ser: reforço contínuo e alinhado (a); reforço descontínuo e alinhado (b); reforço descontínuo e aleatoriamente orientado (c), conforme representação evidenciado na figura 1 (Callister \& Rethwisch, 2007). Baseado nessa classificação, utilizou-se nesse estudo reforço descontínuo e aleatoriamente orientado, haja vista que, compósitos com essas características valem-se de maior praticidade no preparo e equipamentos menos complexos para a síntese.

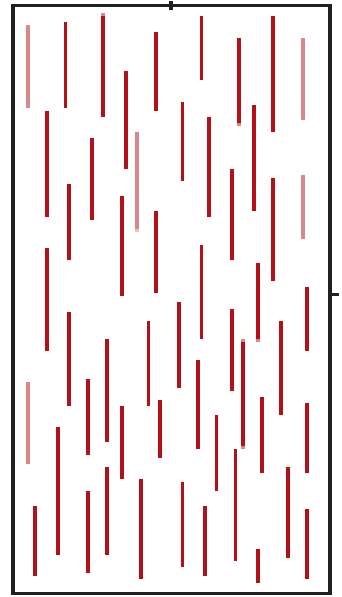

(a)

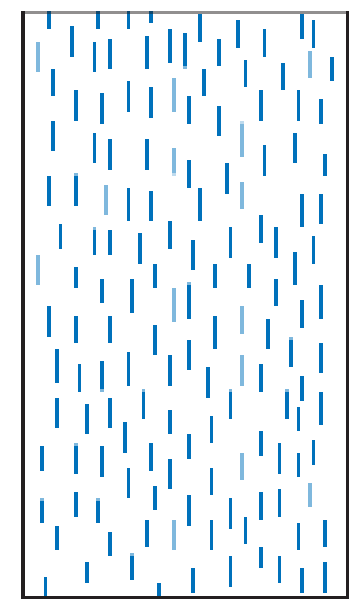

(b)

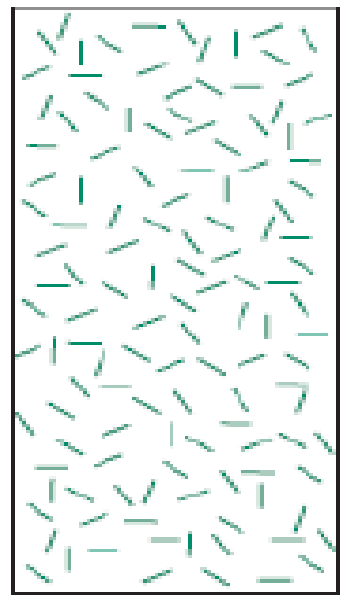

(c)

Figura 1: Tipos de distribuição de fibras em compósitos (adaptado de Callister \& Rethwisch, 2007).

No que tange às matrizes, essas podem ser de natureza polimérica, mineral ou metálica. No caso das matrizes poliméricas podem 
distinguir-se entre termoplásticas e termoendurecíveis (Gay \& Hoa, 2007). Os termoendurecíveis não fundem e tem como característica baixas viscosidades antes da polimerização, enquanto os termoplásticos podem ser fundidos, reprocessados e apresentam viscosidades mais elevadas que os termoendurecíveis, sendo fundamental perceber a influência que o tipo de matriz tem nas propriedades do compósito, na sua processabilidade e no custo (Miracle \& Donaldson, 2001).

Um fator importante do compósito é o efeito sinérgico que se espera poder observar na interação entre seus componentes (Joseph et al., 1999). Por exemplo, uma matriz reforçada com fibras beneficia-se mecanicamente quando a tensão a que é submetida é transferida para as fibras. Como as fibras naturais têm maiores módulos da proporção (resistência/peso), isso faz delas um componente óbvio para a aplicação em compósitos. A madeira é um exemplo natural de compósito, o qual compreende a celulose como reforço e a lignina como matriz (Leão, 1997).

\subsubsection{Nanocompósitos}

A característica marcante destes novos materiais, é a presença de cargas que possuem ao menos uma dimensão na escala nanométrica. No âmbito da dimensão nanométrica, as propriedades das nanopartículas apresentam, em geral, propriedades distintas daquelas relacionadas a partículas maiores dos materiais. Essa diferenciação se refere a importantes características como tamanho, distribuição e morfologia (Gurunathan et al., 2009).

Há uma gama de tópicos investigativos no que diz respeito aos nanocompósitos, principalmente incluindo aprimoramentos quanto às propriedades de nanopartículas utilizadas como reforço, às propriedades eletro-ópticas, às propriedades bactericidas, às propriedades de barreira, à flamabilidade dentre outras (Paul \& Robeson, 2008; Zheng et al., 2013). Dois processos fundamentais são usualmente aplicados para a obtenção das nanopartículas: a decomposição de estruturas sólidas em estruturas menores (processo top-down) e a síntese controlada das nanopartículas 
(processo bottom-up) ( Baglioni \& Giorgi, 2006). As nanopartículas já são usualmente aplicadas para a consolidação de pinturas murais, mármores e argamassas (Baglioni et al., 2013; Gómez-Villalba et al., 2010), e para a desacidificação de telas de pinturas, papel e objetos em madeira (Baglioni et al., 2013, 2012; Giorgi et al., 2002). Há o emprego de nanosistemas baseados em $\mathrm{Ca}(\mathrm{OH})_{2}$ e $\mathrm{ZnO}$ para a consolidação e proteção antifúngica de pedras calcárias de baixa porosidade (Gómez-Ortíz et al., 2013); o uso de nanopartículas de dióxido de titânio $\left(\mathrm{TiO}_{2}\right)$ dispersas em matrizes poliméricas para o revestimento hidrofóbico e consolidação de monumentos em mármore e calcário (La Russa et al., 2012); a utilização de nanopartículas de $\mathrm{Ca}(\mathrm{OH})_{2}$ e hidróxido de magnésio $\left(\mathrm{Mg}(\mathrm{OH})_{2}\right)$ para a desacidificação de madeira, papel e têxteis e pôr fim a aplicação de nanocristais de celulose e plastificantes para a consolidação de objetos arqueológicos em madeira (Christensen, Kutzke, \& Hansen, 2012).

Partículas em dimensão nanométrica são praticamente isentas de defeitos associados à estrutura hierárquica dos organismos ou compostos macro e micrométricos dos quais provém, haja vista, que sua aplicação no âmbito dos compósitos representa uma favorável oportunidade para arrefecer as falhas e limitações materiais peculiares aos compósitos tradicionais (Darder et al., 2007).

\subsubsection{Fibras naturais lignocelulósicas}

As fibras naturais são consideradas como materiais de origem animal, mineral ou vegetal (Scopel, 2012). Essas são constituídas de células alongadas e o entrelaçamento delas é, em parte, responsável por alguns atributos característicos como a densidade, a tensão, o módulo e o alongamento na ruptura. Conforme Silva et al., (2009), algumas fibras ocorrem espontaneamente na natureza, outras são cultivadas como atividade agrícola e ainda há aquelas que são resíduos gerados, principalmente, pela agroindústria.

No que diz respeito às fibras vegetais, cujo principal componente é a celulose, essas são também conhecidas como fibras lignocelulósicas ou biofibras. Elas são compostas essencialmente de celulose, hemicelulose e 
lignina. As fibras de coco, de bananeira, de palma, de curauá, de sisal, de juta, do bagaço da cana-de-açúcar, das palhas de arroz e de trigo, entre outras são exemplos de fibras vegetais tipicamente brasileiras (Kabir et al., 2012). O Brasil tem um grande potencial para produzir e comercializar diferentes fibras. Contudo, grande parte dessas fibras são descartadas, sem qualquer utilização se tornando resíduos agrícolas.

A utilização das fibras lignocelulósicas possibilitaria uma potencial fonte de recursos às populações (Goulart, 2010). Elas se mostram excelentes matérias-primas para a química de polímeros e compósitos, fato corroborado pelo eminente número de patentes nacionais e internacionais e o elevado número de produtos já comercializados (Silva et al., 2009). Existem algumas restrições associadas ao uso de fibras naturais como reforço em compósitos: as prováveis incompatibilidades entre fibras e matrizes poliméricas, a tendência a formar agregados durante o processamento, a baixa resistência à umidade, a inferior resistência ao fogo, as temperaturas de processamento limitadas, a menor durabilidade, a variação na qualidade e dificuldade em usar processos de fabricação uniformes (Dittenber et al., 2012).

Para Chen e seus colaboradores (2013) essas incompatibilidades entre os materiais das matrizes e as fibras acarretam desvantagens em comparação aos compósitos que usam fibra de vidro. A hidrofilia das fibras naturais indica a alta absorção de umidade das fibras, que é a principal razão da fraca adesão a matrizes hidrofóbicas e este faz com que os compósitos produzidos falhem em condições úmidas, ocasionando a rugosidade da superfície por inchamento das fibras (Dittenber et al., 2012). Nesse sentido, a umidade presente durante a fabricação de um compósito pode estimular uma baixa processabilidade e um baixo desempenho mecânico do compósito (Chen et al., 2013). Nos estudos de Araújo e colaboradores (2008), foi observado que a maioria das fibras naturais tem baixa temperatura de degradação (até $200^{\circ} \mathrm{C}$ ), a qual se mostra inadequada quando se trata de processamento com termoplásticos, haja vista que as temperaturas de processamento em geral são superiores a $200^{\circ} \mathrm{C}$. 
Em relação às vantagens e desvantagens das fibras naturais frente às sintéticas, Azwa e colaboradores (2013) ressaltaram que, apesar das fibras naturais, potencialmente, serem mais viáveis no que tange aos custos quando comparadas com as fibras sintéticas, cabe rememorar que a fim de superar seus inconvenientes podem incorrer custos adicionais às fibras naturais. Portanto, o processo precisa ser otimizado para competir com compósitos de fibras sintéticas, como as de vidro. Aspectos como variabilidade das culturas, dificuldades associadas ao armazenamento, transporte e processamento de fibras naturais corroboram para promover o aumento do preço.

Para Silva et al., (2009) o estudo dos processos de fracionamento das fibras possibilita a utilização dos componentes estruturais isolados das fibras vegetais em aplicações peculiares. A separação das fibras naturais em seus constituintes principais pode realizar-se por diferentes processos, baseados nas diferenças químicas e estruturais de cada componente. Esses processos, usualmente, têm como principal objetivo o isolamento das fibras de celulose.

\subsection{Celulose}

A celulose é um carboidrato do tipo polissacarídeo abundante nos vegetais. Ela consiste em até $50 \%$ da composição da madeira e é o principal componente da parede celular das células vegetais, conferindo rigidez para as plantas. Ela foi inicialmente identificada por Anselme Payen, em 1838, o qual a descreveu como um material sólido, resistente e fibroso, que permanecia mesmo depois da sujeição de tecidos vegetais a sucessivos tratamentos ácidos e básicos (Brown et al., 2007).

A estrutura básica da celulose (Figura 2) consiste de moléculas de cadeias longas, formadas por apenas três átomos - carbono, hidrogênio e oxigênio, apresentando as chamadas ligações glicosídicas $\beta$ (1->4) (Paist, 1958). Constituída por anéis $\beta$-1,4-anidro-D-glicopiranose (Lavoine, Desloges, Dufresne, \& Bras, 2012), a celulose possui estrutura polimérica característica. Cada monômero adota conformação em cadeira ${ }^{4} \mathrm{C} 1$, de menor energia livre, e apresenta três grupos hidroxila em posição 
equatorial, no plano dos quatro átomos de carbono centrais, enquanto os átomos de hidrogênio estão em posição axial (Habibi et al., 2010). Por meio de reações de polimerização por condensação, ligações glicosídicas são estabelecidas entre cada monômero. A ligação glicosídica $1 \rightarrow 4$ é formada por meio de um átomo de oxigênio covalentemente ligado, de maneira alternada, ao carbono 1 e ao carbono 4 de anéis consecutivos (Moon, Martini, Nairn, Simonsen \& Youngblood, 2011). A celulose se forma dentro das plantas, à medida que essas crescem, a partir da combinação dos três principais elementos que a compõe (Paist, 1958).

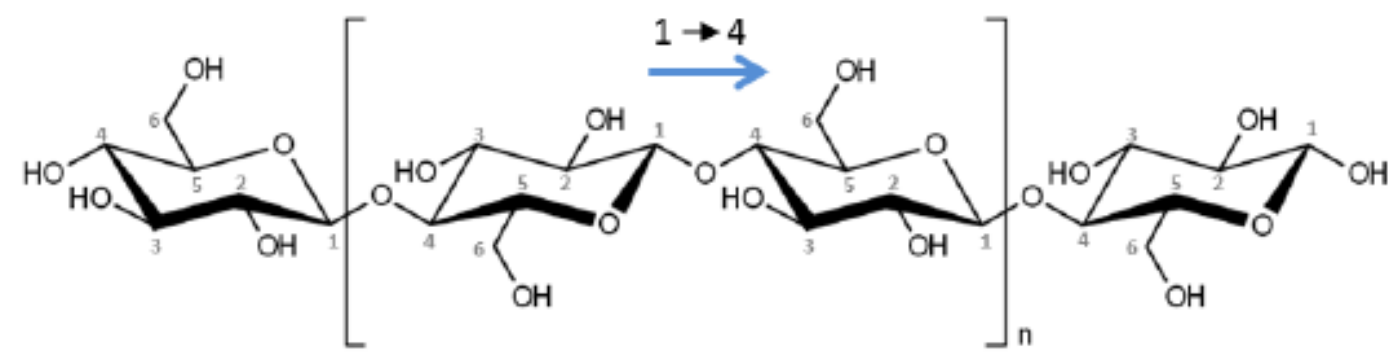

Figura 2: Estrutura básica da celulose, destacando as ligações glicosídicas. (Adaptado de Camargos, 2016).

Em relação à síntese dessa substância orgânica, Segundo Eichhorn et al., (2010) demonstraram que a celulose pode ser sintetizada por bactérias sob condições de cultura específicas, produzida por criaturas marinhas ou obtida através de plantas. A fórmula do polímero da celulose é $\left(\mathrm{C}_{6} \mathrm{H}_{10} \mathrm{O}_{5}\right) n$, onde $n$ é o grau de polimerização, sendo este um dos polímeros mais abundante da terra (Araújo et al., 2008). A cadeia da celulose é linear e de alto peso molecular, que tende a formar ligações de hidrogênio entre as moléculas (Mimms, 1993; Khalil et al., 2014). Os grupos hidroxilas das moléculas de celulose formam ligações de hidrogênio que podem ser intramoleculares ou intermoleculares, e são essas ligações que fazem com que a celulose seja um polímero estável (Moreira, 2009; Damásio, 2015).

A abundância de grupos hidroxilas, assim como o intenso sistema de ligações de hidrogênio (intra e intermoleculares), confirma as mais relevantes propriedades da celulose, tais como seu caráter hidrofílico, sua 
estrutura microfibrilar multi-escalar, sua grande natureza coesiva, que assegura a unicidade das fibras, a insolubilidade em água e a verificação de temperatura de transição vítrea superior à temperatura de degradação, e a organização hierárquica em regiões cristalinas e amorfas (Habibi et al., 2010; Lavoine et al., 2012; Moon et al., 2011). O grau de cristalinidade da celulose varia conforme sua proveniência e processamento. $\mathrm{Na}$ celulose originada do algodão observam-se cadeias mais ordenadas, e cristalinidade de aproximadamente $70 \%$, enquanto que a celulose de determinadas árvores apresenta índice de cristalinidade por volta de 40\% (Araújo et al., 2008).

A celulose é um polímero de cadeia longa e a sua unidade de repetição chama-se celobiose. Essa é constituída por dois anéis de anidroglucose unidos por uma ligação glicosídica $\beta-1,4$, conforme ilustra a Figura 3.

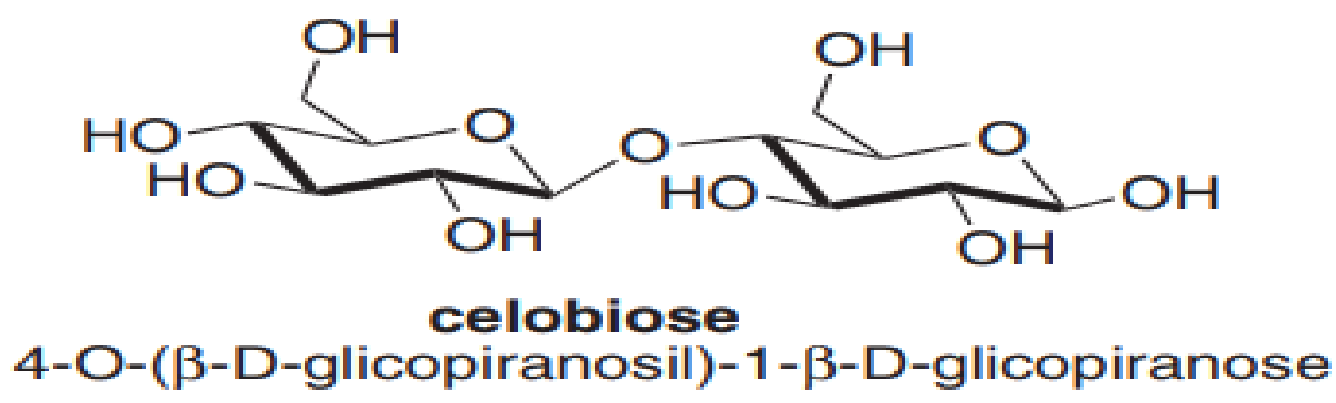

Figura 3: Estrutura da celobiose (Ferreira et al., 2009).

A celobiose é uma estrutura cristalina, porém, quando polimeriza para dar origem à celulose, forma também estruturas amorfas. A razão entre as estruturas amorfas e cristalinas na celulose tende a diferir de acordo com a sua fonte de obtenção na natureza (Eichhorn et. al., 2010; Chinga-Carraco, 2011).

Em relação às características conferidas pela celulose às fibras, os estudos de Azwa et al., (2013) relataram que na composição dessas, a celulose é responsável pela força, enquanto que as hemiceluloses pela resistência à degradação térmica, biológica e fatores relacionados à umidade, e a lignina pela resistência à degradação por radiação ultravioleta e formação. 


\subsubsection{Processos de obtenção da celulose}

Uma das formas de obtenção da celulose voltado para indústria de fabricação do papel, começa com o corte das árvores nas áreas de reflorestamento (Santos et al., 2001). Nesse processo, removem-se os galhos e as toras de madeira são cortadas em tamanhos apropriados e transportadas para a fábrica. Então, é comum em algumas indústrias que as cascas removidas sejam utilizadas para geração de energia, por meio de sua queima. As toras descascadas são lavadas e picadas em cavacos com dimensões apropriadas, para facilitar a difusão dos reagentes químicos que serão empregados. Quando estão na forma de cavacos, a madeira encontra-se pronta para a polpação (Correia, 2010). O processo de polpação objetiva a separação das fibras e melhorara suas propriedades para a fabricação do papel. Um dos métodos comuns para a polpação consiste num processo químico, no qual é retirado da madeira a maior parte da lignina, além de outros constituintes menos abundantes e desnecessários (D'Almeida, 1988).

Existem outros processos, nos quais a madeira é desfibrada mecanicamente com mínima remoção de seus constituintes, que também podem ser empregados. Esses processos levam a um aproveitamento quase total da madeira e, por isso, são chamados de polpações de alto rendimento. O processo Kraft, cujo processo é químico, também conhecido como de polpação, configura-se a principal rota para a obtenção de celulose (Maitam; Costa Jr. \& Souza, 2012). Na polpação kraft, os cavacos de madeira são submetidos à reação com uma solução contendo hidróxido de sódio $(\mathrm{NaOH})$ e sulfeto de sódio $\left(\mathrm{Na}_{2} \mathrm{~S}\right)$ conhecido como "licor branco" (D'Almeida, 1988). Isso ocorre dentro de um equipamento chamado de digestor, mantido a altas pressões e temperaturas. Os produtos químicos utilizados reagem com a lignina, fragmentando-a em substâncias de baixa massa molar que se solubilizam na solução alcalina e que podem ser removidas das fibras por inúmeras etapas de lavagem. A polpa ou pasta celulósica resultante da polpação (polpa marrom) ainda não é adequada para a produção de determinados tipos de papel, devido a sua coloração escura. Essa resultante de 
coloração escura é característica típica de pequenas quantidades de lignina que não foram removidas das fibras, denominadas nessa fase de lignina residual (Santos et al., 2001).

A fim de obter polpas totalmente brancas, é necessário remover essa lignina, por meio de um processo químico de branqueamento. Esse procedimento é complexo, visto que a lignina residual se encontra fortemente ligada às fibras. Nesse sentido, o branqueamento deve ser realizado em diversas etapas, assegurando a obtenção de polpas de alvuras elevadas, com mínima degradação da celulose. Nos vários estágios do processo de branqueamento da celulose, podem ser utilizados reagentes químicos como cloro $\left(\mathrm{Cl}_{2}\right)$, dióxido de cloro $\left(\mathrm{ClO}_{2}\right)$, hipoclorito de sódio $(\mathrm{NaClO})$, oxigênio $\left(\mathrm{O}_{2}\right)$ e ozônio $\left(\mathrm{O}_{3}\right)$, dentre outros (Assumpção et al., 1988). Entre uma fase de branqueamento e outra, a polpa é lavada com farta quantidade de água, para que as substâncias responsáveis pela coloração possam ser eliminadas (Santos et al., 2001).

\subsubsection{Aplicações das fibras de celulose}

Conforme Correia (2008) a celulose possui diversas propriedades úteis para aplicações na indústria, possuindo excelentes propriedades mecânicas, morfológicas, geométricas e superficiais, disponível em grande quantidade no meio ambiente, reciclável e com um baixo custo benefício de produção. A possibilidade de alterar a propriedades das fibras de celulose a partir da combinação e incorporação de outros materiais tornam essas fibras interessantes para estudo e aplicação como na indústria do papel (Mimms, 1993), em sua forma cristalina, como emulsificante em fármacos (Cerqueira et al., 2009), para conferir consistência em produtos lights (Baruffaldi, 1998), como base nos cosméticos (Ishizu, 1991), a fim de melhorar a resistência mecânica em filmes polieletrólitos de baixa espessura em baterias de lítio usados na medicina (Hubbe \& Rojas, 2008), no sentido de potencializar propriedades físico-mecânicas e até mesmo ópticas do papel (loelovich, 2010; Hassan et al., 2011), como matriz ou reforço de materiais compósitos, seja na forma cristalina ou amorfa (Gagnon et al., 2010; 
Wang et al., 2006; Yano; Nagayto, 2004). Além disso, ela tem sido pesquisada como fonte para geração de etanol (Olsson et al., 2006; Zhu et al., 2010) na qual os pré-tratamentos usados na madeira objetivam facilitar o ataque enzimático para fermentação dos açucares e é usada na indústria têxtil (Mussato et al., 2007) nesse caso, as celuloses são empregadas para retirada do excesso de corante no jeans, evitando danos às fibras do tecido.

A indústria automobilística vem demonstrando interesse na utilização de materiais reforçados com fibras naturais, para aplicação em componentes de revestimentos internos de veículos, como por exemplo, laterais, teto, painel, e também para elevar o conforto e atuar como elemento de acabamento (Mohanty et al., 2004; Kleba \& Zabold, 2004). A BMW tem investido no desenvolvimento de destes com estes materiais, visando entre outros aspectos, a preocupação com as questões ecológicas, o preço e a disponibilidade destes materiais na natureza (Mulinari, 2009). O BMW série 7, por exemplo, emprega $24 \mathrm{~kg}$ de materiais renováveis, dentre os quais mais de $13 \mathrm{~kg}$ são fibras naturais. Luz, Gonçalves e Del'Arco (2008) estudaram o processamento e a caracterização de compósitos de polipropileno reforçado com fibras de celulose e palha do bagaço de cana, direcionado para esse mercado automobilístico.

Em relação a degradação das fibras Azwa et al., (2013) fizeram uma revisão abrangente acerca desse assunto em compósitos poliméricos baseados em fibras naturais. Eles avaliaram as características de vários compósitos de fibra natural expostos às intempéries de umidade, às degradações térmica e de radiação ultravioleta. Os efeitos de aditivos químicos, como tratamentos das fibras, retardadores de fogo e estabilizadores ultravioleta (UV) também foram abordados. Baseados nas avaliações, concluíram que embora conteúdo de fibra ideal forneça força para um compósito polimérico, ele também se torna um ponto de entrada para ataques de umidade. Alguns tratamentos das fibras estão sendo usados para melhorar a interface fibra/matriz, e conseguem aumentar a durabilidade da resistência à umidade. No entanto, eles verificaram que as fibras tratadas se comportam mal quando expostas ao tempo. A adição 
de estabilizadores de radiação ultravioleta e retardadores de fogo foi sugerida a fim melhorar o desempenho frente ao fogo na fibra natural/composto de polímero, mas a sua força ficou comprometida. Diante dos dados coletados e resultados experimentais, o desfecho apontou para o emprego de aditivos para se alcançar um equilíbrio entre os requisitos de resistência e durabilidade para compósitos de fibras naturais.

Em outro estudo acerca das fibras de celulose, Zhang et al., (2016) considerou-se que as fibras de celulose, apesar de suscetíveis à degradação, podem ter o seu comportamento de degradação melhorado pela incorporação de íons metálicos, levando a um retardamento da chama nessas fibras. $\mathrm{O}$ íon de zinco foi enxertado nas fibras de celulose. Primeiramente, enxerto de anidrido maleico nas fibras de celulose por meio da reação de acilação homogênea entre $\mathrm{N}, \mathrm{N}$-dimetilformamida (DMF). Em seguida, o enxerto de zinco sobre as fibras de celulose formadas foi conduzido com carbonato de zinco. O retardamento à chama e a degradação térmica de fibras de celulose modificadas com íons zinco (fibras celulósicas-Zn) foram investigados. Seus resultados mostraram que esse íon pode efetivamente melhorar o retardamento de chama e a degradação térmica quando seu conteúdo aumenta para até 4,96\% em peso. Estudos como este revelam e sugerem a possibilidade de modificar algumas propriedades dessas fibras mediante a incorporação de materiais iônicos.

\section{3. Óxido de magnésio}

O óxido de magnésio ( $\mathrm{MgO}$ ) é um composto químico formado a partir de uma ligação iônica entre um átomo de magnésio e oxigênio, cuja massa molecular é de 40,30 u.m e com densidade de $3,5 \mathrm{~g} / \mathrm{cm}^{3}$ (Amaral et al., 2007). Segundo as informações contidas na sua ficha de informações de segurança de produtos químicos (FISPQ), é um sólido branco, não perigoso, inodoro, pouco solúvel em água, com ponto de fusão à $2800^{\circ} \mathrm{C}$ e temperatura de ebulição $3600^{\circ} \mathrm{C}$. 

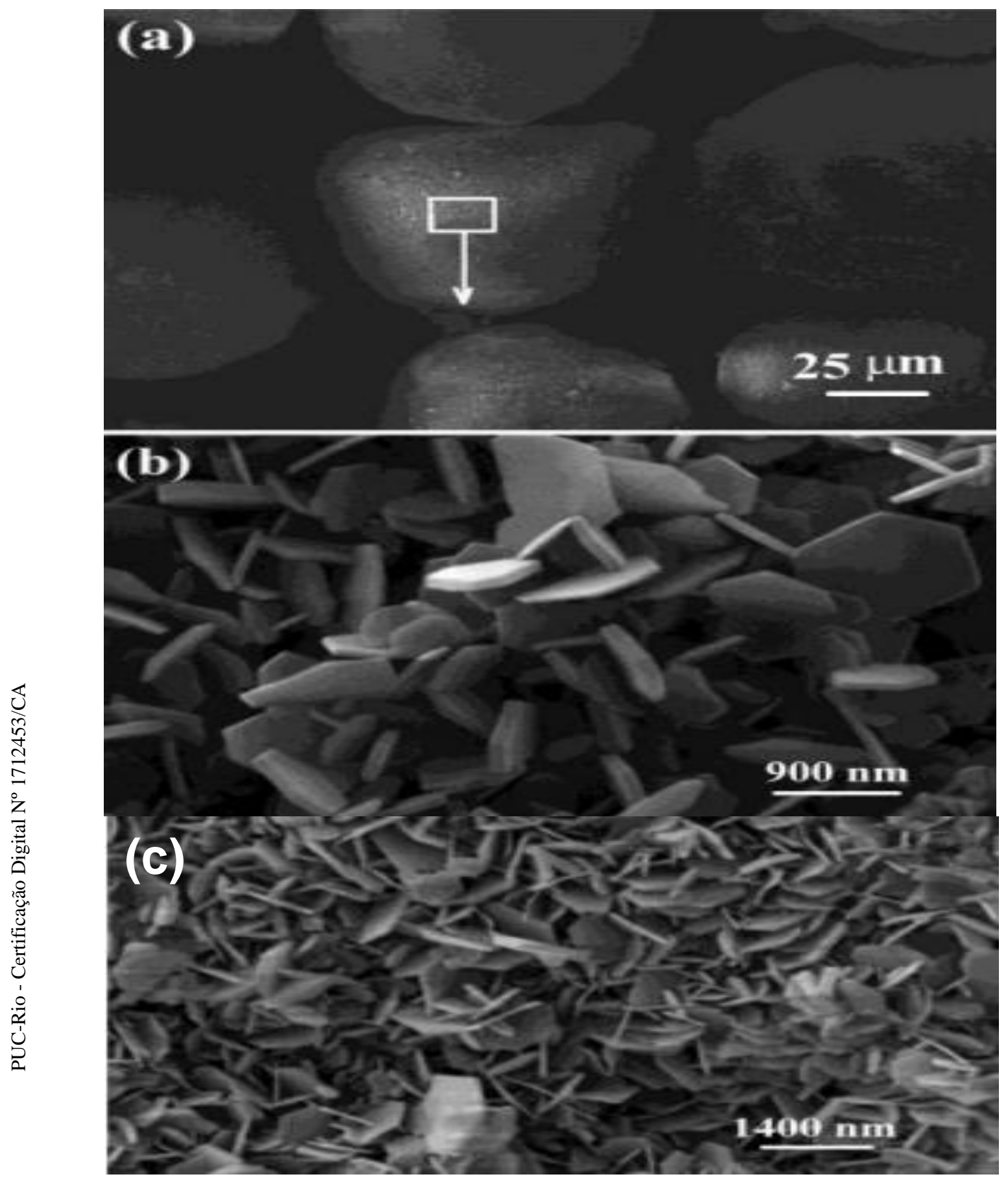

Figura 4: Imagens de MEV do $\mathrm{Mg}(\mathrm{OH})_{2}$ (a) e (b); imagem de MEV do $\mathrm{MgO}$ auferido posterior a calcinação do $\mathrm{Mg}(\mathrm{OH})_{2}$ (c) (YU et al., 2004, p. 66 e 67).

Na figura 4 (a) obtida com baixa magnificação, percebe-se uma morfologia em formato de esferas, com dimensões de aproximadamente $25 \mu \mathrm{m}$. Na parte (b) da figura, com alta magnificação visualiza-se placas hexagonais bem definidas, com dimensões de aproximadamente de 900 $\mathrm{nm}$. Os autores relatam que as placas têm espessura dentre 50 a $110 \mathrm{~nm}$, 
e podem ser confrontadas com as imagens obtidas pela literatura no que diz respeito ao $\mathrm{Mg}(\mathrm{OH})_{2}$ (brucita). Esse nível de detalhamento se faz importante a fim de se mapear as o comportamento do material em um processo de adsorção. Na figura 4 (c), detalhes acerca do MgO obtido depois da calcinação do $\mathrm{Mg}(\mathrm{OH})_{2}$ são demonstrados. Na escala de 1400 $\mathrm{nm}$, a morfologia das placas hexagonais é conservada e bem definida.

Segundo Araújo et al., (2011), o magnésio é o sexto elemento mais abundante dentre os que formam a crosta terrestre. Embora seja encontrado em mais de 60 minerais, somente dolomita, magnesita, brucita, periclásio ( $\mathrm{MgO}$ ), carnalita e olivina (forsterita) são de importância comercial. Magnésio e seus compostos são também extraídos a partir de água do mar e salmouras de poços e lagos.

A principal utilização do magnésio, normalmente sob a forma de óxido, é como material refratário em revestimento de fornos para a produção de ferro e aço, metais não-ferrosos, vidro e cimento (Amaral et al., 2007). O Óxido de magnésio e outros compostos são ainda usados em agricultura, indústria química e na construção. Segundo Salomão et al., (2007), nessa classe de materiais, os concretos refratários contendo óxido de magnésio ou magnésia $(\mathrm{MgO})$ destacam-se devido a uma série de vantagens como sua elevada refratariedade e boa resistência ao ataque por escórias básicas. Em combinação com óxido de alumínio $\left(\mathrm{Al}_{2} \mathrm{O}_{3}\right)$, pode levar à formação de espinélio $\left(\mathrm{MgAl}_{2} \mathrm{O}_{4}\right)$, que possui boa resistência ao choque térmico, além de custo competitivo (Amaral et al., 2007). As vantagens técnicas aliadas aos aspectos econômicos tornaram-se a motivação de muitos estudos na área de refratários. Yu e colaboradores (2004), relataram que nos últimos anos o $\mathrm{MgO}$ tornou-se um dos materiais mais pesquisados no âmbito de análise estrutural de superfícies e catálise.

Em ligas com o alumínio, o magnésio é usado em componentes estruturais de automóveis, máquinas e latas para bebidas. (Garcia et al., 2013). Além de todas essas possibilidades de aplicações, a presença de sítios básicos na superfície do óxido, combinado com áreas específicas elevadas, possibilita seu uso como catalisador de muitos processos orgânicos (Meshkani, 2009). 
Segundo Fernández-García et al., (2004) as nanopartículas do óxido de magnésio apresentam cátions penta coordenados na face (100) que têm carga próxima daqueles presentes na estrutura do tipo bulk. A questão é que esses átomos têm baixa atividade e podem não ser úteis para determinadas aplicações nas quais há a inserção das nanopartículas. Por outro lado, as espécies localizadas no canto ou nas bordas desses materiais apresentam baixo número de coordenação e uma carga positiva menor do que no bulk. Esses cátions podem ser os sítios ativos na estrutura do óxido. Além disso, há de se considerar a presença de vacâncias de oxigênio na estrutura do óxido nanoestruturado, o que influencia suas propriedades químicas e eletrônicas. As vacâncias aniônicas para o óxido tratado são denominadas "centro $\mathrm{F}$ " e podem ser do tipo $\mathrm{F} \mathrm{F}^{+}$e $\mathrm{F}^{2+} \mathrm{o}$ que se refere respectivamente à remoção de um átomo de oxigênio, de uma espécie $\mathrm{O}$ ou de um ânion $\mathrm{O}^{2-}$. Os centros $\mathrm{F}$ indicam um par de elétrons "aprisionados" na cavidade deixada pelo oxigênio que está em falta. Os centros $\mathrm{F}^{+}$estão relacionados a um único elétron associado com a vacância. Já os centros $\mathrm{F}^{2+}$ são fortemente deficientes de elétrons e têm uma tendência de ionizar moléculas ligadas (Fernandes-Gárcia et al., 2004 \& Zhao et al., 2011).

\subsubsection{Os compósitos com óxido de magnésio}

$\mathrm{Na}$ literatura alguns estudos têm explorado a síntese de compósitos com diferentes aplicações, empregando o óxido de magnésio. Recentemente, Li e colaboradores (2017), a partir da via de polimerização em emulsão in-situ sintetizaram microcápsulas de $\mathrm{MgO}$ e $\mathrm{MgO}$ (sem encapsulamento) e foram incorporados separadamente em fibras de celulose por mistura de fiação úmida, com emissão de plasma acoplado indutivamente. Os resultados revelaram que as fibras de celulose modificadas com as microcápsulas de $\mathrm{MgO}$ continham mais $\mathrm{Mg}^{2+}$ que os modificados por $\mathrm{MgO}$ puro, indicando maior resistência ácida. A degradação de fibras de celulose modificadas (fibras de celulose-Mg) foi estudada por calorímetro (CONE), termogravimetria (TGA), e a 
determinação do índice de oxigênio limitante (LOI). O valor mínimo da LOI obtido para as fibras de celulose-Mg foram de 35 , sendo muito superiores às da fibra de celulose não modificada.

Contudo, o foco principal do trabalho foi a investigar meios de melhorar as propriedades retardadoras de chamas das fibras de celulose por incorporação de microcápsulas de $\mathrm{MgO}$. Eles encontraram resultados que indicam a taxa de liberação das fibras de celulose-Mg significativamente menor que a das não-dopadas. As curvas TGA mostraram que os resíduos gerados aumentaram de 13,79\% (fibra de celulose) para 30,26\% (fibra de celulose-Mg).

Entres as pesquisas que envolvem o uso de nanopartículas de óxido de magnésio um tema se mostra recorrente e promissor, (Makhluf et al., 2005); (Nguyen et al., 2018), atividades antibacterianas das nanopartículas de $\mathrm{MgO}$, a rota de síntese sugerida por eles indica que partículas nanocristalinas de $\mathrm{MgO}$ foram sintetizadas usando radiação de micro-ondas em uma solução de etilenoglicol. Os estudos examinaram a importância do efeito das dimensões, do $\mathrm{pH}$ e da forma das espécies ativas de $\mathrm{MgO}$ como agente bactericida. Os resultados apontaram uma clara dependência de tamanho das nanopartículas, evidenciadas quando se concluiu que quantidade de bactérias erradicadas era fortemente dependente do tamanho das partículas. Nesse sentido, o estudo agrega informações sobre o $\mathrm{nMgO}$ aplicado como um biomaterial antimicrobiano para engenharia de dispositivos médicos livres de infecção e implantes no futuro.

No que diz respeito às pesquisas que envolvem a síntese de compósitos a partir de celulose e diferentes óxidos, podem-se destacar os estudos com diversas finalidades como a de Wang et al., (2012), que produziram filmes a partir de micro celuloses e óxidos de grafeno (OG). $O$ objetivo, nesse caso, era avaliar o impacto da dispersão do reforço na matriz. $O$ estado de distribuição do $O G$ foi investigado por medidas reológicas e mostraram que este começou a formar uma estrutura de rede quando o seu conteúdo superou a $0,155 \%$ em peso. Os resultados demonstraram uma dispersão homogênea do óxido em uma matriz de micro celulose. Imagens micrografias dos filmes revelaram a agregação 
do óxido quando o conteúdo deste foi superior a $3 \%$ em peso. Análises TGA das propriedades térmicas mostrou um efeito combinado do óxido de grafeno e a micro celulose. O compósito ganhou melhores propriedades mecânicas, ou seja, sua resistência à tração e à tensão para fratura foram notavelmente aumentadas em 64,7 e 85,1\%, respectivamente, em comparação com o filme de micro celulose puro. Estes concluíram que a dispersão uniforme do óxido de grafeno na microcelulose poderia melhorar significativamente as propriedades dos filmes, devido à forte adesão entre cadeias dos materiais. Enquanto o aumento da porcentagem do óxido no compósito reduziria as propriedades mecânicas do filme devido à agregação e ruptura da homogeneidade do filme.

Algum tempo depois, Anirudhan e colaboradores (2017) estudaram a adsorção e a degradação de um antibiótico, o ciprofloxacin (CF) amplamente utilizado em as aves de capoeira, por meio de um novo catalisador fotográfico composto de nano óxido de zinco incorporado com óxido de grafeno e nanocelulose (ZnO-GO/NC). Esse nanocompósito obteve melhor desempenho catalítico fotográfico mediante à injeção de elétrons fotossensibilizada. Esses recursos tornaram o composto $\mathrm{ZnO}$ GO/NC um candidato recomendável para aplicações relacionadas com a poluição aquosa do meio ambiente. O Catalisador foi caracterizado por diversas técnicas, como MEV, DRX e técnicas potenciométricas. $\mathrm{O} \mathrm{pH}$ ótimo foi de 5,5 e a dose de adsorvente foi de 2,0 g/L. Os dados cinéticos de adsorção foram melhor equipados com modelo cinético de pseudosegunda ordem sugerindo interação de $\mathrm{CF}$ em ZnOGO/NC como ligação de hidrogénio, bem como iónica. $A$ regeneração e a reciclabilidade do adsorvente foram testadas durante cinco ciclos. A viabilidade do catalisador na situação da vida real foi realizada utilizando amostras de água coletadas de fonte de água perto de explorações avícolas, para se aproximar o máximo possível da realidade. Eles concluíram que o método de síntese pode ser estendido para adicionar mais grafeno aos compósitos a fim de aplicá-lo no campo das biomoléculas e dispositivos nanoeletrônicos. Diante do exposto, eles entenderam que estas características tornam o compósito $\mathrm{ZnO}-\mathrm{GO} / \mathrm{NC}$ como postulante a 
aplicações relacionadas à poluição aquosa ambiental. Os resultados revelaram que a degradação alcançou eficiência máxima de 98,0\%.

Seguidamente, Kong et al., (2018) publicaram um estudo que relata as propriedades e caracterização estrutural do óxido de celulose-ferro, compostos com teor variável de óxido de ferro. Segundo eles, embora haja estudos sobre a celulose revestida com óxido de ferro, é necessária uma compreensão mais detalhada da estrutura e das propriedades de adsorção desses materiais. Para isso, usaram de vários métodos de caracterização, tais como TGA, DRX, microscopia eletrônica de transmissão (MET) dentre outros. Os resultados experimentais da síntese da formação do compósito de óxido de ferro e das experiências de lixiviação de $\mathrm{Fe}$ indicaram que os materiais compósitos apresentaram um nível ótimo de incorporação do $\mathrm{Fe}$ na superfície da celulose $(25 \%$ em peso). Os resultados de caracterização indicaram que as fibras de celulose podem suportar partículas de óxido de ferro; enquanto que os testes de eficiência e lixiviação do material apontou características complementares para um modelo estrutural do compósito de celuloseferro.

\subsection{Hidróxido de magnésio}

O hidróxido de magnésio é uma base fraca, cuja fórmula molecular é $\mathrm{Mg}(\mathrm{OH})_{2}$. Segundo as informações contidas na sua ficha de informações de segurança de produtos químicos (FISPQ), é um sólido branco, não perigoso, inodoro, pouco solúvel em água, que se decompõem termicamente em temperaturas superiores a $350^{\circ} \mathrm{C}$. Pode ser obtido por meio da reação de sulfato de magnésio com solução aquosa de hidróxido de sódio, pela reação de sais de magnésio com hidróxido de potássio ou de amônio, ou ainda pela reação da água com o óxido de magnésio. $O$ hidróxido de magnésio, também conhecido como brucita tem estrutura hexagonal e densidade de $2,4 \mathrm{~g} / \mathrm{cm}^{3}$, durante a reação de hidratação, pode-se observar uma expansão de volume três vezes maior do inicial. Sendo esta última reação um fator limitante no uso do óxido de 
magnésio em refratários devido à menor densidade do hidróxido causar tensões destrutivas nesses materiais.

Hidróxidos inorgânicos influenciam nas propriedades finais dos materiais híbridos, reduzindo a adsorção de umidade, conferindo propriedades como condutividade elétrica, paramagnetismo ou ainda alterando sua estabilidade térmica, como é o caso do hidróxido de magnésio (Hao; Xiao-Bai \& Xiao-Lu, 2013; Rothon \& Hornsby, 1996). A decomposição do hidróxido de magnésio é um processo endotérmico, que envolve considerável quantidade de energia, cerca de $1450 \mathrm{~J} / \mathrm{g}$. Com a incorporação do $\mathrm{Mg}(\mathrm{OH})_{2}$ em uma matriz orgânica, o processo de degradação do material híbrido é inibido até que a energia do sistema seja suficiente para decompor todo o hidróxido presente. Com isso, o $\mathrm{Mg}(\mathrm{OH})_{2}$ apresenta propriedades retardante de chama (Rothon \& Hornsby, 1996).

Ding e colaboradores (2001), apresentaram em seus estudos o resultado de uma análise termogravimétrica, realizada com uma amostra de $\mathrm{Mg}(\mathrm{OH})_{2}$, submetida a um aquecimento que foi de 20 a $1000^{\circ} \mathrm{C}$. A figura 5 apresenta o gráfico representativo deste ensaio.

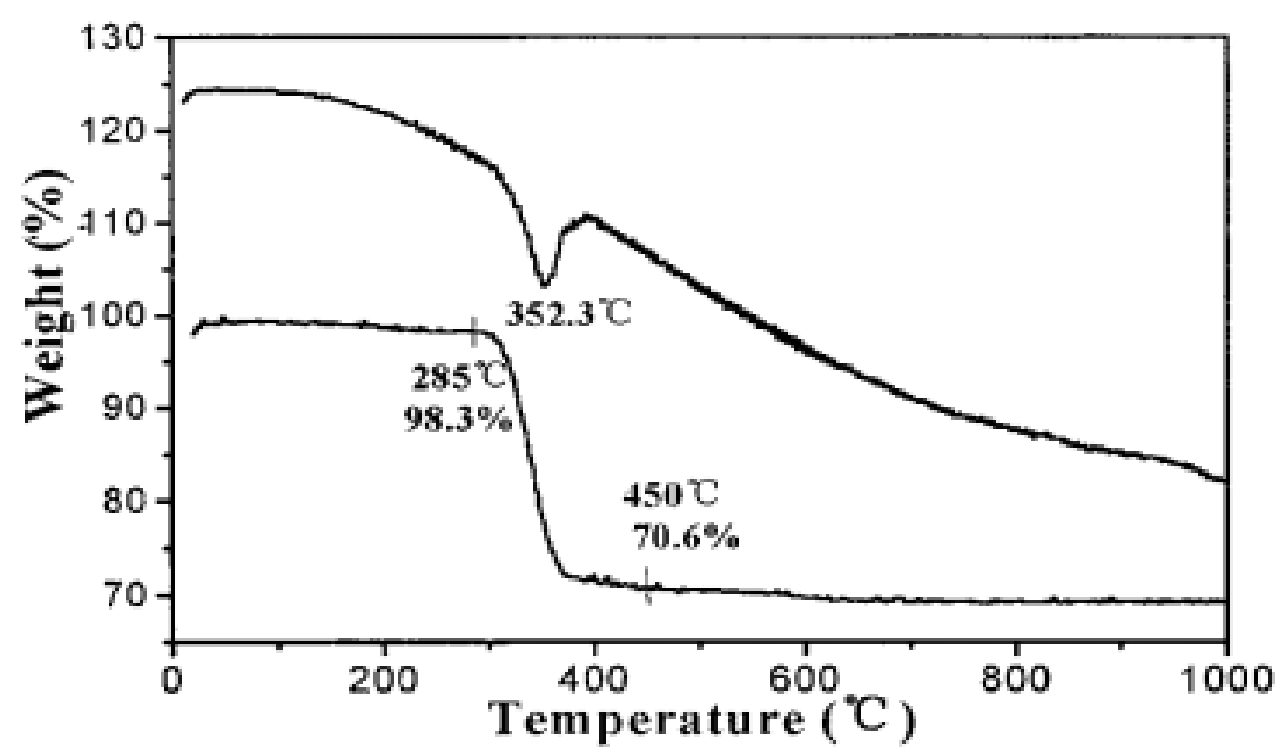

Figura 5: Ensaio termogravimétrico da calcinação do $\mathrm{Mg}(\mathrm{OH})_{2}$ com fluxo de $\mathrm{N}_{2}$, (Ding et al., 2001, p. 439) 
A partir do gráfico da figura 5 , verifica-se que a perda de massa se deu no intervalo entre 285 e $450^{\circ} \mathrm{C}$, o que de acordo com os pesquisadores do trabalho é conciliável com demais resultados apresentados na literatura. A outra curva retrata a energia absorvida pelo sistema reacional, mostrando um pico endotérmico em $352,3^{\circ} \mathrm{C}$.

Como principais aplicações do hidróxido de magnésio, pode-se citar seu uso na indústria de papel e celulose, no processamento de urânio e no refino de açúcar. Entretanto, esse composto é amplamente utilizado na indústria de plástico e de espuma por atuar como agente retardante de chama, tendo a função de reduzir a possibilidade de combustão dos materiais poliméricos. Além disso, esse hidróxido vem sendo considerado uma boa opção de aditivo nos materiais plásticos por apresentar baixo custo e baixa toxidade, decorrente da não liberação de gases tóxicos ou substâncias corrosivas durante a queima, agindo simultaneamente como retardante de chama e supressor de fumaça (Visconde \& Nunes, 2001). Possuindo essa propriedade por se decompor endotermicamente com liberação de água, em temperaturas próximas a temperatura de degradação do material polimérico, conforme a reação apresentada a seguir:

$$
\mathrm{Mg}(\mathrm{OH})_{2} \rightarrow \mathrm{MgO}+\mathrm{H}_{2} \mathrm{O}
$$

Os hidróxidos são amplamente utilizados em processos de desacidificação. Partículas alcalinas em nanoescalas, aplicadas através de dispersões não-aquosas, são eficientes para a preservação de materiais celulósicos, cuja deterioração por despolimerização é catalisada pela presença de espécies ácidas. Nanopartículas de $\mathrm{Ca}(\mathrm{OH})_{2}$ e $\mathrm{Mg}(\mathrm{OH})_{2}$ são compatíveis com esses suportes, possuem superior penetrabilidade $\mathrm{e}$ devido a elevada área superficial específica, neutralizam muito a acidez do papel (Baglioni et al., 2013; Baglioni \& Giorgi, 2006; Giorgi et al., 2002). 


\subsubsection{Os compósitos com hidróxido de magnésio}

O processo de combustão configura-se em riscos à saúde e à vida humana. A busca por materiais que dispõem de estabilidade química enquanto esse processo ocorre ou que prorroguem o início da combustão são objetos de pesquisa na área de ciência e engenharia. Estas são direcionadas para procura de materiais com propriedades retardantes de chamas enquanto expostos ao risco de incineração, tornando o ambiente mais seguro contra incêndios (Martins et al., 2011). Trabalhos estão sendo desenvolvidos com a finalidade de alcançar aditivos para materiais poliméricos, como retardantes de chama (Laoutid et al., 2009; Lu \& Hamerton, 2002; Zang \& Horrocks, 2003). No que diz respeito aos principais retardantes de chama para materiais poliméricos têm-se os produtos aromáticos, halogenados ou compostos de metais pesados. A utilização destes aditivos eleva a toxicidade dos produtos formados durante a combustão (Zang \& Horrocks, 2003). De acordo com Matos et al., (2002) o hidróxido de magnésio reúne todas as características necessárias para ser utilizado como retardante de chama e pode ser preparado sinteticamente com confiável grau de pureza e múltiplas morfologias relevantes, já que este responde bem as modificações da superfície.

A brucita $\mathrm{Mg}(\mathrm{OH})_{2}$ decompõe-se endotermicamente com liberação de água a temperaturas próximas àquelas de degradação de polímeros, as quais são suficientemente altas $\left(300-320^{\circ} \mathrm{C}\right)$ para permitir a incorporação em diversos tipos de polímeros inclusive nos de formulações de plásticos. Nesse sentido Matos e colaboradores (2002) estudaram a aplicação do $\mathrm{Mg}(\mathrm{OH})_{2}$ preparado por meio da carnalita $\left(\mathrm{KCl} \cdot \mathrm{MgCl}_{2} \cdot 6 \mathrm{H}_{2} \mathrm{O}\right)$, fazendo assim o controle morfológico, em polimetilmetacrilato (PMMA) e investigaram a degradação térmica do polímero incorporado a este enchimento inorgânico. Os resultados indicaram efeitos significativos de retardamento de chama por parte do $\mathrm{Mg}(\mathrm{OH})_{2}$, que já são esperados pelos estudos mas apenas para porcentagens em massa acima de $60 \%$. No entanto o diferencial foi que eles identificaram resultados favoráveis para metade desta porcentagem. 
Martins et al., (2011) avaliaram a eficácia do hidróxido de alumínio e do hidróxido de magnésio como aditivos retardantes de chama em polipropileno com o acréscimo de fibras de vidro neste compósito. O objetivo deste acréscimo foi dificultar 0 amolecimento do material polimérico, havendo assim tempo para a formação de uma película inibidora de oxigênio, retardando a propagação da chama. $O$ comportamento basilar de um retardante de chamas respalda-se em interferir quimicamente no mecanismo de propagação da chama. Esse processo pode transcorrer por meio da geração de gases incombustíveis que arrefecem o suprimento de $\mathrm{O}_{2}$ ou formando uma camada protetora que diminui a superfície de contato do combustível com o comburente. Os resultados obtidos por esse estudo validam que hidróxidos de magnésio e alumínio podem ser utilizados como retardantes de chama em conjunto com as fibras de vidro. Confrontada a retardância de chama em corpos de prova somente com hidróxidos e corpos de prova com hidróxidos e fibra de vidro, notou-se uma maior retardância à chama. No entanto o material ainda não alcance a classificação $\mathrm{V} 0, \mathrm{o}$ que significa dizer que $\mathrm{o}$ composto polimérico não goteja e extingue a chama.

A decomposição térmica de um nanocompósito foi estudada por Jalajerdi et al., (2015). Eles avaliaram o efeito do dodecil sulfonato de sódio (SDS como surfactante aniônico) e do brometo de cetil-tri-metilamônio (CTAB como surfactante catiônico) na morfologia de nanoestruturas de hidróxido de magnésio que foram sintetizadas por uma rápida reação de micro-ondas. Estas nanopartículas modificadas foram então adicionadas à matriz de acetato de celulose. Foi verificado que a decomposição térmica dos nanocompósitos mudam para temperatura mais alta na presença de nanoestruturas de $\mathrm{Mg}(\mathrm{OH})_{2}$. Segundo os autores o aumento da estabilidade térmica dos nanocompósitos se deu devido à decomposição endotérmica do $\mathrm{Mg}(\mathrm{OH})_{2}$ e à liberação de água que dilui os gases combustíveis.

O envelhecimento e a proteção do papel são de interesse crucial para melhorar a preservação das coleções e arquivos das bibliotecas. Nesse contexto, Sierra-Fernandez e colaboradores (2016) investigaram a influência de nanopartículas de $\mathrm{Mg}(\mathrm{OH})_{2}$ nas propriedades de diversos 
tipos de folhas de celulose a fim de constatar se os efeitos observados se faziam dependentes da morfologia inicial. Folhas de fibra de celulose altamente resistentes ao envelhecimento foram obtidas por tratamento com nanopartículas de hidróxido de magnésio $\left(\mathrm{Mg}(\mathrm{OH})_{2}\right)$. Os resultados mostraram que as folhas feitas da mistura de fibras apontavam um índice maior de tensão e suavidade. A modificação alcançada com as nanopartículas de $\mathrm{Mg}(\mathrm{OH})_{2}$ induziu um aumento no $\mathrm{pH}$ das folhas para valores ligeiramente básicos (cerca de pH 8.0), o que facilita a ligação entre as fibras e aumenta a suavidade das folhas. Ao expor as folhas ao envelhecimento artificial acelerado termo-higrométrico, foi verificado que as propriedades físicas das folhas tratadas não eram significativamente dependentes dos fatores ambientais. As conclusões gerais evidenciaram que o grau de refino da celulose desempenhou um papel importante no tratamento dos compósitos celulósicos com nanopartículas de hidróxido magnésio. Logo, o tratamento das folhas de papel folhas com nanopartículas de $\mathrm{Mg}(\mathrm{OH})_{2}$ podem ser uma boa abordagem para a proteção dos documentos em suporte de papel contra o envelhecimento.

\section{5. Óxidos como catalisadores}

Segundo Dias, et al., (2012), a catálise é um processo no qual a velocidade de uma reação é influenciada pela adição de uma substância química para diminuir a barreira de ativação (energia de ativação) e assim alterar o mecanismo de reação, provendo uma alternativa de reação, contendo energia de ativação menor que o caminho convencional.

Os catalisadores possibilitam que as reações ocorram com maior velocidade e em temperaturas mais baixas. Para Busacca et al., (2011), os catalisadores devem ser utilizados em proporções mínimas e serem recuperados intactos ao final da reação. Nesse sentido Bernardo-Gusmão et al., (2017) conceitua um catalisador como uma substância química que, adicionada em pequenas quantidades, acelera uma reação química sem por ela ser intrinsecamente consumido. A catálise é de vital importância para a indústria química, em torno de $80 \%$ dos produtos químicos industriais se submetem a um processo catalítico em pelo menos uma 
etapa de sua fabricação. A catálise se configura em uma etapa importante para os setores de refino de petróleo, petroquímica, polímeros, agroquímicos, aromas e fragrâncias e fármacos.

Yuryev et al., (2010) classificam a catálise como: homogênea, heterogênea, biocatálise e organocatálise, cada uma com suas especificidades, propriedades e aplicabilidades.

De acordo com Dias et al., (2012), os processos catalíticos são de vital importância para o crescimento de uma sociedade sustentável. Os processos catalíticos tendem a seguir caminhos que conduzem a uma química viável, na qual ocorre a produção de compostos seletivos, ativos e estáveis, com menor dispêndio de energia e de combustível de forma eficiente e não agressiva ao meio ambiente, simultaneamente. Há uma diversidade de produtos que podem ser obtidos por processos catalíticos, incluindo alimentos, medicamentos, combustíveis, polímeros, fragrâncias, dentre outros. Configura-se desafios dos processos catalíticos apresentarem menor custo e quantidades de rejeitos, com melhores rendimentos, e com condições suaves de temperatura e pressão. Superar esses desafios é fomentar uma sociedade sustentável. Devido às pressões sociais e governamentais em busca de processos mais limpos, a introdução de novos processos industriais baseados em catálise tende a ser mais incentivados nos próximos anos (Gusmão et al., 2017).

De acordo com Araújo (2011) os óxidos exercem papel fundamental em diversos campos de atuação, como na ciência dos materiais e na catálise. Contudo, destaca-se seu comportamento no que tange à catálise química. A indústria voltada para essa área produz um número muito expressivo de catalisadores à base de óxidos tipo bulk, que funcionam como suportes ou que estejam suportados (Fernández-García et al., 2004). Uma dispersão homogênea e o controle do tamanho das partículas de tais óxidos, se fazem necessários, haja vista que em muitos processos as reações são relativamente dependentes da estrutura e podem ser influenciadas conforme o tamanho do cristalito do catalisador (Rojas et al., 2004). De acordo com Cuenya (2010) outros fatores como a geometria, o estado de oxidação e a composição podem também interferir na reatividade das fases ativas nos materiais. 
Óxidos inorgânicos têm sido amplamente investigados como catalisadores para produção de biodiesel, sendo comum o uso de óxidos simples ou mistos, que podem ser obtidos pela calcinação de um sal na presença do óxido de interesse ou utilizando de fontes comerciais (Cordeiro et al., 2011). A produção do biodisel é comumente realizada por meio da reação de transesterificação por catálise homogênea. Cintra e colaboradores (2016) estudaram a influência da variável "tempo de reação" no rendimento em biodiesel através da reação de transesterificação metanólica do óleo de soja refinado em presença do catalisador heterogêneo óxido de cálcio $(\mathrm{CaO})$. O estudo teve resultados satisfatórios porquanto o biodiesel sintetizado com óleo de soja nas condições fixas de temperatura de $65^{\circ} \mathrm{C}$, razão molar álcool/óleo de 12:1, $8 \%$ em peso de catalisador básico apontou um rendimento maior ( 95\%) após duas horas de reação, quando comparado aos demais tempos considerados na pesquisa.

Kouzu et al., (2008) avaliaram os catalisadores de cálcio na forma de óxido $(\mathrm{CaO})$, hidróxido $\left(\mathrm{Ca}(\mathrm{OH})_{2}\right)$ e carbonato $\left(\mathrm{CaCO}_{3}\right)$ na reação de transesterificação do óleo de soja refinado e óleo de cozinha processado, aplicando o metanol como solvente em excesso. A fim de obter parâmetros para comparação foram avaliados ainda os catalisadores de óxidos de metais alcalino terrosos $\mathrm{MgO}$ e $\mathrm{SrO}$. Segundo os resultados dos pesquisadores, o rendimento em ésteres metílicos na transesterificação do óleo de soja, indicou uma atividade catalítica na seguinte sequência: $\mathrm{MgO}<<\mathrm{CaO}<<\mathrm{SrO}$. Quando usado como catalisador heterogêneo na transesterificação do óleo de soja o $\mathrm{CaO}$, obteve-se rendimentos acima de $99 \%$ em ésteres metílicos, nas respectivas condições: $0,8 \%$ em peso de $\mathrm{CaO}$, razão molar álcool/óleo de 12:1 e tempo de reação de 2 horas.

Guaglianoni e colaboradores (2015) investigaram atividade fotocatalítica do óxido de zinco nanoestruturado sintetizado por combustão em solução (SCS), via rota de nitrato de zinco e ácido cítrico. A atividade catalítica foi avaliada por meio da degradação de uma solução de alaranjado de metila. Segundo os autores os resultados obtidos indicaram que os pós de $\mathrm{ZnO}$ sintetizados com menores proporções combustível/oxidante apresentaram picos mais intensos nos padrões de 
DRX e maiores tamanhos de cristalitos. Esses variaram entre 9,2 a 41,6 nm. A análise térmica indicou perda de massa em função da estequiometria dos reagentes, mostrando-se maiores quando se tratava de reações com excesso de combustível, o que sugere ser referente à queima do material orgânico remanescente. As formulações com maior cristalinidade apresentaram superior desempenho fotocatalítico. A matéria orgânica contidas nas amostras que possuíam maior razão molar combustível/oxidante interferiu na degradação do alaranjado de metila. Posterior ao tratamento térmico, essas amostras tiveram sua atividade fotocatalítica melhorada.

Pütün (2010) realizou um estudo com as sementes de algodão, sendo usadas como fonte de biomassa, pirolisadas em um reator tubular de leito fixo sob vários gases de varrimento $\left(\mathrm{N}_{2}\right)$ a diferentes temperaturas. No trabalho não catalítico, o rendimento máximo de bioóleo foi atingido como $48,30 \%$ a $550^{\circ} \mathrm{C}$. Nas condições ótimas, a pirólise catalítica de amostras de biomassa foi realizada com várias quantidades de catalisador de $\mathrm{MgO}$ (5, 10, 15 e $20 \%$ em peso da matéria prima). A adição de catalisador diminuiu a quantidade de bio-óleo, mas aumentou a qualidade do bio-óleo em termos de poder calorífico, distribuição de hidrocarbonetos e remoção de grupos. Observou-se que o aumento da quantidade de catalisador utilizado diminuiu o rendimento do óleo, mas aumentou os rendimentos de gás e carvão.

Nesse sentido Araújo (2011) fez a síntese e a caracterização do óxido de magnésio por diferentes técnicas e estudou sua aplicação na produção de biodiesel. Ele concluiu que de um modo geral, todas as reações analisadas tiveram altas conversões, chegando a um valor de 99,01\% para a amostra de MgO da síntese hidrotérmica. 


\section{Metodologia}

O delineamento metodológico do trabalho apresentado se dará por meio da descrição dos reagentes utilizados, dos procedimentos adotados (que foram definidos a partir de informações e resultados analisados na revisão bibliográfica) para a preparação das matérias primas, seguido pela obtenção das amostras estudadas. Por fim do detalhamento dos métodos e técnicas utilizados para a caracterização e avaliação dos referidos materiais.

\subsection{Materiais}

Matriz: Alfa-celulose (Sigma-Aldrich Brasil Ltda., Cotia/SP - Brasil);

Agente precursor: Álcool Polivinílico P.S. $\left(\mathrm{C}_{2} \mathrm{H}_{4} \mathrm{O}\right) \mathrm{n}$ (Sigma-Aldrich Brasil Ltda., Duque de Caxias/RJ - Brasil);

Reagentes: Hidróxido de sódio lentilhas $(\mathrm{NaOH})$ P.A. (SigmaAldrich Brasil Ltda., Duque de Caxias/RJ - Brasil); Ácido clorídrico P.A. (Pró-químios LTDA., Rio de Janeiro/RJ - Brasil); Nitrato de Magnésio Hexahidratado P.A. $\left(\mathrm{MgNO}_{3}\right)_{2}$ (Vetec Química Fina LTDA., Duque de Caxias/RJ -Brasil);

Consumíveis: Papel de filtro quantitativo para filtração fina (ISOFAR ®); Membranas lisas AC 047mm 0,45 $\mu$ (UNIFIL); Grades Lacey F/C 300 mesh Cu (TED PELLA INC USA).

A mensuração de $\mathrm{pH}$ durante a síntese das amostras, foi realizada por meio do pHmetro de marca MS TECNOPON®, modelo mPA210, pertencente ao Laboratório de Análises Químicas do Departamento de Engenharia Química e de Materiais da PUC-Rio. 


\subsection{Métodos}

\subsubsection{Síntese das matérias primas}

\subsubsection{Preparação e calcinação preliminar do hidróxido pela rota do nitrato}

Nesta fase o hidróxido de magnésio foi sintetizado por alcalinização de solução aquosa do nitrato de magnésio. Esse procedimento teve como base o artigo de Phillipp \& Fujimoto (1992).

As reações químicas esperadas são conforme representadas abaixo:

$\mathrm{Mg}\left(\mathrm{NO}_{3}\right)_{2}(\mathrm{aq})+2 \mathrm{NaOH}(\mathrm{aq}) \rightarrow \mathrm{Mg}(\mathrm{OH})_{2}(\mathrm{~s})+2 \mathrm{NaNO}_{3}(\mathrm{aq})$

Seguem abaixo os procedimentos utilizados:

- Síntese do $\mathrm{Mg}(\mathrm{OH})_{2}$;

- Preparo da solução de $\mathrm{Mg}\left(\mathrm{NO}_{3}\right)_{2}$ - Dissolveu-se em um bécher de $1000 \mathrm{~mL}$ 6,5 g de $\mathrm{Mg}\left(\mathrm{NO}_{3}\right)_{2}$ em 100 mL de água deionizada;

- Preparo da solução de $\mathrm{NaOH} 1 \mathrm{M}$ - Foram dissolvidos 41,24 g de $\mathrm{NaOH}$ em água deionizada, utilizando-se um balão volumétrico de $1000 \mathrm{~mL}$;

- Precipitação do $\mathrm{Mg}(\mathrm{OH})_{2}$ - Para a precipitação montou-se um aparato experimental, com bureta de $50 \mathrm{~mL}$ para gotejamento da solução de $\mathrm{NaOH} 1 \mathrm{M}$ na solução de $\mathrm{Mg}\left(\mathrm{NO}_{3}\right)_{2}$ e o agitador magnético para homogeneizar a mistura;

$\mathrm{O}$ consumo de $\mathrm{NaOH} 1 \mathrm{M}$ foi calculado conforme a estequiometria da reação, considerando $20 \%$ de excesso, igual a $76 \mathrm{~mL}$;

Ao final da reação, o precipitado foi filtrado à vácuo em papel de filtro quantitativo para filtração fina. $O$ precipitado retido foi lavado com água deionizada, e seco em estufa por duas horas a $100^{\circ} \mathrm{C}$ houve um rendimento de 2,2 gramas, que foram maceradas manualmente no grau, acondicionada em recipientes próprios e armazenadas no dessecador. 
Para calcinação do material armazenado na etapa anterior, este material foi levado ao forno de mufla convencional, com controle digital de temperatura, sem atmosfera controlada, por 2 horas a $450^{\circ} \mathrm{C}$, conforme Ding et al., (2000), a fim de se obter o óxido de magnésio, este também foi identificado, acondicionado e armazenado no dessecador em embalagem própria para posterior utilização.

Para escolha do agente dispersante, era necessário um material com a densidade próxima à da celulose, a fim de que as fibras não precipitassem, nesse sentido. Alguns testes preliminares foram feitos com algumas soluções, como a água deionizada, o álcool isopropílico e o álcool polivinílico (PVA). Estes também foram testados no que se refere as suas concentrações respectivas. Por testes de observação foi escolhido o PVA.

\subsubsection{Preparação do agente precursor, álcool polivinílico}

Misturou-se o PVA 10\% w/w e água deionizada na proporção de 2 gramas de PVA para cada $100 \mathrm{~mL}$ de água dentro de um béquer de 500 $\mathrm{mL}$. Essa mistura foi aquecida a $60^{\circ} \mathrm{C}$, com agitação magnética constante, por duas horas, até obter-se um gel branco e viscoso. A figura 6, exibe a fase de preparação da solução PVA. 


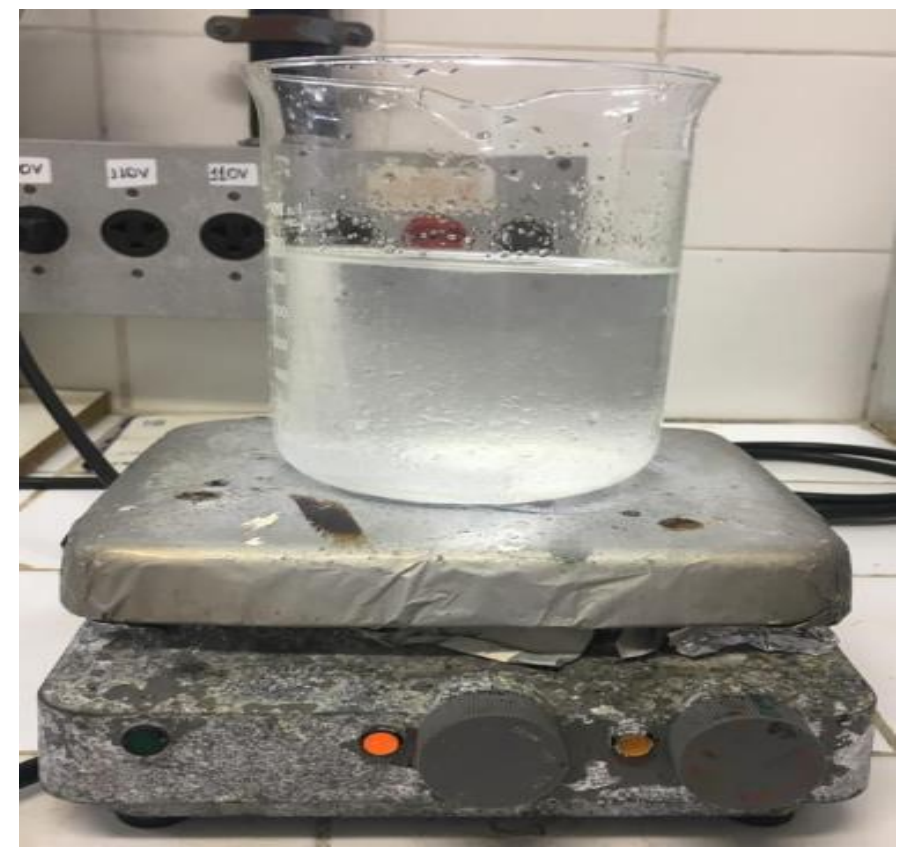

Figura 6: Preparação da solução PVA

\subsubsection{Testes de solubilidade}

Para avaliação preliminar da solubilidade do óxido de magnésio e do hidróxido de magnésio no PVA, foram feitas avaliações em temperatura ambiente e a $60^{\circ} \mathrm{C}$.

Teste I - em um béquer de $500 \mathrm{~mL}$, adicionou-se $100 \mathrm{~mL}$ de solução de PVA, 0,08 gramas de MgO em pó, juntamente com 4,5 mL de $\mathrm{HCl}$ e agitou-se por 2,5 horas. Em seguida foi realizada a filtragem a vácuo, o particulado retido na membrana fina foi levado ao forno por 45 minutos à temperatura de $100^{\circ} \mathrm{C}$, por conseguinte foi pesado o material que estava na membrana fina, percebendo-se então que não houve solubilidade total dessas partículas de $\mathrm{MgO}$ na solução de PVA.

Teste II - em um béquer de $500 \mathrm{~mL}$, adicionou-se $100 \mathrm{~mL}$ de solução de PVA, 0,4 gramas de MgO em pó, juntamente com 22,5 ml de $\mathrm{HCl}$ e agitou-se por 2,5 horas. Em seguida foi realizada a filtragem a vácuo, o particulado retido na membrana fina foi levado ao forno por 45 minutos à temperatura de $100^{\circ} \mathrm{C}$, por conseguinte foi pesado o material que estava na membrana fina, percebendo-se então que não houve solubilidade total dessas partículas de MgO na solução de PVA. 
Teste III - em um béquer de $500 \mathrm{~mL}$, adicionou-se $100 \mathrm{~mL}$ de solução de PVA, 0,08 gramas de $\mathrm{Mg}(\mathrm{OH})_{2}$ em pó, juntamente com 4,5 mL de $\mathrm{HCl}$ e agitou-se por 2,5 horas. Em seguida foi realizada a filtragem a vácuo, o particulado retido na membrana fina levado ao forno por 45 minutos à temperatura de $100^{\circ} \mathrm{C}$, por conseguinte foi pesado o material que estava $n$ na membrana fina, percebendo-se então que não houve solubilidade total dessas partículas de $\mathrm{Mg}(\mathrm{OH})_{2}$ na solução de PVA.

Teste IV - em um béquer de $500 \mathrm{~mL}$, adicionou-se $100 \mathrm{~mL}$ de solução de PVA, 0,4 gramas de $\mathrm{Mg}(\mathrm{OH})_{2}$ em pó, juntamente com 22,5 ml de $\mathrm{HCl}$ e agitou-se por 2,5 horas. Em seguida foi realizada a filtragem a vácuo, o particulado retido na membrana fina levado ao forno por 45 minutos à temperatura de $100^{\circ} \mathrm{C}$, por conseguinte foi pesado o material que estava na membrana fina, percebendo-se então que não houve solubilidade total dessas partículas de $\mathrm{Mg}(\mathrm{OH})_{2}$ na solução de PVA.

Os testes de I a IV foram realizados sob duas condições: temperatura ambiente e a $60^{\circ} \mathrm{C}$, mantendo todas as demais condições e proporções, e pôde-se observar que embora o material remanescente na membrana tenha diminuído em comparação com os testes em temperatura ambiente, ainda era visível a retenção de algumas partículas. Os resultados quantitativos estão expostos em item próprio dos resultados.

\subsubsection{Síntese das amostras de fibras de celulose tratada com hidróxido de magnésio e das amostras maceradas com óxido de magnésio:}

\section{Amostra I}

Para obtenção da amostra I, em um béquer de $500 \mathrm{~mL}$ foi adicionado $100 \mathrm{~mL}$ de solução de PVA, em seguida acrescentou-se $4 \mathrm{~g}$ de celulose, após sua completa imersão na solução. Foi realizado o aferimento do $\mathrm{pH}$ que se encontrava em 5.6. Gradativamente foi adicionando-se 0,08 gramas de $\mathrm{Mg}(\mathrm{OH})_{2}$ (o que representa 2\% em massa tendo como base a celulose) e concomitantemente $4,5 \mathrm{~mL}$ de solução de $\mathrm{HCl}$ (concentração $5 \%$ ), a qual foi gotejada até que o pH se estabilizasse no valor 6.0. A agitação magnética foi constante durante todo o 
procedimento. Em seguida a solução foi filtrada a vácuo em papel de filtro quantitativo para filtração fina, o aparato utilizado para filtragem a vácuo das amostras pode ser visto na figura 7 , então o material retido no filtro foi lavado com água deionizada e seco em estufa a $100^{\circ} \mathrm{C}$ por 45 minutos, acondicionado em recipiente fechado, intitulado como Amostra I e armazenada no dessecador. Na figura 8 , tem-se a amostra I posterior a filtração da solução (a), depois de sair do forno mufla a $100^{\circ} \mathrm{C}$ por 45 minutos (b) e após ser extraída do papel filtro (c). E na figura 9 tem-se uma representação do processo de síntese da amostra I.

Para obtenção da amostra II seguiu-se as mesmas etapas da síntese descrita acima para amostra I, exceto que foi adicionado 0,4 gramas de $\mathrm{Mg}(\mathrm{OH})_{2} \quad$ (10\% em relação à massa da celulose) e para estabilizar o pH em 6.0 foi necessário $22,5 \mathrm{~mL}$ de solução de $\mathrm{HCl}(5 \%$ de concentração), a qual foi gotejada à medida que o pH aumentava para que se alcançasse a estabilização do mesmo. Esta foi intitulada como amostra II e armazenada no dessecador.

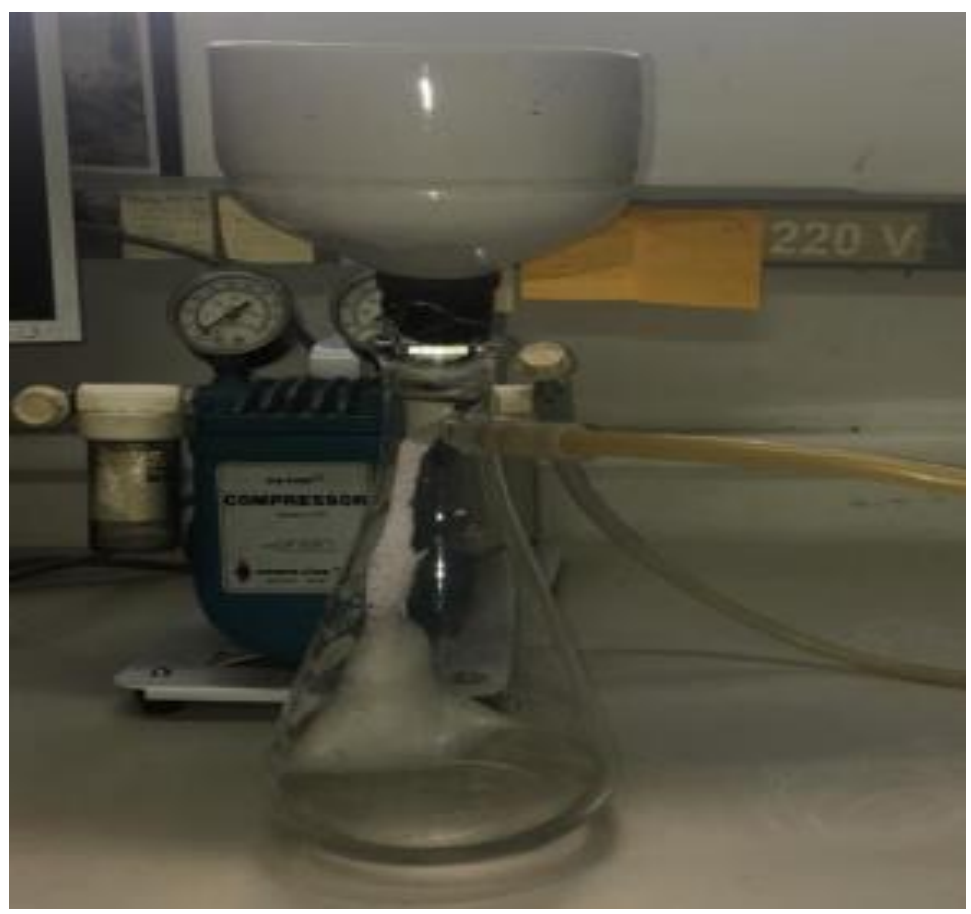

Figura 7: Aparato utilizado para filtragem a vácuo das amostras 


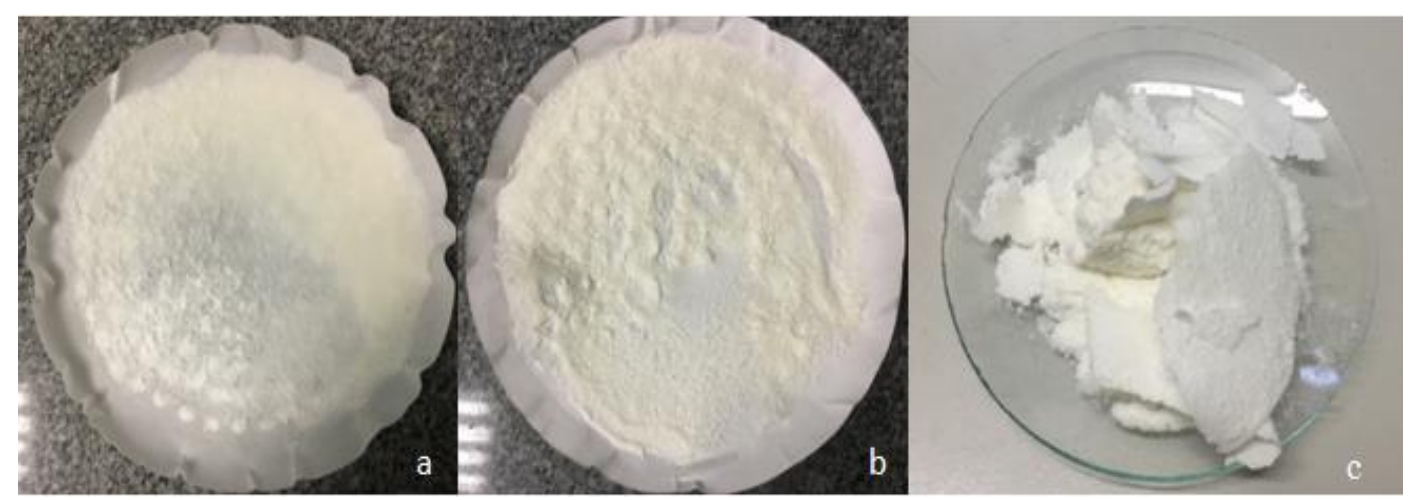

Figura 8: Amostra I depois de ser filtrada (a), depois de sair do forno de mufla a $100^{\circ} \mathrm{C}$ por 45 minutos (b) e após ser extraída do papel filtro (c).

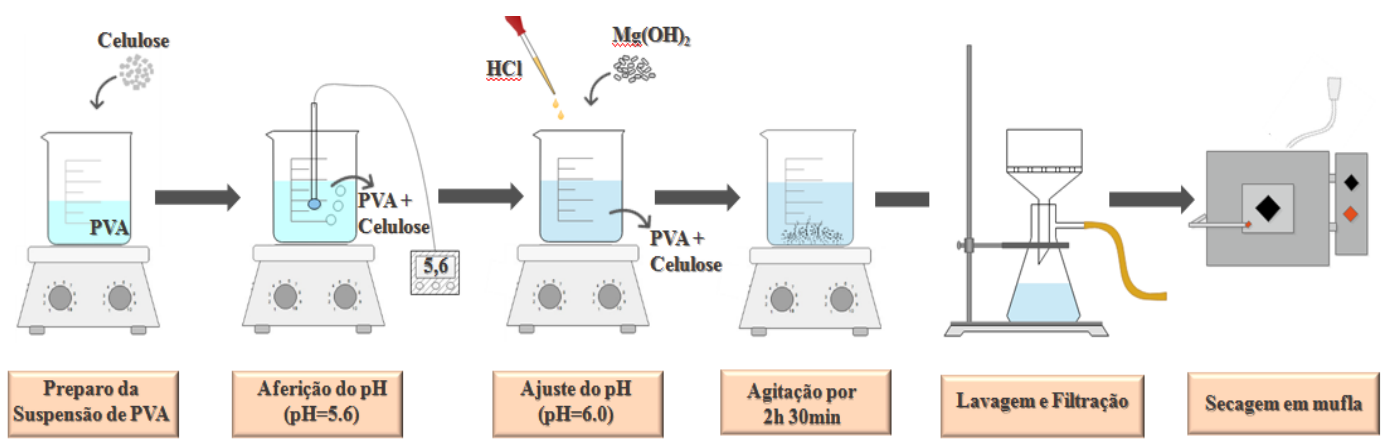

Figura 9: Representação do processo de síntese da amostra I.

- Amostras com solução de $\mathrm{Mg}(\mathrm{OH})_{2}$

Para obtenção das amostras III (sol.) e IV (sol.), foi empregado o hidróxido de magnésio $\left(\mathrm{Mg}(\mathrm{OH})_{2}\right)$ em solução ao invés de usá-lo em pó, então o PVA usado na síntese foi preparado com proporções menores de água deionizada, a fim de descontar a quantidade de água que já entraria no processo da síntese das amostras por meio da solução de hidróxido. Assim para a amostra III (sol), a solução de preparação do agente precursor, álcool polivinílico, foi usado $2 \mathrm{~g}$ de PVA (pó) para cada 93,38 $\mathrm{mL}$ de água deionizada. Essa mistura foi colocada em béquer de $500 \mathrm{~mL}$, aquecida a $60^{\circ} \mathrm{C}$, com agitação magnética, por duas horas, até obter-se um gel branco com viscosidade aparente. Então para a síntese da amostra III (sol.) seguiu as seguintes etapas: em um béquer de $500 \mathrm{ml}$ foi adicionado 93,38 mL de solução de PVA, em seguida acrescentou-se $4 \mathrm{~g}$ de celulose, após sua completa imersão na solução, foi realizado o 
aferimento do $\mathrm{pH}$ que se encontrava em 5.6, então gradativamente foi adicionando-se $6,7 \mathrm{~mL}$ da solução de hidróxido de magnésio, o que seria correspondente a 0,08 gramas de $\mathrm{Mg}(\mathrm{OH})_{2}$ em pó (o que representa $2 \%$ em massa tendo como base a celulose) e concomitantemente $4,5 \mathrm{~mL}$ de solução de $\mathrm{HCl}$ ( $5 \%$ de concentração) foi gotejado até que $\mathrm{opH}$ se estabilizasse no valor 6.0. A agitação magnética foi constante durante todo o procedimento. Em seguida a solução foi filtrada à vácuo em papel de filtro quantitativo para filtração fina, assim o material retido no filtro foi lavado com água deionizada e seco em estufa a $100^{\circ} \mathrm{C}$ por 45 minutos, acondicionado em recipiente fechado, intitulado como amostra III (sol) e armazenada no dessecador.

Para síntese da amostra IV (sol.) foi necessária uma preparação diferenciada da solução do agente precursor, PVA. Nesse caso, foi usado $2 \mathrm{~g}$ de PVA para cada $67 \mathrm{~mL}$ de água deionizada. Essa mistura foi colocada em béquer de $500 \mathrm{~mL}$, aquecida a $60^{\circ} \mathrm{C}$, com agitação magnética, por duas horas, até obter-se um gel branco com viscosidade aparente. Então seguiu as seguintes etapas, num béquer de $500 \mathrm{~mL}$ foi adicionado $67 \mathrm{~mL}$ da solução de PVA, em seguida acrescentou-se $4 \mathrm{~g}$ de celulose, após sua completa imersão na solução, foi realizado o aferimento do $\mathrm{pH}$ que se encontrava em 5.6, então gradativamente foi adicionando-se $33 \mathrm{~mL}$ da solução de hidróxido de magnésio, o que seria correspondente à $0,4 \mathrm{~g}$ de $\mathrm{Mg}(\mathrm{OH})_{2}$ em pó (o que representa $10 \%$ em massa tendo como base a celulose) e concomitantemente $22,5 \mathrm{~mL}$ de solução de $\mathrm{HCl}$ ( $5 \%$ de concentração) foi gotejado até que $0 \mathrm{pH}$ se estabilizasse no valor 6.0. A agitação magnética foi constante durante todo o procedimento. Em seguida a solução foi filtrada à vácuo em papel de filtro quantitativo para filtração fina, então o material retido no filtro foi lavado com água deionizada e seco em estufa a $100^{\circ} \mathrm{C}$ por 45 minutos, acondicionado em recipiente fechado, intitulado como amostra IV (sol) e armazenado no dessecador. 
- Amostras com $\mathrm{Mg}(\mathrm{OH})_{2}$ dissolvidos a $60^{\circ} \mathrm{C}$

Para síntese da amostra $V$ foi empregada a metodologia que segue. Neste caso, foi usado 2 gramas de PVA para cada $100 \mathrm{~mL}$ de água deionizada. Essa mistura foi colocada em béquer de $500 \mathrm{~mL}$, aquecida a $60^{\circ} \mathrm{C}$, com agitação magnética, por duas horas, até obter-se um gel branco com viscosidade aparente.

Então seguiu as seguintes etapas para síntese do material, num béquer de $500 \mathrm{~mL}$ foi adicionado $100 \mathrm{~mL}$ de solução de PVA, em seguida adicionou-se $0,09 \mathrm{~g}$ de $\mathrm{Mg}(\mathrm{OH})_{2}$ em pó, em agitação magnética constante por 1,5 horas a $60^{\circ} \mathrm{C}$. Foi gotejado $5,1 \mathrm{~mL}$ de $\mathrm{HCl}$ até regular o $\mathrm{pH}$ em 6.0. Essa solução foi filtrada no aparato de filtro à vácuo por meio de uma membrana. Esperou-se o resfriamento da solução à temperatura ambiente, tornou a dispô-la em agitação magnética e inseriu $4 \mathrm{~g}$ de celulose gradativamente e após sua completa imersão na solução, foi realizado o aferimento do $\mathrm{pH}$ que se encontrava em 5.9.

Por fim a amostra foi filtrada a vácuo em papel de filtro quantitativo para filtração fina, o material retido no filtro foi lavado com água deionizada e seco em forno mufla à $100^{\circ} \mathrm{C}$ por 45 minutos, acondicionado em recipiente fechado, intitulada como amostra $V$ e armazenada no dessecador. O mesmo processo foi usado para $10 \%$ de $\mathrm{Mg}(\mathrm{OH})_{2}$ e a amostra intitulada como amostra VI (as respectivas variações de quantidades de materiais envolvidos na síntese tem como base a massa de celulose e o teste de solubilidade que tem seus resultados expostos na tabela 2 do item resultados).

- Amostra de celulose e óxido de magnésio (macerados a mão)

Em um grau de cerâmica, foi adicionado $4,0 \mathrm{~g}$ de celulose e $0,2 \mathrm{~g}$ de óxido de magnésio ( $5 \%$ em relação à massa da celulose) e macerado com auxílio de um pistilo, como demonstrado na figura 10. Essa mistura física foi realizada em 10 minutos, acondicionada, intitulada como a amostra macerada com 5\% de $\mathrm{MgO}$ e armazenada no dessecador. Outra amostra foi feita com essa mesma metodologia, porém com 10\% de óxido 
de magnésio em relação a massa de celulose e intitulada como amostra macerada com $10 \%$ de $\mathrm{MgO}$.

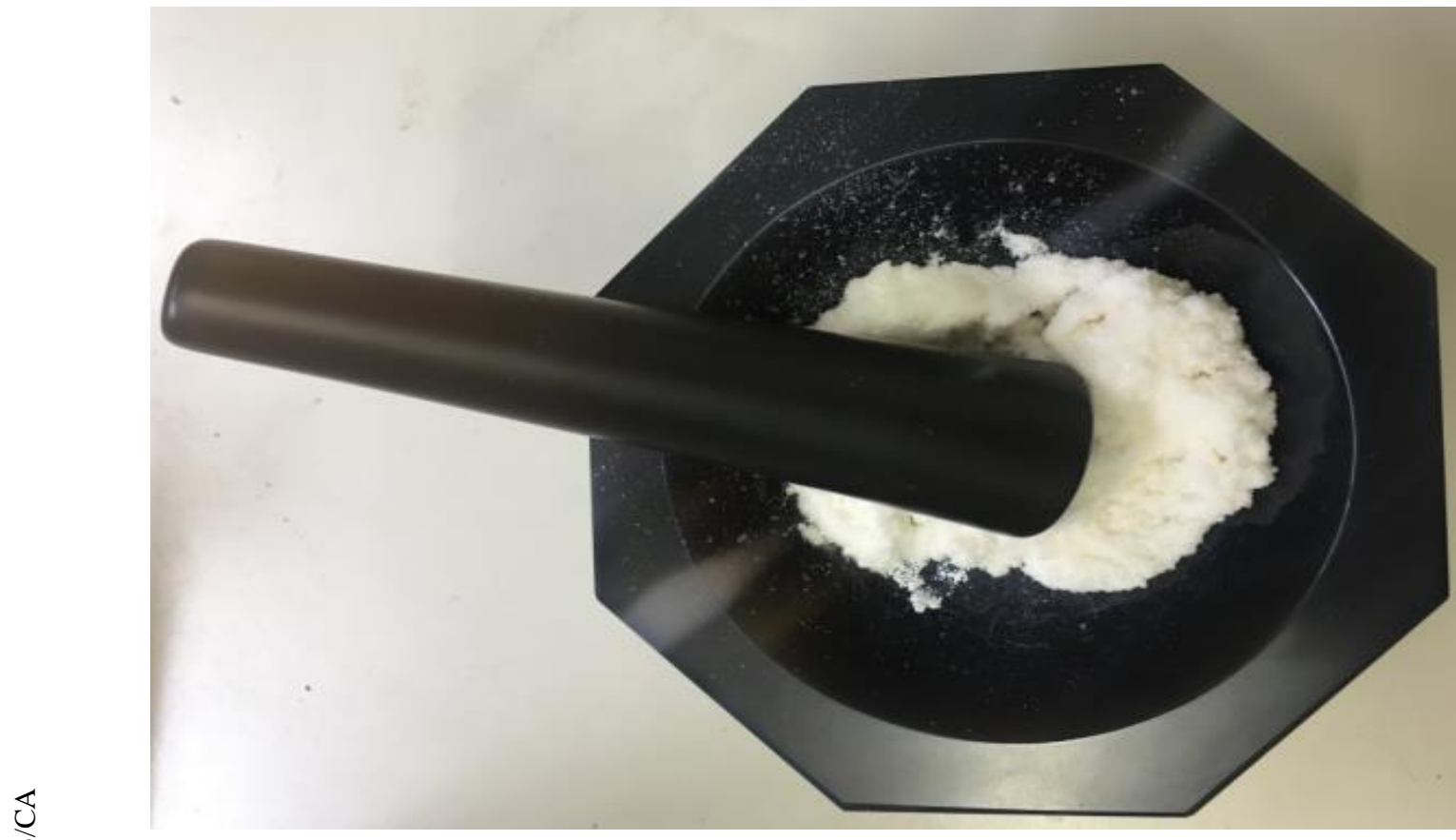

Figura 10: Síntese da amostra macerada (mistura física) celulose + óxido de magnésio

Na tabela 1 é possível identificar os elementos integrantes e as quantidades utilizadas em cada amostra. 
Tabela 1: Constituintes das amostras

\begin{tabular}{|c|c|}
\hline Identificação & Descrição \\
\hline Amostra I & $\begin{array}{l}4 \mathrm{~g} \text { de celulose }+100 \mathrm{~mL} \text { de PVA (sol.) + 0,08 g } \\
\text { de } \mathrm{Mg}(\mathrm{OH})_{2} \text { pó }+4,5 \mathrm{~mL} \mathrm{HCl} \text { (sol.) }\end{array}$ \\
\hline Amostra II & $\begin{array}{l}4 \mathrm{~g} \text { de celulose + } 100 \mathrm{~mL} \text { de PVA (sol.) + 0,4 g } \\
\text { de } \mathrm{Mg}(\mathrm{OH})_{2} \text { pó }+22,5 \mathrm{~mL} \mathrm{HCl} \text { (sol.) }\end{array}$ \\
\hline Amostra III (sol.) & $\begin{array}{l}4 \mathrm{~g} \text { de celulose }+93,3 \mathrm{~mL} \text { de PVA (sol.) }+6,7 \\
\mathrm{~mL} \text { de } \mathrm{Mg}(\mathrm{OH})_{2}+4,5 \mathrm{~mL} \mathrm{HCl} \text { (sol.) }\end{array}$ \\
\hline Amostra IV (sol.) & $\begin{array}{l}4 \mathrm{~g} \text { de celulose }+67 \mathrm{~mL} \text { de PVA (sol.) }+33 \mathrm{~mL} \\
\text { de } \mathrm{Mg}(\mathrm{OH})_{2}+22,5 \mathrm{~mL} \mathrm{HCl} \text { (sol.) }\end{array}$ \\
\hline Amostra V & $\begin{array}{l}4 \mathrm{~g} \text { de celulose }+100 \mathrm{~mL} \text { de PVA (sol.) + 0,09 g } \\
\text { de } \mathrm{Mg}(\mathrm{OH})_{2}+5,1 \mathrm{~mL} \mathrm{HCl} \text { (sol.) }\end{array}$ \\
\hline Amostra VI & $\begin{array}{l}4 \mathrm{~g} \text { de celulose }+100 \mathrm{~mL} \text { de PVA (sol.) + 0,43g } \\
\text { de } \mathrm{Mg}(\mathrm{OH})_{2}+24,1 \mathrm{~mL} \mathrm{HCl} \text { (sol.) }\end{array}$ \\
\hline $\begin{array}{l}\text { Amostra macerada } \\
\text { com } 5 \% \text { de } \mathrm{MgO}\end{array}$ & $4 \mathrm{~g}$ de celulose $+0,2 \mathrm{~g}$ de $\mathrm{MgO}$ \\
\hline $\begin{array}{l}\text { Amostra macerada } \\
\text { com } 10 \% \text { de } \mathrm{MgO}\end{array}$ & $4 \mathrm{~g}$ de celulose $+0,4 \mathrm{~g}$ de $\mathrm{MgO}$ \\
\hline
\end{tabular}

\subsubsection{Análises preliminares}

Para a execução de uma avaliação prévia das amostras, foram realizadas análises organolépticas. No que tange aos aspectos visuais, foram tomados os seguintes parâmetros e as respectivas escalas qualitativas:

Integridade das amostras:

- Quebradiças;

- Desagregadas;

- Deformadas;

- Coesas.

- Textura:

- Irregular; 
- Uniforme.

\subsubsection{Avaliação termodinâmica das reações}

Foram realizadas algumas simulações, com o intuito de obter informações no que tange ao comportamento termodinâmico dos materiais implicados nas reações.

\subsubsection{Decomposição térmica}

Foi utilizado o software HSC Chemistry versão 6, para avaliar as reações de decomposição térmica do hidróxido de magnésio e nitrato de magnésio envolvidos nos procedimentos experimentais empregados neste estudo. A simulação da decomposição térmica foi feita usando a atmosfera inerte de nitrogênio. O diagrama de especiação referentes às reações de acordo com a International Union of Pure and Applied Chemistry (IUPAC), consiste na distribuição de um elemento entre espécies químicas definidas em um sistema.

Ladeira e colaboradores (2014) também conceituaram como sendo a distribuição de diferentes espécies de um determinado elemento químico em uma amostra, considerando as espécies complexadas e não complexadas e a distinção entre os diferentes estados de oxidação. Dentre as finalidades da especiação química cabe ressaltar: a indicação das propriedades químicas e a reatividade de uma determinada substância ou metal. Nesse sentido, o estado de oxidação de um metal, o grau de protonação de um ácido ou a forma como um metal interage com os compostos presentes no meio ambiente aquático definem a especiação química (Ladeira et al., 2004).

\subsubsection{Caracterização das amostras}

Foi utilizado neste estudo um conjunto de técnicas de laboratório a fim de se caracterizar os materiais precursores e as amostras sintetizadas. 


\subsubsection{Difração de raios-X}

As análises de DRX foram realizadas no Laboratório de Difração de Raios-x do Departamento de Engenharia de Materiais Processos Químicos e Metalúrgicos da PUC-Rio. Foi utilizado um difratômetro de raios-x da marca BRUKER e modelo D8 Discover, com geometria de Bragg-Brentano, equipado com radiação CuKa $(1,5406 \AA)$ e filtro de níquel, com tubo de raios- $X$ com tensão de $40,0 \mathrm{kV}$ e corrente de $40 \mathrm{~mA}$. As varreduras foram feitas na região de ângulo $2 \theta$ de $10^{\circ}$ a $90^{\circ}$, com incremento de $0,02^{\circ}$ tempo por passo de $7 \mathrm{~s}$. Foi utilizado um portaamostra do tipo rotativo. Toda operação do equipamento é feita de forma automática.

Para o tratamento dos dados e geração dos difratogramas, utilizouse os softwares DIFFFRAC.EVA V.3, da Bruker e o DIFFRAC.TOPAS V.4.2. Mediante o uso do software DIFRFRAC.EVA V.3, da Brucker, as fases presentes na amostra foram identificadas. Este programa disponibiliza informações do banco de dados cristalográficos, o Crystallography Open Database (COD), e fornece informações que permitem a comparação entre os dados experimentais e os que constam das fichas catalográficas desse banco de dados, com base na posição, intensidade relativa e forma dos picos observados. Outrossim, foi realizado um tratamento a fim de se obter o refinamento dos dados experimentais adquiridos pelo método de Rietveld, (que é um método matemático de refinamento de dados experimentais obtidos na análise dos dados do DRX). O método de Rietveld é um ajuste matemático interativo de um padrão real (dados experimentais) com um modelo (teórico), que utiliza o método dos mínimos quadrados para minimizar a diferença entre pontos medidos e calculados. Esse tratamento foi realizado utilizando-se de outro software da Bruker, o DIFRFRAC.TOPAS V.4.2. O software utiliza as informações constantes de arquivos CIF, que são obtidos por meio de perfis já catalogados que foram definidos na identificação de fases. Estes arquivos contemplam informações visuais das redes cristalinas dos compostos selecionados. Os procedimentos fornecem como resultados dados, como o diâmetro do cristalito além da 
quantidade relativa das fases, importantes para averiguar a eficácia do método de síntese usado.

\subsubsection{Microscopia eletrônica de varredura}

As imagens de MEV que foram obtidas neste trabalho se deu através de um Microscópio Eletrônico de Varredura JEOL JSM - 6510LV e um Microscópio Eletrônico de Varredura de bancada TM3000 da HITACHI, pertencente ao Centro de Microscopia da PUC-RIO. Foram selecionadas 7 amostras para a execução da microscopia eletrônica de varredura, a fim de possibilitar o estudo da morfologia e topografia da superfície destas. As amostras escolhidas foram: precursores (celulose, $\left.\mathrm{MgO}, \mathrm{Mg}(\mathrm{OH})_{2}\right)$, amostra II e $\mathrm{VI}$ e macerada com $10 \%$ de $\mathrm{MgO}$ ). As mesmas foram preparadas com um revestimento de carbono, obtido por meio de um pulverizador BALZERS SCD 050 e uma fita de carbono 16LZ02308VN Kohlegarnrn $L=3,5 \mathrm{~m}$, Leica para as amostras que foram revestidas com uma camada de carbono. Foram empregadas magnificação diversas a depender das especificidades dos materiais com EDS acoplado.

\subsubsection{Análise termogravimétrica}

A termogravimetria baseia-se no estudo da variação de massa de uma amostra, resultante de uma transformação física ou química em função do tempo ou da temperatura. A curva termogravimétrica, mostra o perfil de resistência ou estabilidade térmica que o material apresenta quando submetido a uma variação de temperatura. A partir da derivada da curva TGA (DTG), é possível a melhor visualização dos eventos térmicos e os intervalos de temperatura correspondentes (Mothé; Azevedo, 2009).

A análise termogravimétrica foi realizada em equipamento da marca NETZSCH, modelo STA 449 F3, como apresentado na figura 11, pertencente ao Laboratório de Análise Térmica do Departamento de Engenharia de Química e de Materiais da PUC-Rio. As curvas de TGA 
foram obtidas a uma taxa de aquecimento de $20 \mathrm{Kelvin/minuto,} \mathrm{utilizando-}$ se fluxo de oxigênio e nitrogênio.

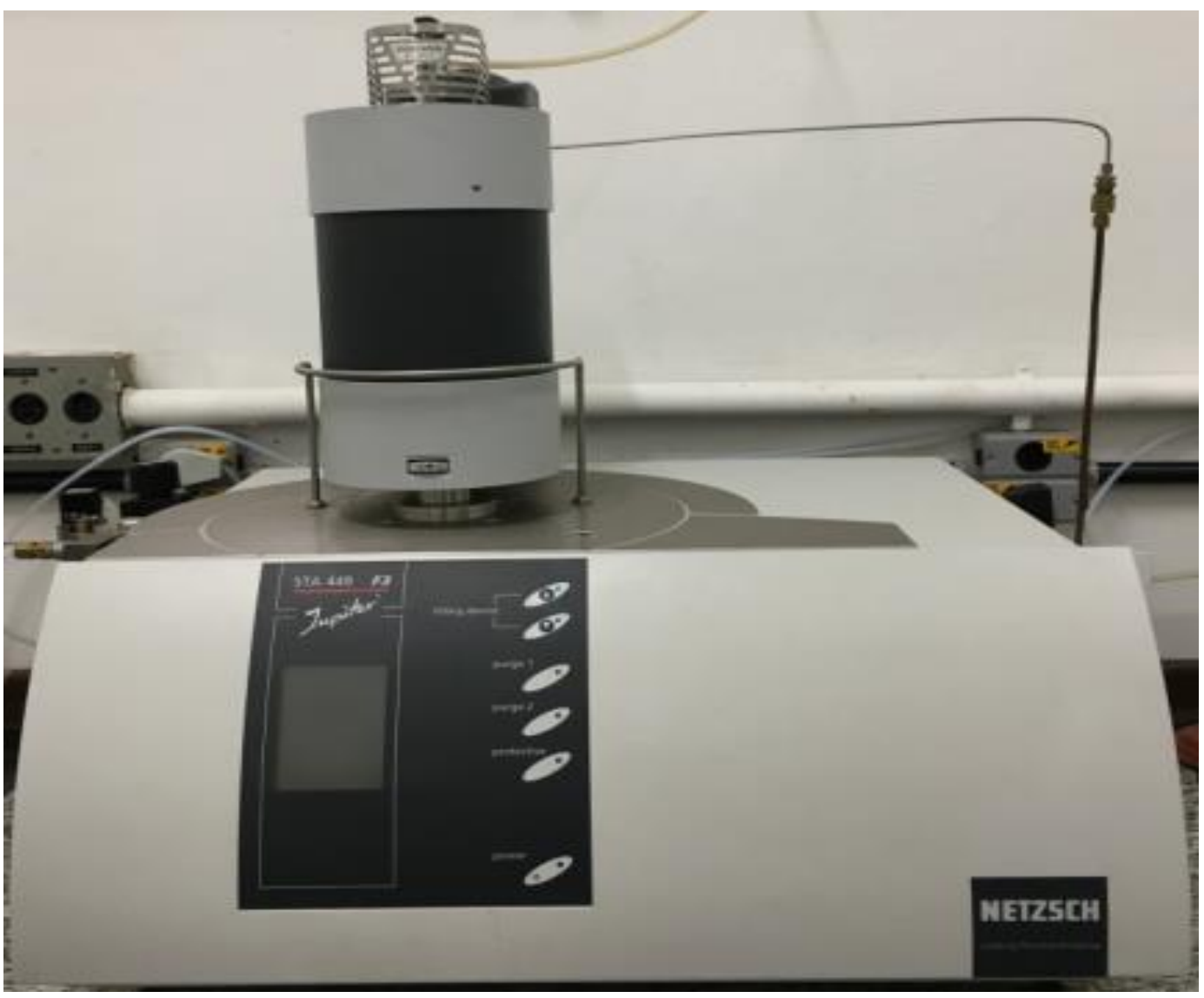

Figura 11: Aparelho analisador termogravimétrico utilizado.

\subsubsection{Cinética de decomposição usando análise termogravimétrica (TGA)}

Para determinar a energia de ativação da reação de decomposição usando o TGA foi usada a técnica desenvolvida por Speyer (1993). A decomposição se difere da nucleação e do crescimento, haja vista que a transformação do local não depende de os locais vizinhos terem se transformado. Assim, espera-se que a taxa dessa reação seja proporcional ao número de material deixados sem cobertura. O mesmo argumento seria válido para uma reação de primeira ordem:

$\frac{d x}{d t}=-k X$ 
$\mathrm{Na}$ expressão acima, $\mathrm{X}$ é a massa do reagente, e $\mathrm{k}$ é uma constante de taxa. Um expoente na massa do reagente é frequentemente usado na medida em que as reações de decomposição podem ser complexas, pois pode haver restrições à transformação, como a difusão de uma espécie gasosa do volume de um sólido ou fluxo de calor para a zona de reação. Portanto segue a expressão com o expoente usado:

$\frac{d x}{d t}=-k X^{n}$

O "n" é a "ordem" da reação. Essa expressão relaciona-se a informações que podem ser extraídas de um rastreamento do TGA usando:

$$
X=m_{0}-m_{0}\left(\frac{\mathrm{w}}{w_{\infty}}\right)
$$

Onde o mo é a massa inicial da amostra, w é a massa máxima perdida e w é a massa perdida, que varia com o tempo por meio da reação, como ilustrado na figura 11 . Antes do início da reação, $w=0$, então $X=m_{0}$. Depois que a reação estiver completa, tem-se, $w=w_{\infty}$, portanto, $X=0$. A derivada dessa expressão resulta:

$$
\frac{d X}{d t}=-\frac{m_{0} * d w}{w_{\infty} * d t}
$$




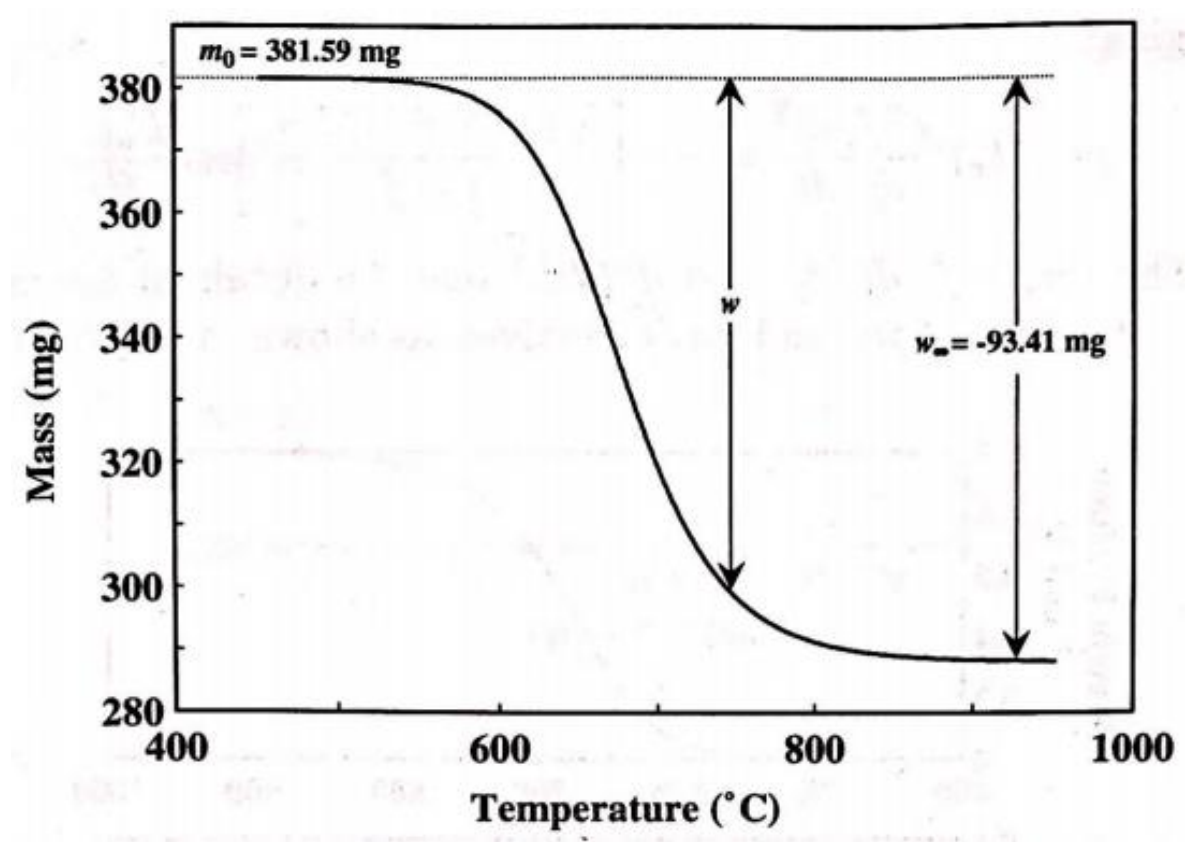

Figura 12: Variáveis definidas na análise da cinética de decomposição do TGA. Speyer (1993).

Substituindo a expressão anterior. Para $\mathrm{dx} / \mathrm{dt}$, bem como a expressão para X:

$$
\frac{-m_{0} * d w}{w_{\infty} * d t}=-k m_{0}{ }^{n} *\left(1-\left(\frac{w}{w_{\infty}}\right)\right)^{n}
$$

Ou:

$$
\frac{d *\left(\frac{w}{w_{\infty}}\right)}{d t}=K m_{0}{ }^{n-1}\left(1-\left(\frac{w}{w_{\infty}}\right)\right)^{n}
$$

O produto da fração de peso é definido como $f=w / w_{\infty}$, que encurta a expressão anterior para:

$$
\frac{d f}{d t}=k m_{0}{ }^{n-1}(1-f)^{n}
$$


Assumindo que a decomposição é um processo ativado, a constante de taxa é tomada para seguir a dependência da temperatura de Arrhenius:

$K=K_{0} * \exp \left(-\frac{E_{a}}{R T}\right)$

Com as devidas manipulações algébricas, adicionando a relação entre temperatura e tempo para uma taxa de aquecimento constante e rearranjo tem-se:

$(\emptyset t+T r)^{2} *\left(\frac{\left(d^{2} f / d t^{2}\right)}{\frac{d f}{d t}}\right)=-n *\left[\frac{(\emptyset t+T r)^{2} *\left(\frac{d f}{d t}\right)}{1-f}\right]+\frac{E_{a} \emptyset}{R}$

Os termos $f$, (df/dt) e $\left(d^{2} f / d t^{2}\right)$ podem ser obtidos diretamente da saída TGA e suas respectivas derivadas.

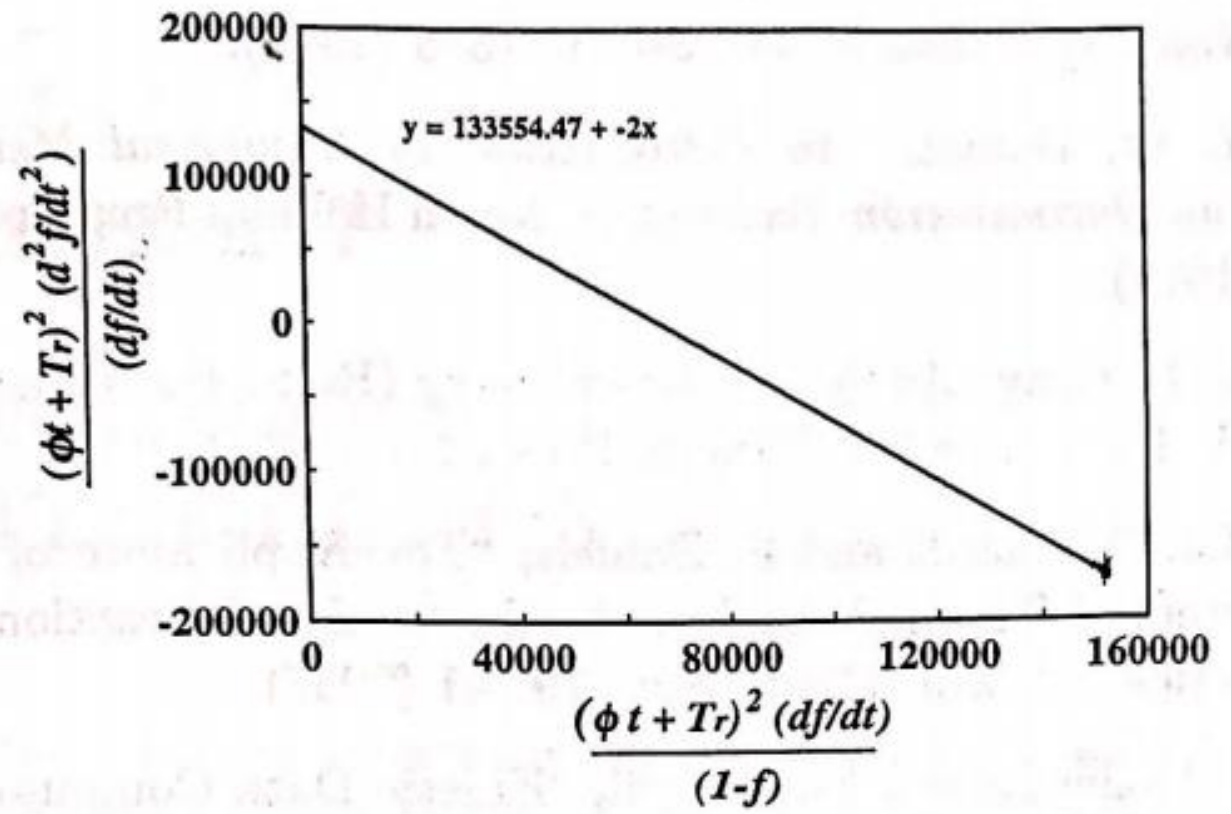

Figura 13: Gráfico usado para determinar a energia de ativação e a ordem de reação da decomposição térmica. A inclinação indica uma reação de segunda ordem e o intercepto, sendo $\mathrm{Ea} \emptyset / \mathrm{R}\left(\emptyset=10^{\circ} \mathrm{C} / \mathrm{min}\right)$, indica que a energia de ativação é $111 \mathrm{kj} / \mathrm{mol}$ (Speyer, 1993). 


\section{Resultados e discussões}

Os resultados e suas respectivas digressões serão apresentados observando-se os diferentes tratamentos aos quais as fibras de celulose foram submetidas, considerando as propriedades e parâmetros relevantes para a análise e avaliação comparativa entre estas. Dessa forma, após análises feitas para avaliar qualitativamente as matérias primas e os fibras tratadas, serão explorados os resultados concernentes à avaliação termodinâmica das reações, às caracterizações dos precursores e das amostras por meio do DRX e do MEV, às avaliações do comportamento térmico das amostras. Por fim uma análise cinética da fibra de celulose pura e da amostra VI que se mostrou mais sugestiva no que tange à aceleração do comportamento térmico.

\subsection{Análises precedentes}

Análises organolépticas preliminares foram realizadas antes dos exames mais complexos. Estas não apontaram distinções entre as fibras de celulose pura e as amostras tratadas pelas diferentes metodologias. As fibras tratadas no quesito integridade se mostraram parcialmente desagregadas e sem deformações, e no que tange à textura, apresentaram aspectos uniforme. No que diz respeito aos precursores (óxido de magnésio e hidróxido de magnésio em pó) observou-se aparência semelhante entre os materiais.

As análises preliminares supracitadas foram embasadas em critérios observáveis como tamanho das fibras e aspectos genéricos como mudança de cor e possíveis deformações. Outrossim, infere-se que a interação das fibras com os tratamentos anteriormente descritos na metodologia não alterou os aspectos gerais e observáveis das amostras. 


\subsubsection{Variação de massa referente aos testes de solubilidade descritos no item 3.2.1.3 da metodologia.}

Os testes de solubilidade do $\mathrm{MgO}$ e do $\mathrm{Mg}(\mathrm{OH})_{2}$ foram importantes para que se pudesse definir a quantidade de material que deveria entrar em cada etapa do processo de tratamento das fibras, tendo em vista a parcial solubilidade que os resultados demonstraram e quantidade de material que se pretendia ofertar para o sistema.

Tabela 2: Variação de massa para o teste de solubilidade.

\begin{tabular}{lccccc}
\hline & $\begin{array}{l}\text { Peso inicial } \\
(\mathrm{g})\end{array}$ & $\begin{array}{l}\text { Massa }(\mathrm{g}) \\
\text { residual à } \\
\text { temperatura } \\
\text { ambiente }\end{array}$ & $\begin{array}{l}\text { Perda } \\
\%\end{array}$ & $\begin{array}{l}\text { Massa (g) } \\
\text { residual a } \\
60^{\circ} \mathrm{C}\end{array}$ & $\begin{array}{l}\text { Perda } \\
\%\end{array}$ \\
\hline Teste I & 0,08 de MgO & 0,03 & 62,50 & 0,01 & 87,50 \\
\hline Teste II & $0,4 \mathrm{de} \mathrm{MgO}$ & 0,14 & 65,00 & 0,05 & 87,50 \\
\hline Teste III & $0,08 \mathrm{Mg}(\mathrm{OH})_{2}$ & 0,02 & 75,00 & 0,01 & 87,50 \\
\hline Teste IV & $0,4 \mathrm{Mg}(\mathrm{OH})_{2}$ & 0,11 & 72,50 & 0,03 & 92,50 \\
\hline
\end{tabular}

Com base nos dados apresentados na tabela 2, infere-se que não houve completa solubilidade em nenhuma das situações. Contudo todos os testes quando submetidos temperatura de $60^{\circ} \mathrm{C}$ evidenciaram melhores resultados no que diz respeito à solubilidade.

\subsection{Avaliação termodinâmica das reações}

O diagrama termodinâmico de especiação química visa representar o equilíbrio termodinâmico das fases líquidas e sólidas, este fornece as principais espécies químicas presentes em solução aquosa, de acordo com o pH do meio. Assim, a partir da distribuição química em função do $\mathrm{pH}$, fornecida pelo diagrama de cada composto, foi possível determinar a faixa de $\mathrm{pH}$ adequada para que se alcançasse uma boa dispersão das partículas de magnésio na solução de PVA. Esta faixa foi determinada com a intenção de evitar aglomerações e que ocorresse uma possível adsorção dos íons metálicos do magnésio nas fibras de celulose. 


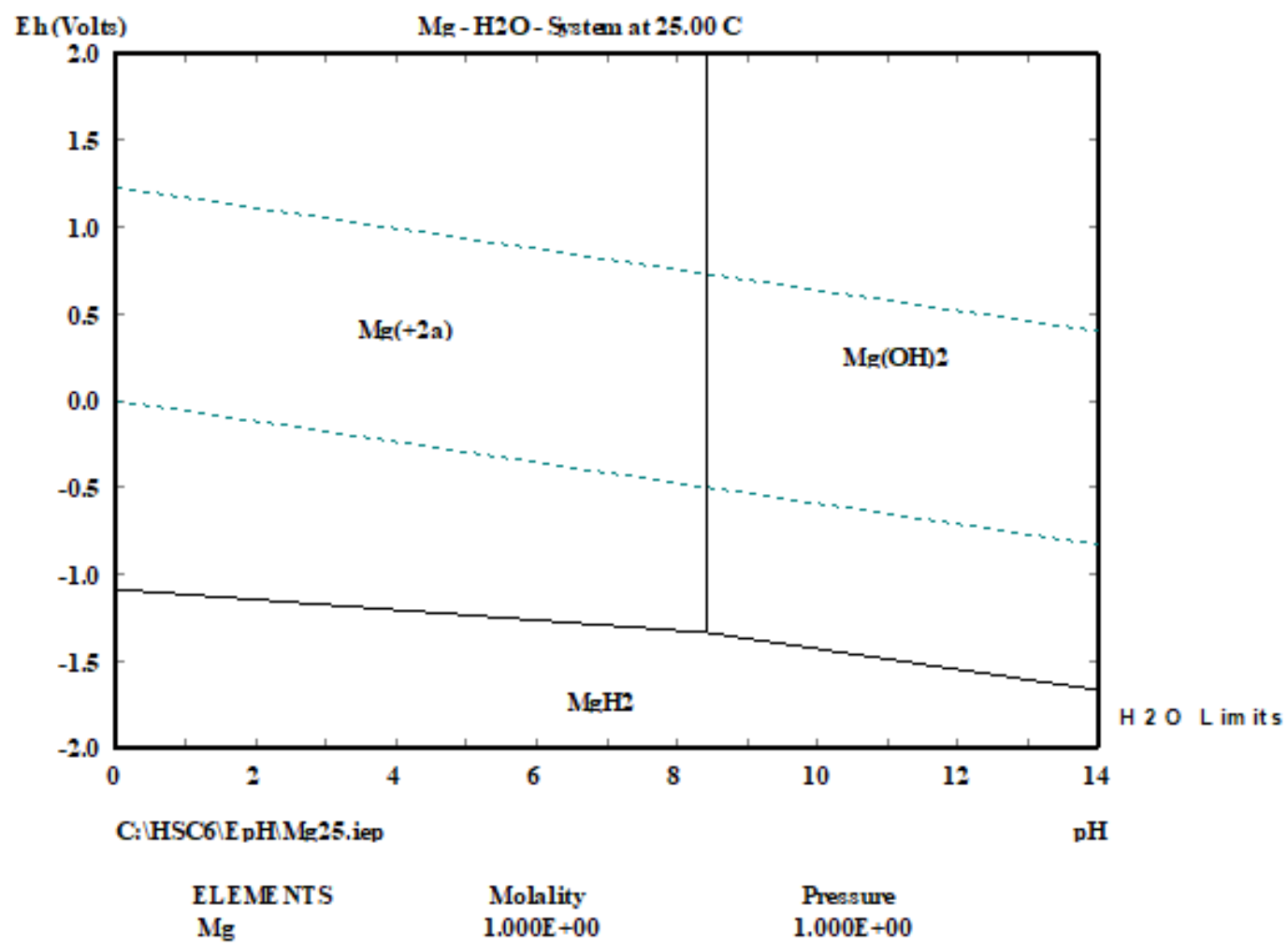

Figura 14: Diagrama de Pourbaix para o sistema $\mathrm{Mg}-\mathrm{O}-\mathrm{H}$ a $25^{\circ} \mathrm{C}$

De acordo com o diagrama (figura 14), a espécie $\mathrm{Mg}^{2+}$ apresentase na faixa de $\mathrm{pH}$ ácida até $\mathrm{pH}$ próximo de 8,5. Simultaneamente, nota-se a presença do composto $\mathrm{MgH}_{2}$ em toda a faixa de $\mathrm{pH}$, com ápice de concentração no meio neutro, sem chegar a ser o composto predominante. Enquanto que a formação da espécie $\mathrm{Mg}(\mathrm{OH})_{2}$ se inicia na faixa de $\mathrm{pH}$ alcalina e rapidamente atinge a máxima concentração, em seguida se estabiliza e passa a ser a espécie predominante do meio básico. A partir da simulação foi avaliada a decomposição térmica do hidróxido de magnésio, seguindo a reação 11 indicada abaixo.

$\mathrm{Mg}(\mathrm{OH})_{2} \rightarrow \mathrm{MgO}(\mathrm{s})+\mathrm{H}_{2} \mathrm{O}(\mathrm{g})$ 


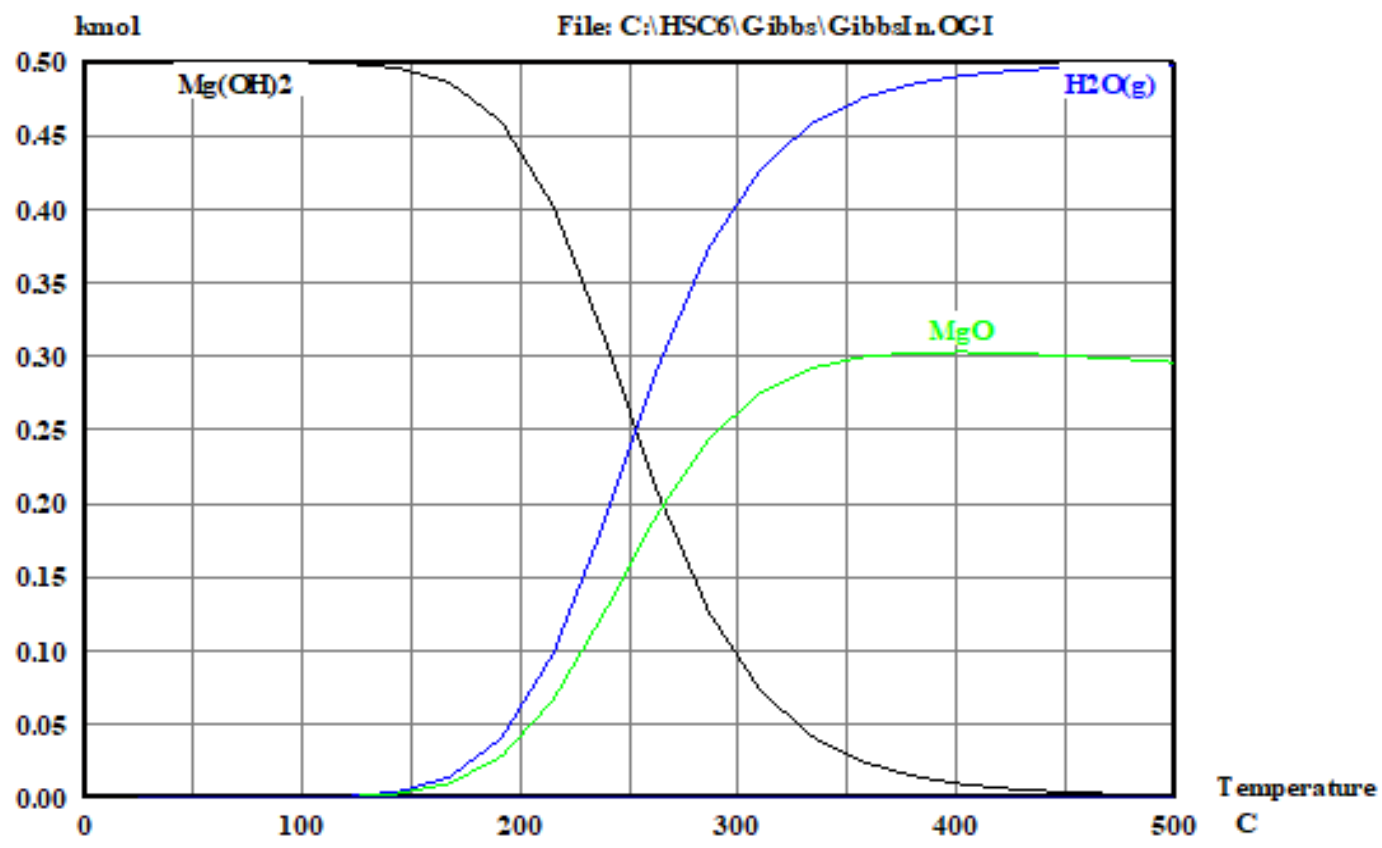

Figura 15: Diagrama de decomposição do hidróxido de magnésio

Na figura 15, observa-se que a decomposição do $\mathrm{Mg}(\mathrm{OH})_{2}$ ocorre a partir de, aproximadamente, 100 até $400^{\circ} \mathrm{C}$. Estes resultados são do ponto de vista termodinâmico, sem considerar efeitos cinéticos e sem a energia de ativação. Os valores médios de temperatura de decomposição informados em sua FISPQ é de $350^{\circ} \mathrm{C}$ para $\mathrm{o} \mathrm{Mg}(\mathrm{OH})_{2}$. Estes dados serão importantes na interpretação dos resultados obtidos nas análises termogravimétricas das amostras tratadas com este.

\subsection{Caracterização dos materiais precursores pela difração de raios- $\mathbf{X}$}

Antes de iniciar as avaliações e caracterizações das amostras submetidas aos tratamentos, será discutido o difratograma da fibra de celulose, do $\mathrm{Mg}(\mathrm{OH})_{2}$ e do $\mathrm{MgO}$ que foram as matérias-primas que estiveram envolvidas em todas as metodologias desenvolvidas no presente trabalho. Na figura 16 apresenta-se o difratograma da fibra de celulose usada nesta pesquisa. 


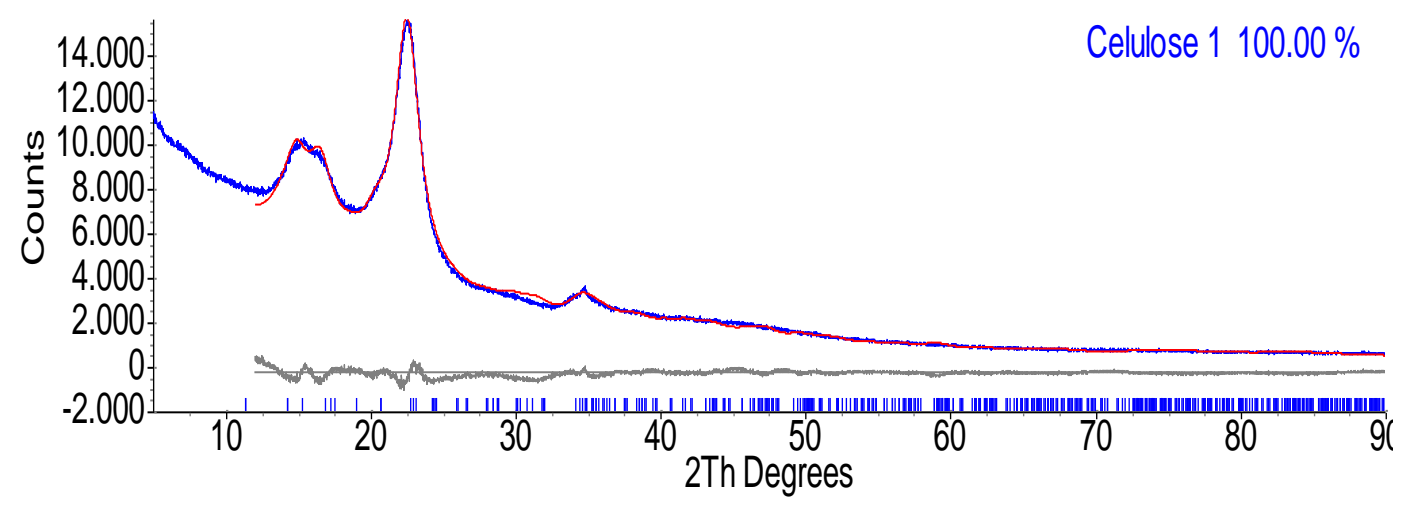

Figura 16: Difratograma da fibra de celulose

Neste difratograma da fibra de celulose (Figura 16) pode-se perceber picos com grande intensidade. Estes foram similares aos demonstrados por Bacellar (2014), que obteve suas fibras de celulose a partir da fibra do coco. Os picos se mostram bem definidos e são característicos da celulose.

No que diz respeito aos difratogramas de raios- $x$ obtidos para as amostras dos precursores $\mathrm{Mg}(\mathrm{OH})_{2}$ e $\mathrm{MgO}$ (Figura 17 (a) (b) (c) (d)), estes evidenciaram o padrão de difração característico para os respectivos materiais. Isso respalda a identificação do $\mathrm{Mg}(\mathrm{OH})_{2}$ e do $\mathrm{MgO}$ sintetizados no presente trabalho. Segundo a literatura quanto aos parâmetros de rede do hidróxido de magnésio, tem-se arestas com a = $3.1454130 \AA$ e c $=4.7610403 \AA$ (Catti et al., 1995), enquanto para o óxido de magnésio o valor de $a=4.0477421 \AA$ (Sasaki et al., 1979). Nos resultados obtidos pelo DIFRFRAC.TOPAS V.4.2 para a amostra caracterizada teve-se para 0 hidróxido de magnésio arestas com $\mathrm{a}=$ $3.1453501 \AA$ e $\mathrm{c}=4.7611870 \AA$; ; enquanto para o óxido de magnésio o valor de $a=4.2153644 \AA$. Os valores atingidos se diferiram da literatura, sugerindo assim alguma contaminação ou impureza na amostra. Esses parâmetros serão utilizados para discutir os resultados das amostras tratadas com estes materiais. 

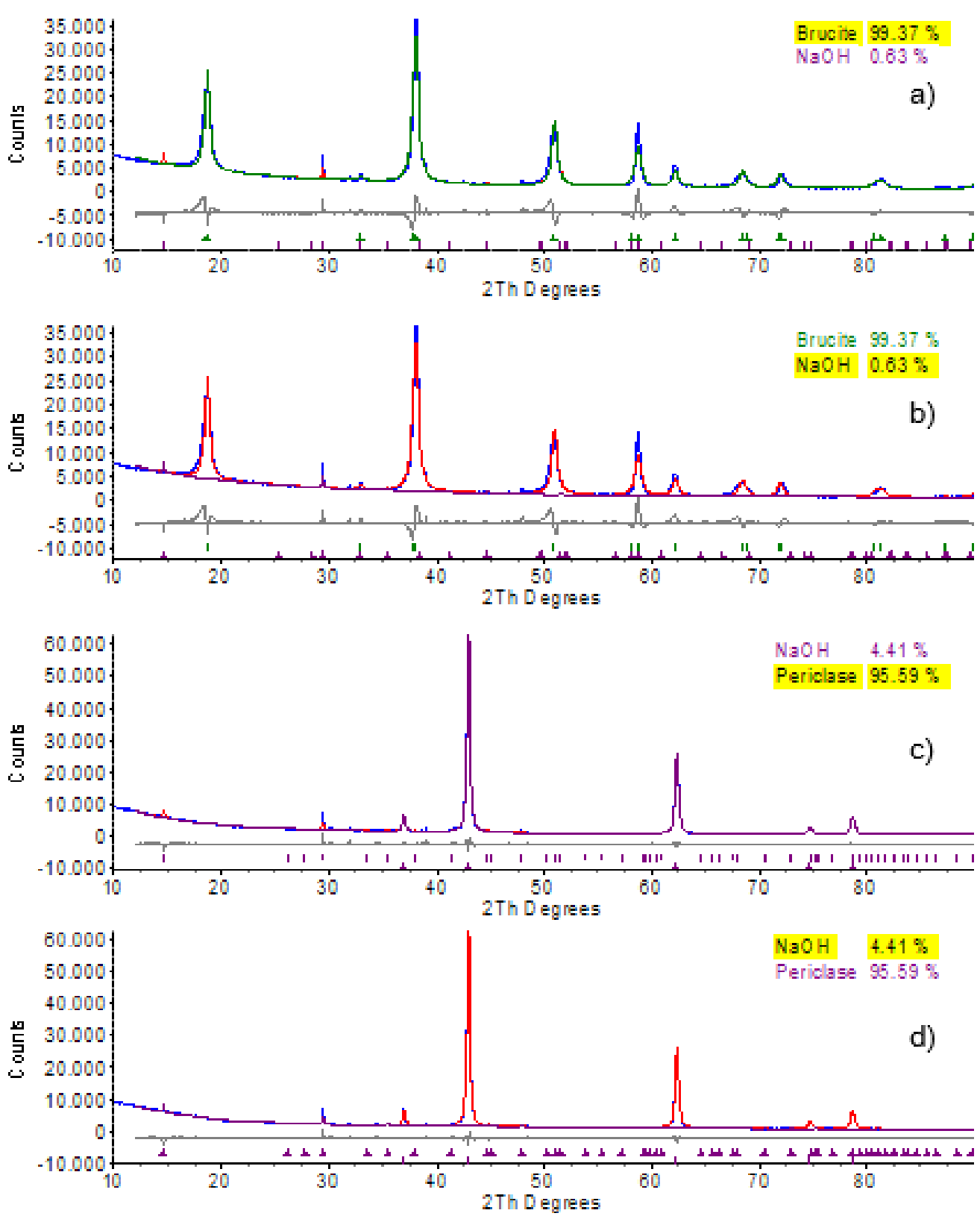

Figura 17: Difratograma de raios- $\mathrm{X}$ do $\mathrm{Mg}(\mathrm{OH})_{2}$ em (a) e (b) e do $\mathrm{MgO}$ em (c) e (d).

Os resultados apresentaram um tamanho médio de cristalito de $18.1 \mathrm{~nm}$ e de $39,6 \mathrm{~nm}$ para $\circ \mathrm{Mg}(\mathrm{OH})_{2}$ e $\circ \mathrm{MgO}$, respectivamente. A brucita e o periclásio se apresentam majoritariamente no difratograma inerente a cada um (gráfico (a) e (c)) e a presença do $\mathrm{NaOH}$ em ambos resultados se justifica pela metodologia usada para obtenção do material que foi descrita no item 3.2.1.1 que fez uso do hidróxido de sódio na síntese do material. No estudo de Ding et al., (2001), foi realizada a 
caracterização via $\mathrm{DRX}$ do $\mathrm{Mg}(\mathrm{OH})_{2}$ e do $\mathrm{MgO}$. Eles reportam que os padrões de DRX das amostras são compatíveis com a base de dados do International Center for Difraction Data (ICDD), o que atesta a identificação do $\mathrm{Mg}(\mathrm{OH})_{2}$ e do $\mathrm{MgO}$ sintetizados por eles. Ressaltam ainda que o alargamento dos picos de difração infere que as partículas de $\mathrm{Mg}(\mathrm{OH})_{2}$ e de $\mathrm{MgO}$ são, demasiadamente, pequenas o que vai ao encontro dos resultados obtidos nesta pesquisa.

\subsubsection{Caracterizações da superfície dos materiais precursores}

A partir das imagens obtidas por microscopia eletrônica de varredura (MEV) e seu gráfico de composição, foi possível analisar a morfologia superficial dos precursores e a composição química da amostra. Na figura 18 observa-se a imagem da celulose pura, com magnificação de $250 \mathrm{X}$.

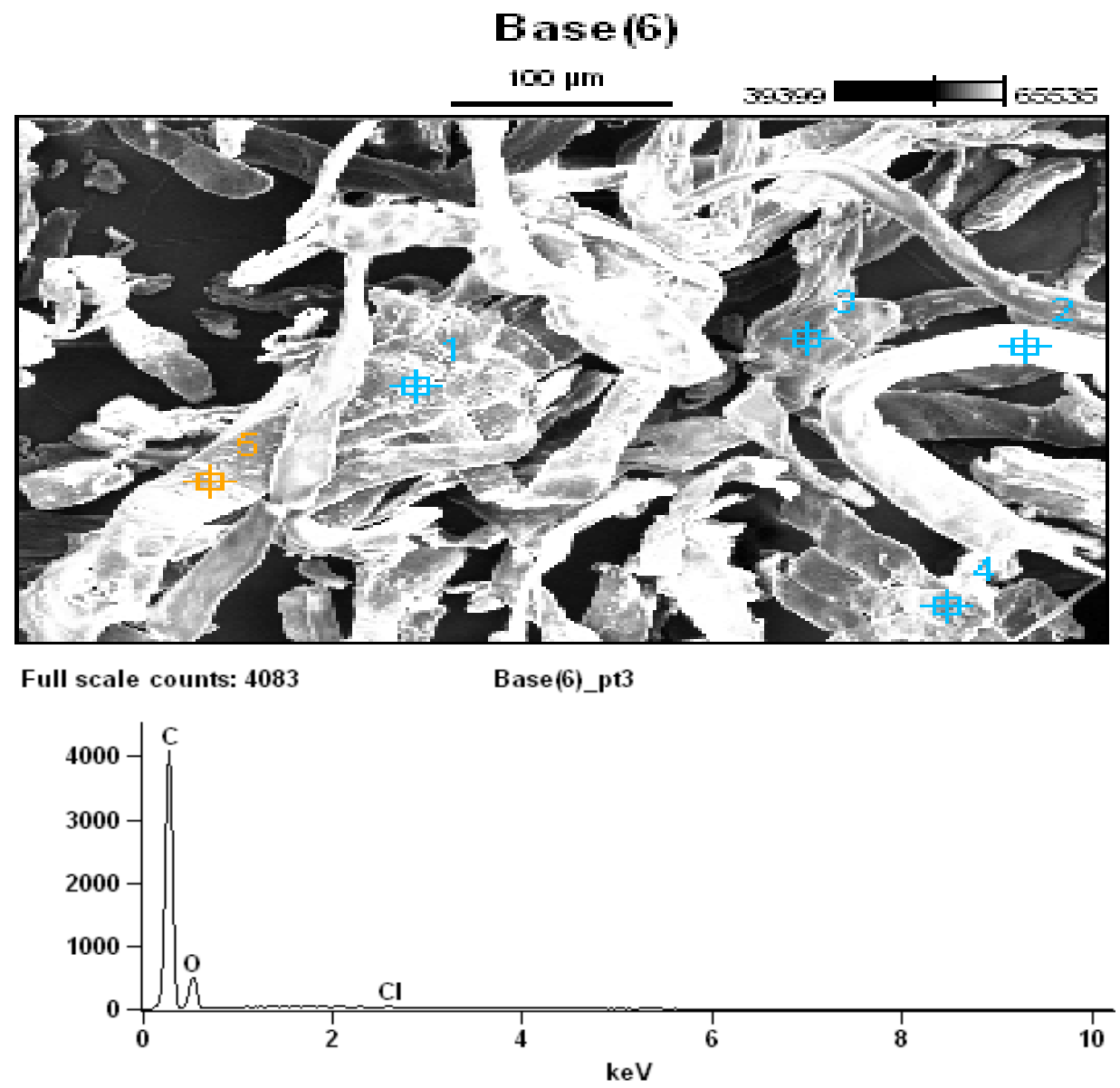

Figura 18: Micrografias de MEV com gráfico de composição das fibras de celulose com magnificação de $250 \mathrm{X}$. 
Tabela 3: Resumo dos constituintes da amostra de celulose caracterizada pelo MEV

\begin{tabular}{lccc}
\hline & \multicolumn{3}{c}{ Peso em \% } \\
\hline & Carbono & Oxigênio & Cloro \\
\hline Base(6)_pt1 & 71.50 & 28.50 & \\
\hline Base(6)_pt2 & 73.76 & 26.24 & \\
\hline Base(6)_pt3 & 71.58 & 28.29 & \\
\hline Base(6)_pt4 & 71.92 & 28.08 & \\
\hline Base(6)_pt5 & 73.02 & 26.98 & \\
\hline
\end{tabular}

Com base nos dados obtidos na tabela 3 , infere-se que a composição química da fibra de celulose estudada é similar a apresentada na literatura, contendo carbono majoritariamente e oxigênio. No espectro 3 , notou-se a presença de cloro. Neste trabalho, a fibra da celulose usada foi comercial, o que pode justificar a presença do elemento haja vista o processo de obtenção da mesma. Na figura 19, temse uma imagem dos outros dois materiais precursores utilizados nesta pesquisa, o $\mathrm{Mg}(\mathrm{OH})_{2}$ e o $\mathrm{MgO}$ e seus respectivo mapa de EDS. Pode se perceber a presença do sódio e do magnésio majoritariamente em ambas amostras, embora se tenha feito lavagens com água deionizada na fase de filtragem após a síntese do material, o sódio se manteve presente. 


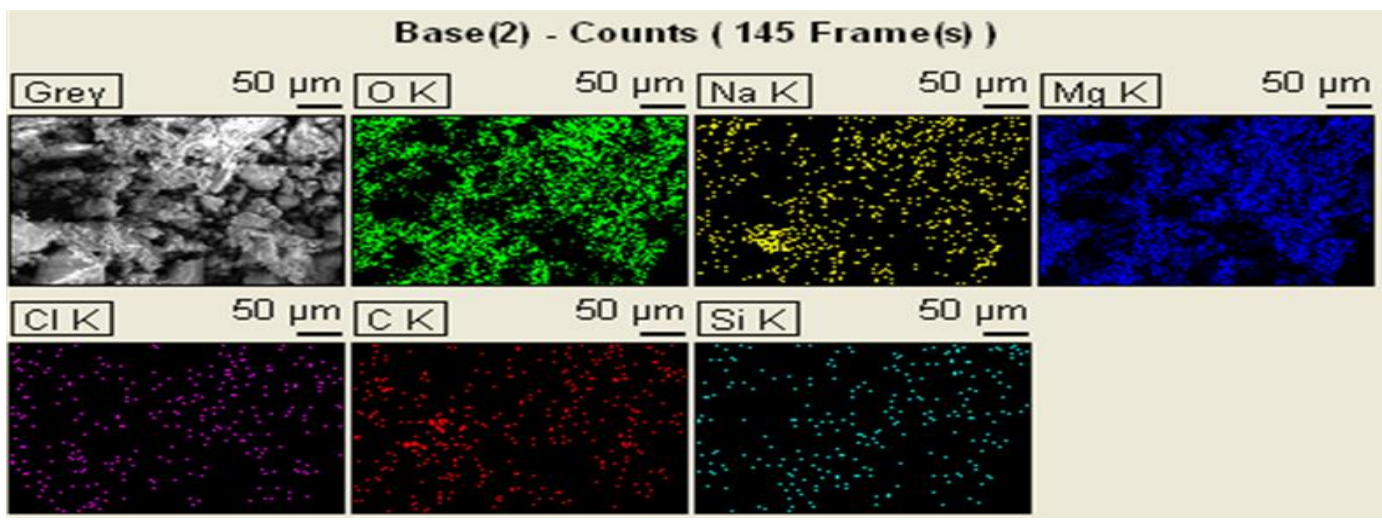

Full scale counts: 8545

Base (2)
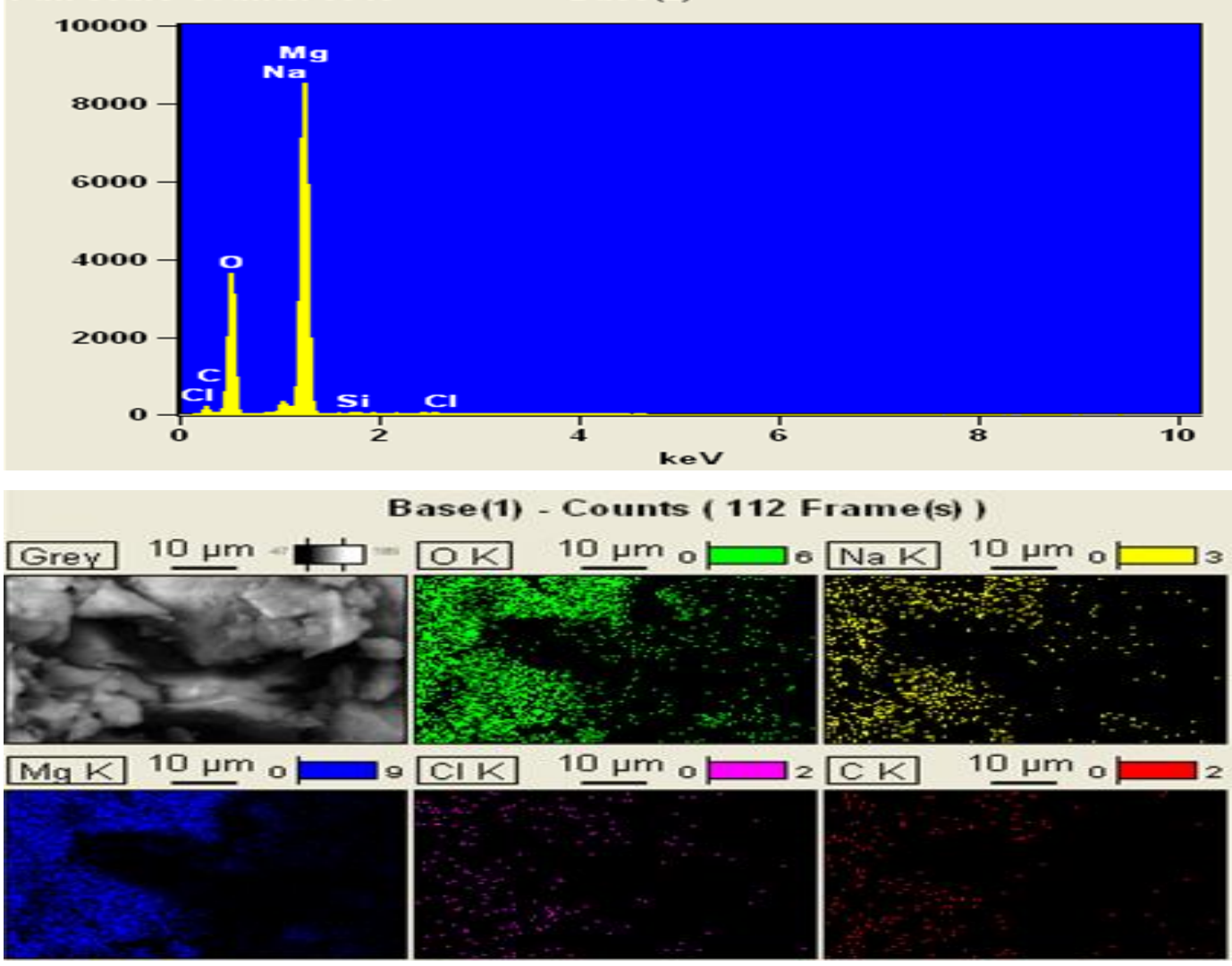

Full scale counts: 4498

Base (1)

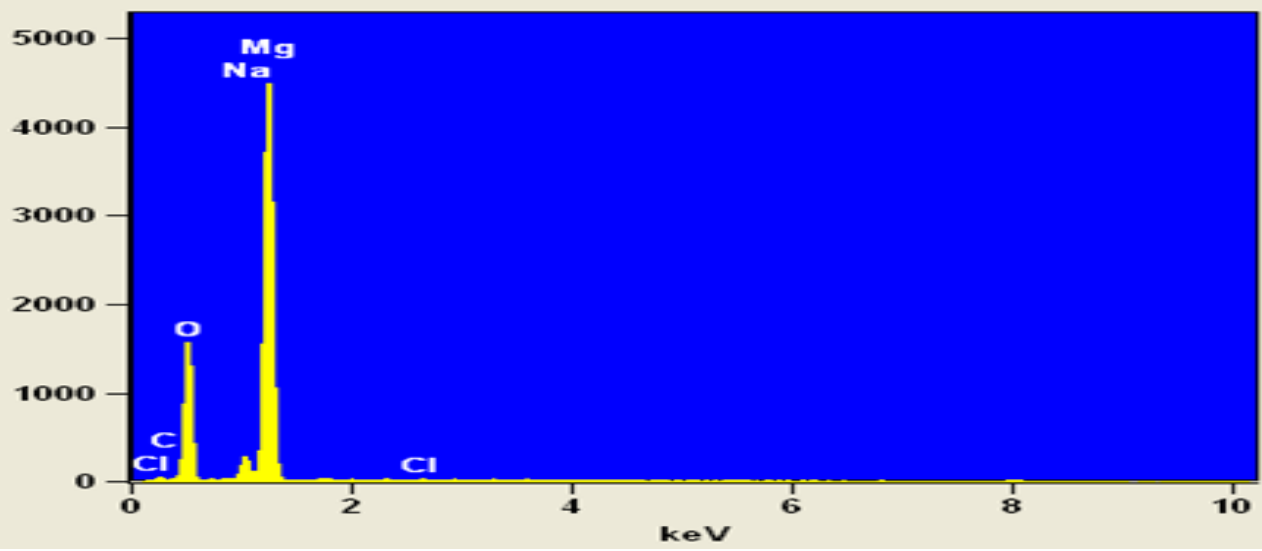

Figura 19: Imagens de MEV com mapas de EDS do $\mathrm{Mg}(\mathrm{OH})_{2} \mathrm{com}$ magnificação de $340 \mathrm{X}$ e do $\mathrm{MgO}$ com magnificação de $2000 \mathrm{X}$. 
As imagens evidenciam a morfologia típicas desses materiais, assim como foi observado na figura 4, que são micrografias obtidas em 2004, por Yu e colaboradores, mostrando as características morfológicas das superfícies do $\mathrm{Mg}(\mathrm{OH})_{2}$ e $\mathrm{MgO}$, apresentadas nas 4 a) e c). A micrografia do $\mathrm{Mg}(\mathrm{OH})_{2}$ da figura 19 mostra um aglomerado de microestruturas globulares, diferentes da estrutura conhecida de plaquetas hexagonais apontadas por Yu et al., (2004) relativas à sua estrutura cristalina. As estruturas globulares podem ser descritas como grandes agregados de unidades esféricas com diâmetros da ordem de $300 \mathrm{~nm}$ (Henrist et al., 2003). A microestrutura constatada nas micrografias pode ser explicada pela escolha do agente precipitante, $\mathrm{NaOH}$. $\mathrm{O} \mathrm{pH}$ do meio reacional e a natureza dos íons presentes na síntese exercem influência sobre o crescimento dos cristais. Então, o pH elevado aumenta o nível de supersaturação da solução devido à grande quantidade de íons hidroxila e acelera o processo de nucleação, gerando inúmeros núcleos pequenos e malformados (Henrist et al., 2003). Nas análises com EDS, foram encontradas quantidades significativas de sódio na composição do $\mathrm{Mg}(\mathrm{OH})_{2}$ obtido. Henrist e colaboradores (2003), relataram em seus estudos que em pH's elevados, é esperado que a carga residual na superfície das partículas seja negativa. Somado a isto, existe uma grande concentração de pequenos íons $\mathrm{Na}^{+}$dispersos no meio aquoso. Logo os íons $\mathrm{Na}^{+}$presentes na solução podem ser facilmente adsorvidos na superfície das partículas dos hidróxidos sem qualquer seletividade, obstando o arranjo de novos núcleos e afetando o crescimento dos núcleos existentes (Carvalho, 2016).

\subsection{Caracterização das amostras}

\subsubsection{Caracterização dos materiais posterior à análise termogravimétrica em atmosfera oxidante}

As variações de massa ao final das análises termogravimétrica, foram elencadas na tabela 4 . 
Tabela 4: Variação de massa das amostras estudadas, em atmosfera oxidante.

\begin{tabular}{|c|c|c|c|}
\hline \multicolumn{4}{|c|}{ Em fluxo de $\mathrm{O}_{2}$} \\
\hline Material & $\begin{array}{l}\text { Massa de entrada } \\
(\mathrm{mg})\end{array}$ & $\begin{array}{l}\text { Massa de saída } \\
\text { (mg) }\end{array}$ & $\begin{array}{l}\text { Perda } \\
\%\end{array}$ \\
\hline Celulose pura & 40,70 & 0,09 & 99,78 \\
\hline $\begin{array}{l}\text { Amostra tratada com 2\% } \\
\text { de } \mathrm{Mg}(\mathrm{OH})_{2} \text { (pó) na }\end{array}$ & & & \\
\hline solução de PVA & 42,80 & 0,44 & 98,96 \\
\hline $\begin{array}{l}\text { Amostra tratada com 10\% } \\
\text { de } \mathrm{Mg}(\mathrm{OH})_{2} \text { (pó) na }\end{array}$ & & & \\
\hline solução de PVA & 41,80 & 0,28 & 99,34 \\
\hline $\begin{array}{l}\text { Amostra tratada com } 2 \% \\
\text { de } \mathrm{Mg}(\mathrm{OH})_{2} \text { em solução }\end{array}$ & 40,90 & 0,22 & 99,46 \\
\hline $\begin{array}{l}\text { Amostra tratada com } 10 \% \\
\text { de } \mathrm{Mg}(\mathrm{OH})_{2} \text { em solução }\end{array}$ & 40,90 & 0,16 & 99,60 \\
\hline $\begin{array}{l}\text { Amostra tratada com } 2 \% \\
\text { de } \mathrm{Mg}(\mathrm{OH})_{2} \text { dissolvido a }\end{array}$ & & & \\
\hline $60^{\circ} \mathrm{C}$ & 45,20 & 0,26 & 99,43 \\
\hline $\begin{array}{l}\text { Amostra tratada com } 10 \% \\
\text { de } \mathrm{Mg}(\mathrm{OH})_{2} \text { dissolvido a }\end{array}$ & & & \\
\hline $60^{\circ} \mathrm{C}$ & 41,50 & 0,16 & 99,62 \\
\hline Celulose $+5 \%$ de $\mathrm{MgO}$ & & & \\
\hline macerado & 40,00 & 1,90 & 95,26 \\
\hline Celulose $+10 \%$ de $\mathrm{MgO}$ & & & \\
\hline macerado & 40,50 & 2,71 & 93,30 \\
\hline
\end{tabular}

$\mathrm{Na}$ tabela 4, uma breve apresentação no que tange à variação de massa mensurada ao final das análises termogravimétricas em temperaturas até $600^{\circ} \mathrm{C}$. As amostras que apresentaram menores perdas em porcentagens foi a amostra macerada com $5 \%$ de $\mathrm{MgO}$ e a amostra macerada com $10 \%$ de $\mathrm{MgO}$. Por meio dessas observações, é possível estabelecer uma relação dos resultados aqui obtidos para cada evento estudado nesse item com os resultados observados no DRX das 
respectivas amostras. Essas considerações serão apontadas no item abaixo.

\subsubsection{Difratogramas obtido para: amostra I, amostra II, amostra III (sol.) e amostra IV (sol.).}

Assim como nas pesquisas de Wang (2008), foi constatado que tratamentos químicos consecutivos nas fibras da celulose acarretam diferentes padrões de difração de raios-X, como pode ser observado nos difratogramas da figura 20.
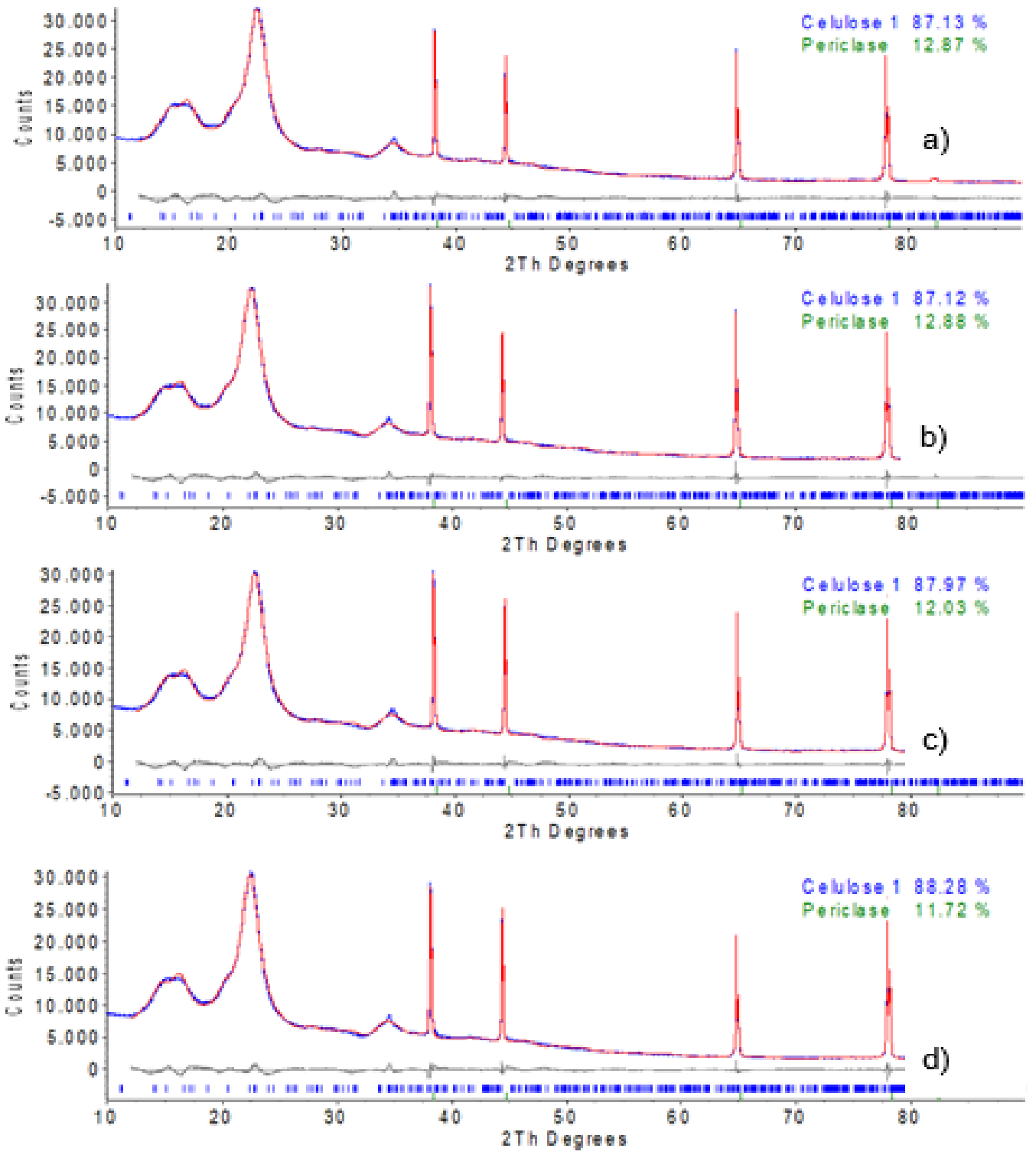

Figura 20: Difratograma de raios-X das amostras I, II, III (solução) e IV (solução) em a), b), c), d) respectivamente. 
$\mathrm{Na}$ tabela 5, foi feito um quadro resumo com os dados apresentados pelos difratogramas de raios-x para cada material.

Tabela 5: Parâmetros cristalográficos obtidos nas análises de DRX

\begin{tabular}{|c|c|c|c|}
\hline & $\begin{array}{l}\text { Parâmetros de } \\
\text { rede - aresta }(\AA)\end{array}$ & $\begin{array}{l}\text { Tamanho médio } \\
\text { dos cristalitos (nm) }\end{array}$ & Composição \% \\
\hline \multirow{2}{*}{ Amostra I } & \multirow{2}{*}{$a=4.0477831$} & \multirow{2}{*}{170.50} & Celulose: 87,13 \\
\hline & & & Periclásio: 12,87 \\
\hline \multirow{2}{*}{ Amostra II } & \multirow{2}{*}{$a=4.0474108$} & \multirow{2}{*}{175.20} & Celulose: 87,12 \\
\hline & & & Periclásio: 12,88 \\
\hline \multirow{2}{*}{ Amostra III } & \multirow{2}{*}{$a=4.0474484$} & \multirow{2}{*}{182.40} & Celulose: 87,97 \\
\hline & & & Periclásio: 12,03 \\
\hline \multirow{2}{*}{ Amostra IV } & \multirow{2}{*}{$a=4.0475185$} & \multirow{2}{*}{181,80} & Celulose: 88,28 \\
\hline & & & Periclásio: 11,72 \\
\hline Celulose & - & 4,50 & Celulose: 100 \\
\hline \multirow{2}{*}{$\mathrm{Mg}(\mathrm{OH})_{2}$} & $a=3.1454130$ & \multirow{2}{*}{18.10} & Brucita: 99,37 \\
\hline & $C=4.7611870$ & & $\mathrm{NaOH}: 0,63$ \\
\hline \multirow{2}{*}{$\mathrm{MgO}$} & \multirow{2}{*}{$a=4.2153644$} & \multirow{2}{*}{39.40} & Periclásio: 95,59 \\
\hline & & & $\mathrm{NaOH}: 4,41$ \\
\hline
\end{tabular}

Com base nas composições apresentadas na tabela 5, as amostras possuem uma composição diferente do que se esperava, na medida em que as porcentagens de periclásio se mostram acima do que realmente foi oferecido ao sistema. Contudo, na tabela 5, os dados referentes às perdas de massa das amostras após as análises termogravimétricas em atmosfera oxidante, são condizentes com 0 comportamento esperado para a composição das mesmas. Considerando que: a maior parte do constituinte da amostra é celulose; que os dados da tabela 2 apontaram que $\mathrm{o} \mathrm{Mg}(\mathrm{OH})_{2}$ não tem completa solubilidade na solução de PVA; e que a celulose deveria se decompor totalmente em atmosfera oxidante a exceção de alguma eventual contaminação.

Uma possível causa para o resultado encontrado no DRX, pode estar na aglomeração das partículas de $\mathrm{Mg}(\mathrm{OH})_{2}$. Fator relevante já levantado por diversos estudos é a dispersão não efetiva de 
nanopartículas. Também se configura numa possível causa, a não representatividade da amostra quando se separou uma pequena parte para realizar esta caracterização.

Outro fator relevante, é que as amostras I e II foram tratadas com $\mathrm{Mg}(\mathrm{OH})_{2}$ em pó, e as amostras III e IV foram tratadas com $\mathrm{Mg}(\mathrm{OH})_{2}$ em solução, então o esperado é que na composição apontada no DRX fosse uma porcentagem de brucita e não periclásio como exposto acima. Não foi encontrado dados na literatura que ajudassem a compreender melhor esse quesito.

\subsubsection{Caracterizações da superfície das amostras tratadas}

A partir das imagens obtidas por microscopia eletrônica de varredura, foi possível analisar não apenas a morfologia superficial das fibras de celulose tratadas, como também a forma de dispersão das partículas dos hidróxidos e óxidos de magnésio usados no estudo. As micrografias obtidas foram importantes para que se apontasse, qualitativamente, a forma de dispersão dos metais alcalinos terrosos usados no tratamento das amostras investigadas. 


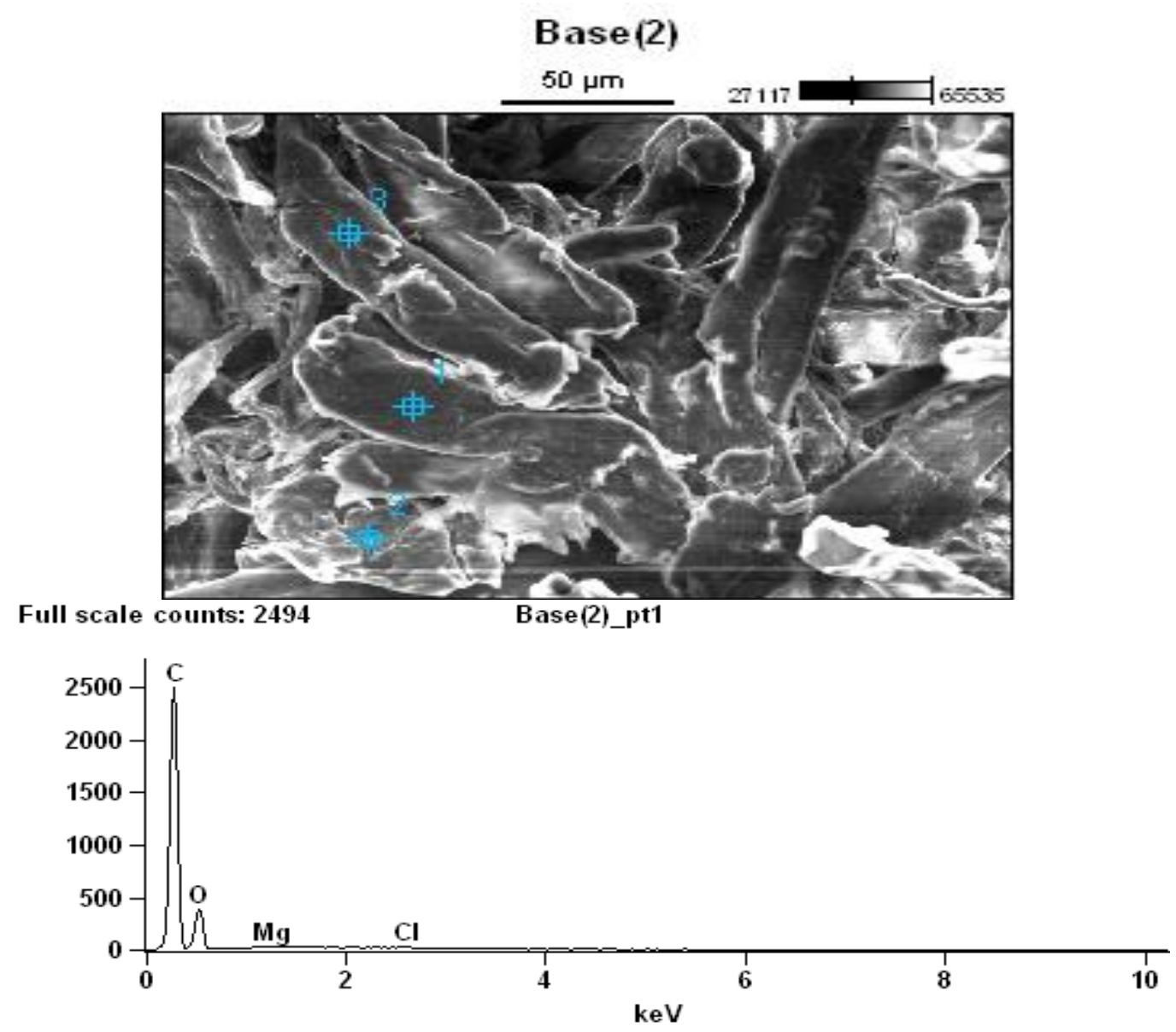

Figura 21: Imagens de MEV da Amostra II, com magnificação de $500 \mathrm{X}$

$\mathrm{Na}$ figura 21, pela micrografia da amostra II, visualiza-se a fibra de celulose, está se mostra semelhante à micrografia demonstrada na figura 18 que é da celulose antes de sofrer qualquer tratamento. Não é possível identificar $\mathrm{Mg}(\mathrm{OH})_{2}$ em estado sólido, embora se saiba que não houve completa solubilidade deste na solução de tratamento. Contudo no gráfico na parte inferior da figura 21, pode-se identificar o magnésio, o que sugere que houve uma dispersão satisfatória na superfície das fibras. Nesse sentido na figura 22, que mostra a micrografia da amostra VI, com magnificação de $12000 \mathrm{X}$, as fibras se encontram, ainda, com aspectos morfológicos característicos da celulose e não foi possível identificar cargas de hidróxidos de magnésio separadas das fibras de celulose. Alguns aglomerados de encolagem foram observados em pontos da amostra e nas demais áreas, a celulose se apresenta dispersa em toda a 
extensão da amostra. Em seu mapa de EDS é possível perceber a significativa dispersão do magnésio pela fibra analisada.
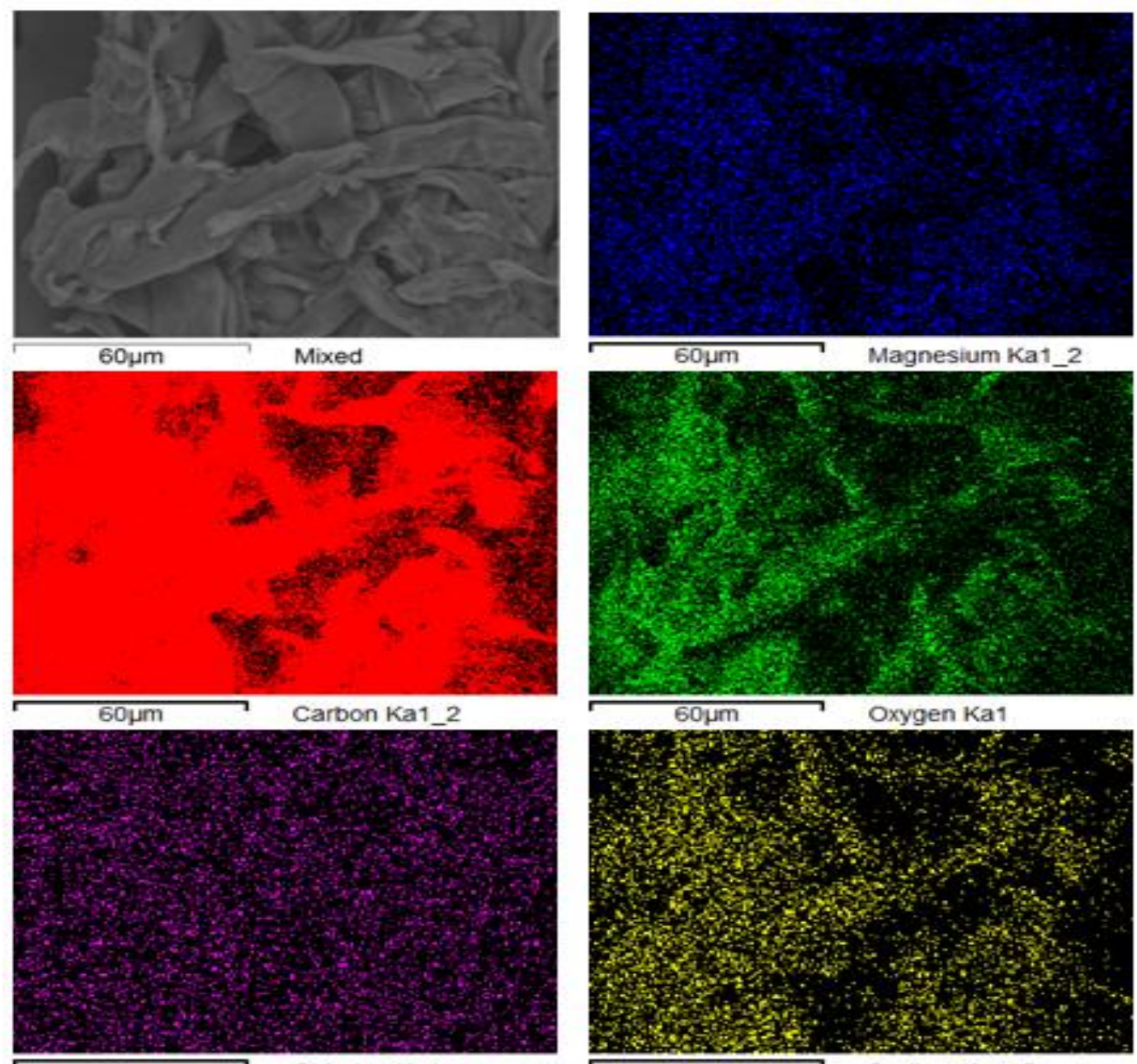

60jm

Chlorine Ka1

$60 \mu \mathrm{m}$

Sodium Ka1_2

Figura 22: Imagens de MEV da Amostra VI, magnificação de $12000 \mathrm{X}$

Tabela 6: Resumo dos resultados

\begin{tabular}{ll}
\hline Elemento & Peso \% \\
\hline Carbono & 87.985 \\
\hline Oxigênio & 11.272 \\
\hline Magnésio & 0.109 \\
\hline Alumínio & 0.634 \\
\hline
\end{tabular}

Na figura 22, com baixas magnificação, verificou-se que há regiões vazias na amostra, nas quais as lacunas existentes entre as fibras não 
foram totalmente preenchidas e/ou aderidas pelas nanocargas que foram maceradas em conjunto com as fibras. Partículas sólidas do $\mathrm{MgO}$ podem ser vislumbradas em alguns pontos específicos da amostra como mostra a micrografia respectiva.

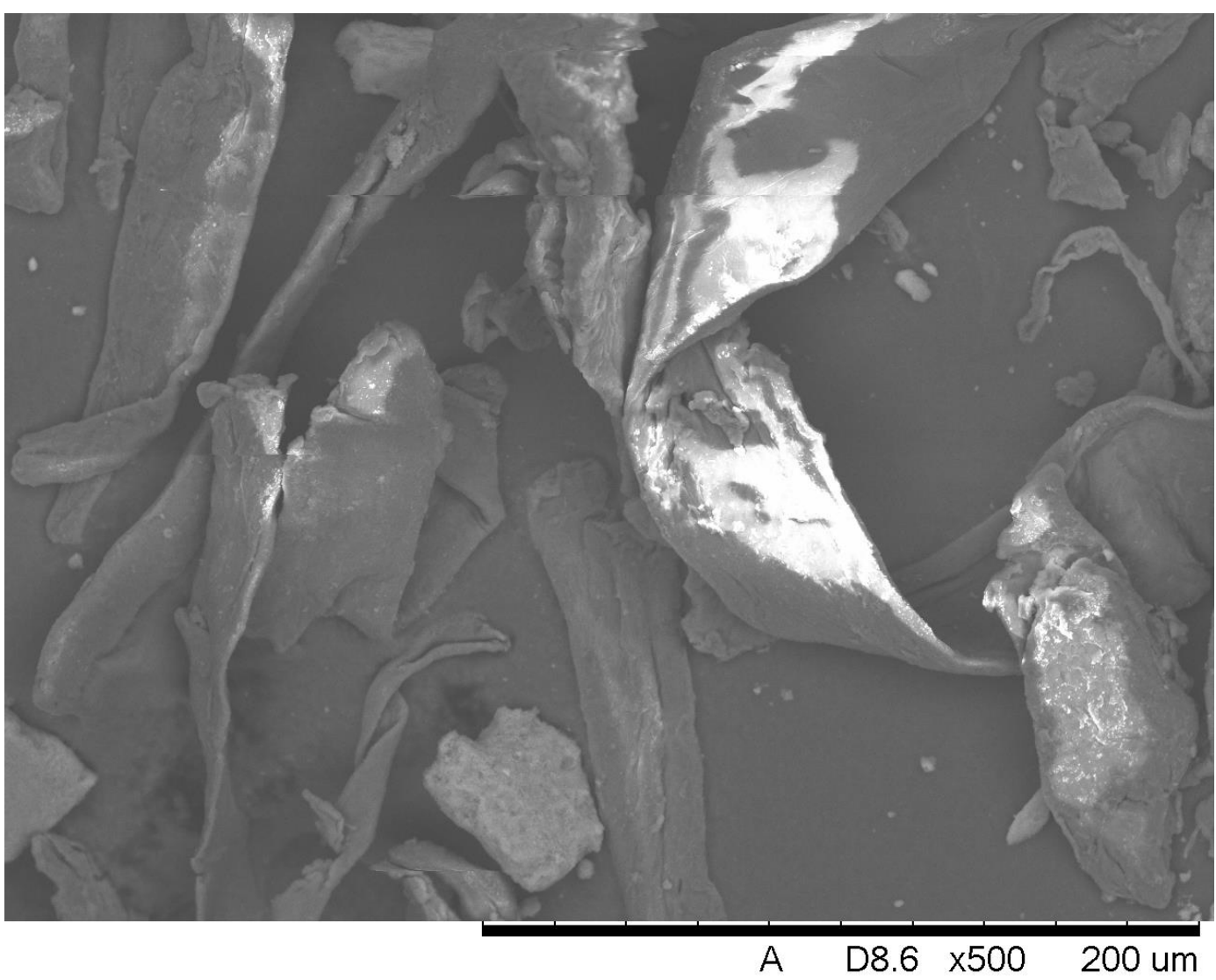

Figura 23: Imagens de MEV da amostra de celulose macerada com $10 \%$ de $\mathrm{MgO}$, magnificação de $500 \mathrm{X}$

Essa imagem sugere que a interação fibra/MgO não é tão eficiente quando se trata de material sólido-sólido. Isto foi benéfico para a análise das demais amostras, sugerindo, assim, maior afinidade dos materiais quando submetidas aos tratamentos via solução, uma vez que conduziu notavelmente a uma melhor distribuição. Nota-se um efeito de carregamento na imagem.

Com intuito de conhecer a morfologia da massa remanescente dos ensaios de TGA, foram feitas também micrografias do material residual, na figura 24, pode-se verificar a morfologia e composição dessa amostra em seu respectivo mapa de EDS. 


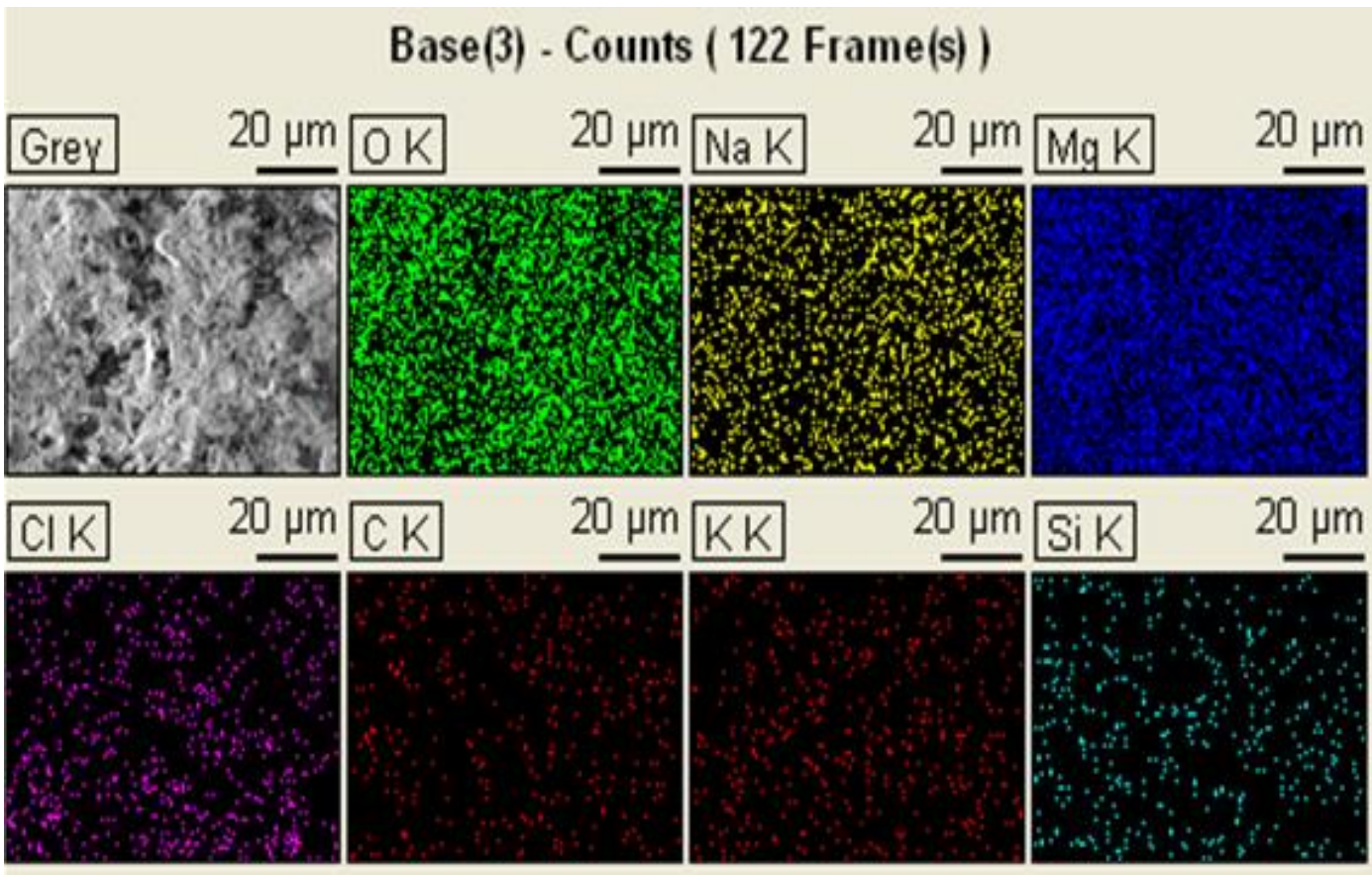

Full scale counts: 7164

Base (3)

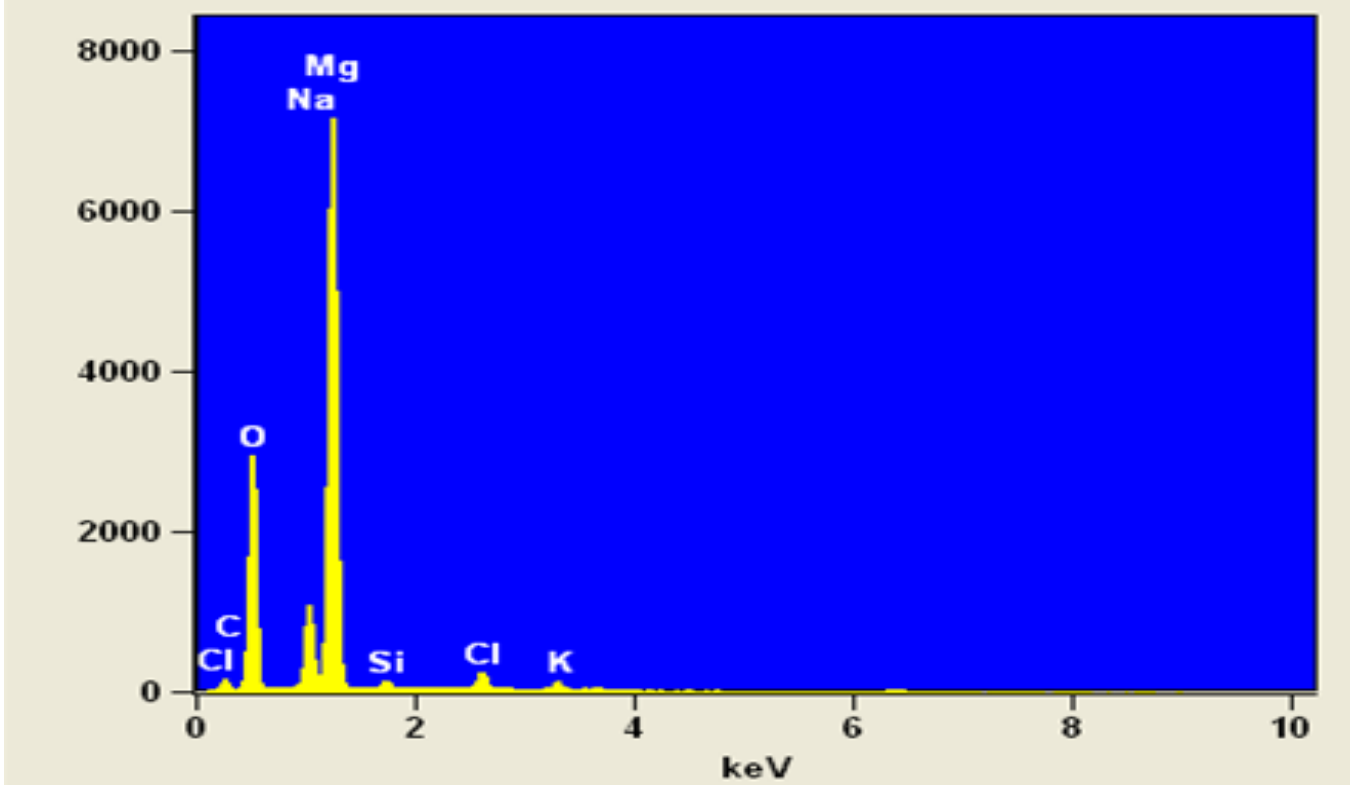

Figura 24: Imagem de MEV com mapas de EDS do resíduo proveniente do TGA feito da amostra VI em atmosfera oxidante, com magnificação de $1480 \mathrm{X}$.

A micrografia observada na figura 24 , foi de suma importância para que se verificasse a presença de magnésio na composição do resíduo da amostra que ficou remanescente no cadinho da análise termogravimétrica. Essa constatação corroborou para que se inferisse o favorável uso do $\mathrm{Mg}(\mathrm{OH})_{2}$ como possível catalisador nas amostras. 


\subsection{Avaliação das análises termogravimétricas}

Nesse item são apresentados os resultados da avaliação de temperaturas da decomposição térmica das amostras estudadas em atmosfera inerte. Os resultados estão dispostos na seguinte ordem: gráfico que relaciona temperatura $X$ variação de massa (TGA); uma imagem aproximada do início de deflexão das curvas do mesmo gráfico e do gráfico de tempo $X$ variação de massa (DTG) para cada grupo de amostra estudada, em atmosfera inerte. $\mathrm{Na}$ imagem 25 , pode-se observar o comportamento da fibra de celulose pura, da amostra I e amostra II quando submetidas a uma taxa de aquecimento de $20 \mathrm{Kelvin} /$ minuto, até $600^{\circ} \mathrm{C}$. 

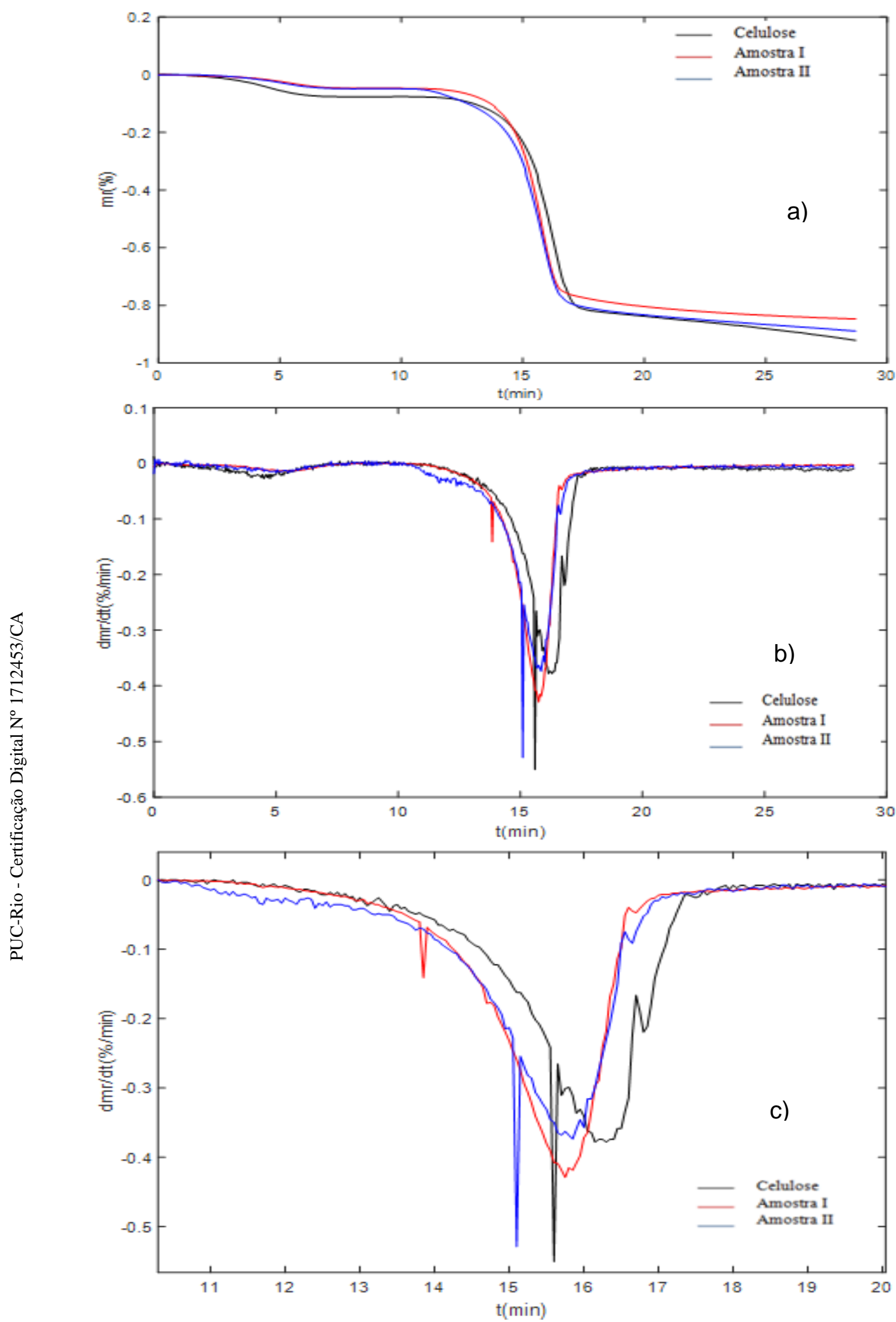

Figura 25: Ensaio termogravimétrico da fibra de celulose sem tratamento, da amostra I e da amostra II, em fluxo de $\mathrm{N}_{2}$. Na imagem a) Curvas de TGA b) a derivada respectiva (DTG) c) curvas de DTG ampliadas 
Os ensaios termogravimétricos indicaram que a celulose (preta) começou a se decompor na faixa de 260 a $320^{\circ} \mathrm{C}$, com perda de massa, atingindo a perda de massa máxima em $351^{\circ} \mathrm{C}$, em 16,2 minutos, com $7,86 \%$ de resíduo sólido a $596^{\circ} \mathrm{C}$. De acordo com Mano et al., (1999) essa temperatura ficaria em torno de $270^{\circ} \mathrm{C}$. Para a amostra I (vermelho) a faixa de temperatura que se iniciou a degradação foi mais alta, 295 a $325^{\circ} \mathrm{C}$, com a taxa máxima de perda de peso em $342,33^{\circ} \mathrm{C}$. Restando $15,25 \%$ de resíduos a $596^{\circ} \mathrm{C}$. No que diz respeito à amostra II (azul) a faixa de temperatura que deu início a degradação foi próxima da temperatura da celulose. A velocidade de degradação máxima se deu a $343,39^{\circ} \mathrm{C}$ em 15,7 minutos. A massa remanescente no cadinho foi em torno de $11,06 \%$ da massa inicial a $597^{\circ} \mathrm{C}$. Entre os três materiais analisados na figura $25 \mathrm{c}$ ), percebe-se que a celulose pura começou a se decompor posterior às duas amostras. Sua decomposição ocorreu com velocidade de $3,82 \mathrm{mg} / \mathrm{min}$, enquanto a velocidade de decomposição da amostra I e II foi 17,68 e 3,94 mg/min respectivamente. Ao contrário do que se esperava não houve um aumento na velocidade de degradação máxima quando se aumentou a quantidade de $\mathrm{Mg}(\mathrm{OH})_{2}$ disponível no tratamento das fibras. Uma das possíveis causas apontadas para essa situação foi apontada por loelovich (2008), que constatou que materiais nanométricos, de uma maneira geral, têm suas características influenciadas por sua elevada área superficial específica, e que essas tendem a se aglomerar em busca de estabilidade. Nas análises de DRX relatadas em tópico próprio, constatou-se o tamanho médio dos cristalitos do precursor $\mathrm{Mg}(\mathrm{OH})_{2}$ em $18.2 \mathrm{~nm}$, o que se enquadra na faixa granulométrica indicada para a nanomateriais. Isso é um fator relevante nesse âmbito, haja vista que a dispersão efetiva de nanopartículas em soluções ainda é um desafio. Outra possível explicação para os diferentes comportamentos observados foi mencionada na pesquisa de Yang et al., (2007), estes relatam que a composição da celulose por longos polímeros de glicose, sem ramificações e com a estrutura ordenada, contribui para uma boa estabilidade térmica. As fibras tratadas com $\mathrm{Mg}(\mathrm{OH})_{2}$ podem ter sofrido alterações estruturais, tornando as amostras mais sensíveis a decomposição térmica em menor tempo. Ainda no que tange as curvas 
DTG (figura 25 b)), pode-se destacar uma variação logo no início das curvas que ocorre a temperaturas inferiores a $260^{\circ} \mathrm{C}$. Esse fato pode estar associado à liberação de alguma espécie volátil gerada durante análise ou provir de alguma contaminação ocorrida na preparação das amostras.

Fenômeno similar foi relatado por Araújo (2011), porém em faixas inferiores a $100^{\circ} \mathrm{C}$ e o material estudado por ele era composto por $\mathrm{MgO}$ dentre outros. Esse comportamento se mostrou mais discreto apenas na curva de DTG na amostra VI, evidenciado na figura $27 \mathrm{c}$ ). Constatação feita por Azwa et al., 2013 contrapõe-se aos resultados obtidos para a amostras I e II, eles estudaram um material com comportamento propício a ser um retardador de chama para um material celulósico. Estes concluíram que compostos inorgânicos com aditivos de hidróxido de magnésio apresentaram bons resultados nessa perspectiva. SierraFernandez et al., (2016) também obtiveram resultados quanto ao uso do hidróxido de magnésio como possível inibidor de degradação da celulose, entretanto a metodologia usada se difere da apresentada nesta pesquisa.

Ainda nesse sentido Li et al., (2017) observaram efeitos benéficos sobre as propriedades retardadoras de chama das fibras celulósicas por incorporação de íons $\mathrm{Mg}^{2+}$, além disso, a capacidade de retardamento de chama foi aumentada à medida que o conteúdo de íons $\mathrm{Mg}^{2+}$ aumentou. Na figura 26, resultados obtidos para amostras tratadas por via solução de $\mathrm{Mg}(\mathrm{OH})_{2}$ podem ser observados. 


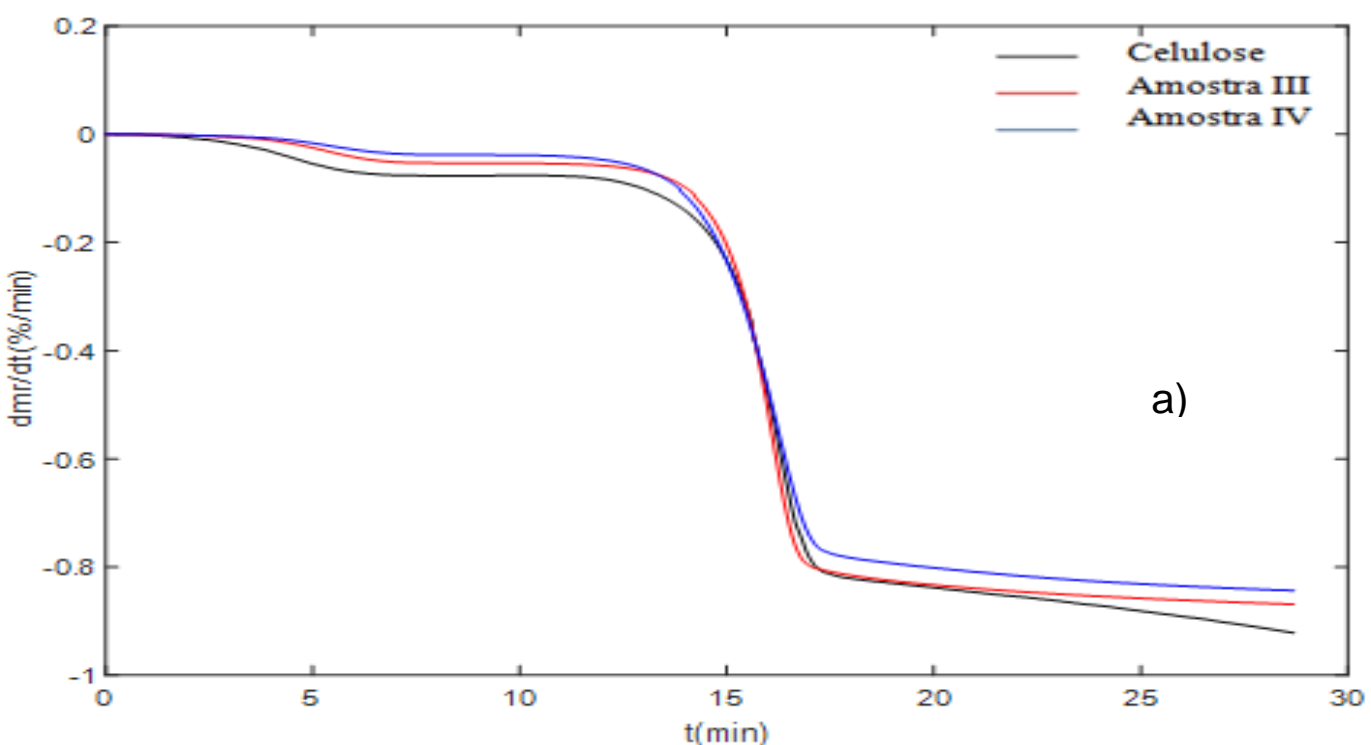

ل्]
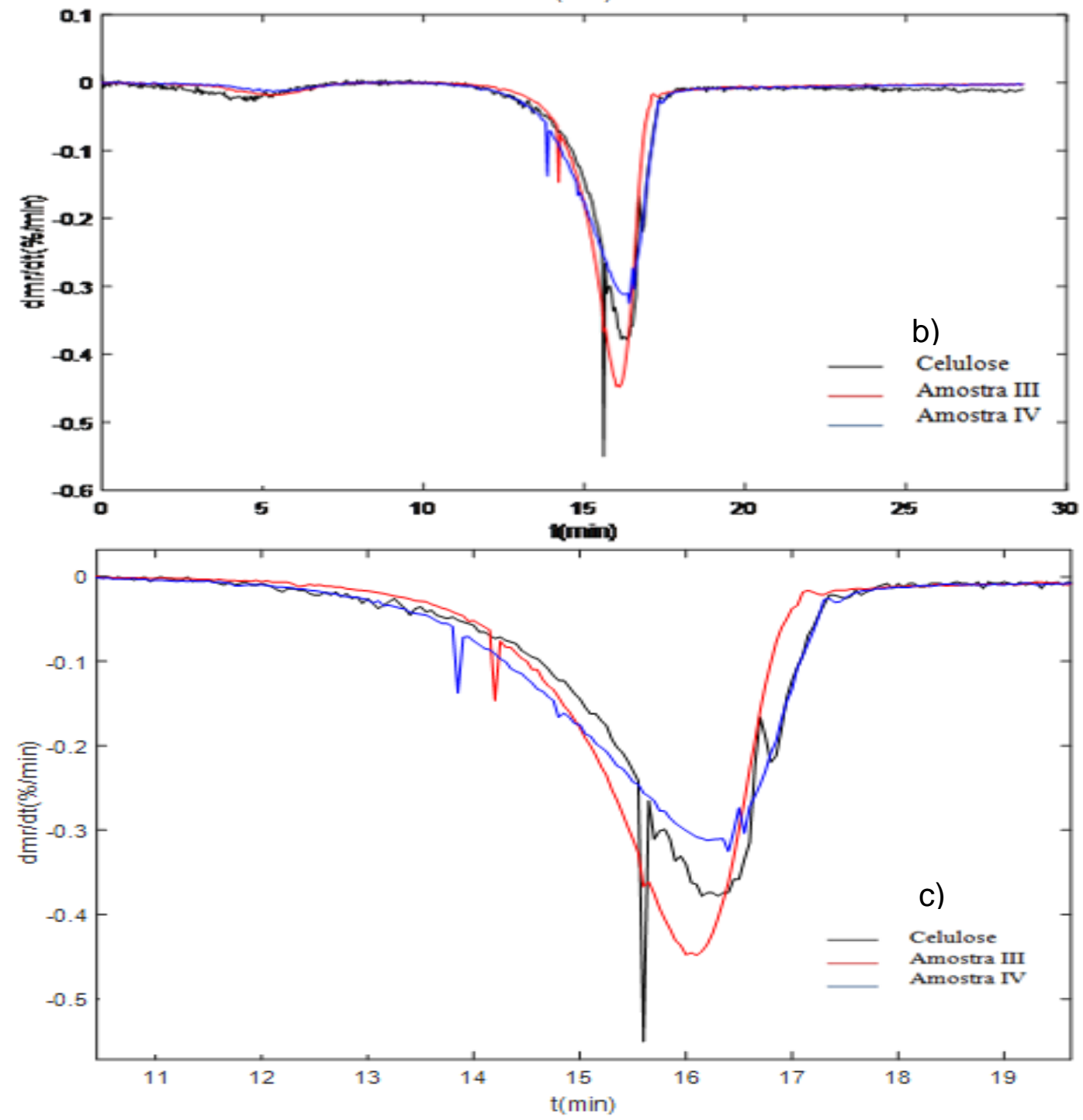

Figura 26: Ensaio termogravimétrico da celulose sem tratamento, da amostra III e da amostra IV em fluxo de $\mathrm{N}_{2}$. Na imagem a) Curvas termogravimétricas, b) as derivadas das curvas termogravimétricas c) as curvas de DTG ampliadas. 
Os resultados das análises termogravimétricas destas amostras, permitiram constatar que a amostra III iniciou a degradação na faixa de 300 a $340^{\circ} \mathrm{C}$. A velocidade máxima de perda de massa ocorreu em $347^{\circ} \mathrm{C}$, no instante 16 minutos. Restando $13,14 \%$ de resíduos a $597^{\circ} \mathrm{C}$. No que diz respeito a amostra IV a faixa de temperatura que deu início a degradação foi 240 a $300^{\circ} \mathrm{C}$, e com a taxa máxima de perda de peso em $349^{\circ} \mathrm{C}$. Seu resíduo foi de $15,66 \%$ a $596^{\circ} \mathrm{C}$. Em relação a velocidade de degradação dos materiais, expostos o gráfico da figura 26 b) a amostra III obteve uma velocidade de degradação máxima de $17,64 \mathrm{mg} / \mathrm{min}$ no instante de 16 minutos, e a massa residual aos $595^{\circ} \mathrm{C}$ de $13,14 \%$. A amostra IV teve um comportamento mais brando no aspecto velocidade de degradação máxima, esta alcançou 12,64 mg/min, no instante 16,1 minutos na temperatura de $349,81^{\circ} \mathrm{C}$, com massa residual de $15,66 \%$ a $596^{\circ} \mathrm{C}$. No que tange aos resultados sobre a variação de massa em função do tempo, percebe-se no gráfico a) que não houve variações significativas no comportamento das diferentes amostras. No gráfico b) os resultados indicam que para um mesmo tempo de reação, nota-se uma velocidade de degradação maior para a amostra III, que foi tratada com percentual menor de solução de $\mathrm{Mg}(\mathrm{OH})_{2}$ e em temperaturas similares entre as 3 amostras. Isso evidencia uma certa independência da temperatura no tempo correspondente para que a velocidade de degradação varie, sugerindo que a quantidade de $\mathrm{Mg}(\mathrm{OH})_{2}$ adsorvido é que determina e interfere no comportamento das fibras nesse sentido. $\mathrm{Na}$ sequência os resultados obtidos a partir das análises termogravimétricas da amostra V e VI podem ser observados. 

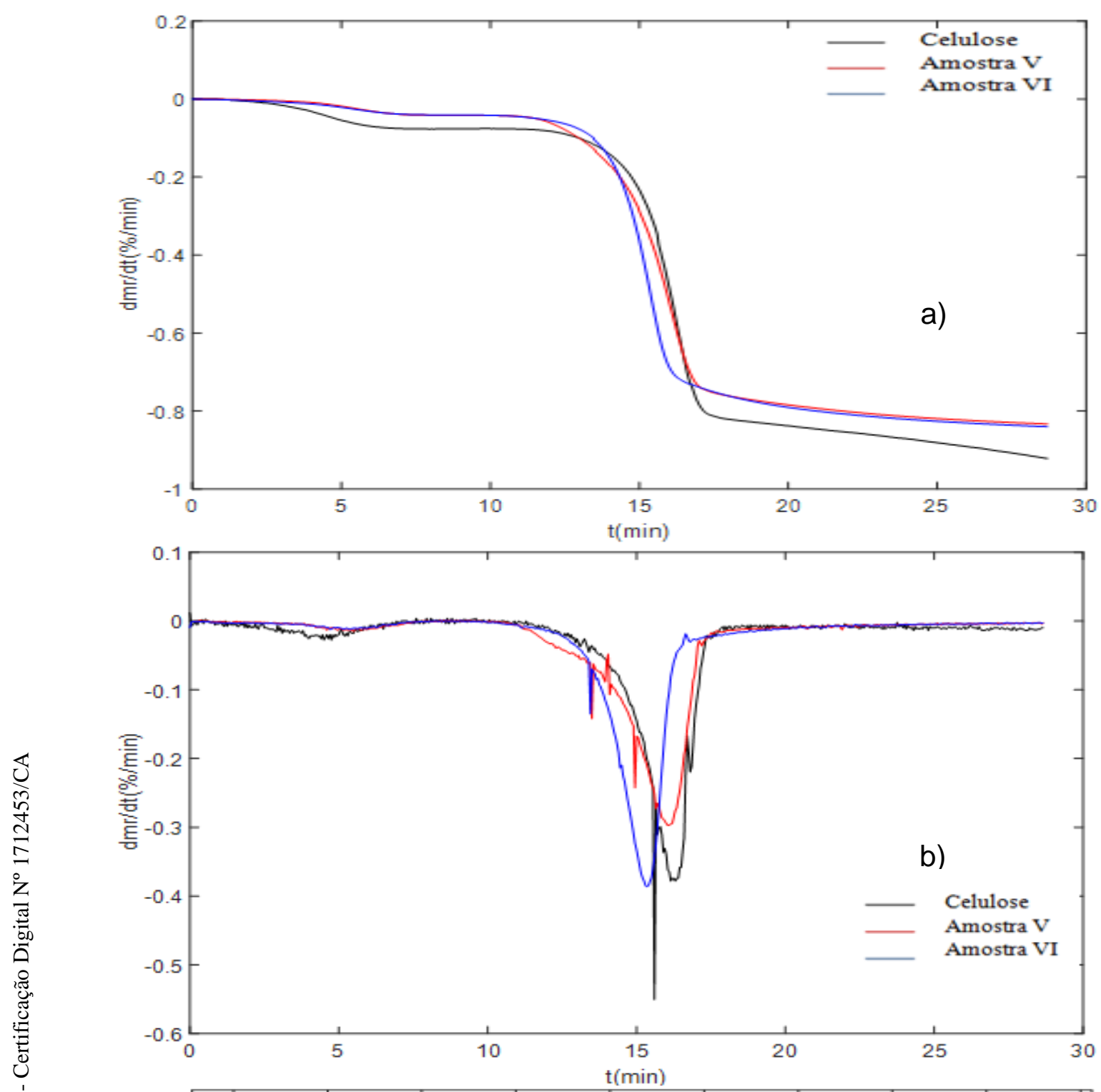

نُ

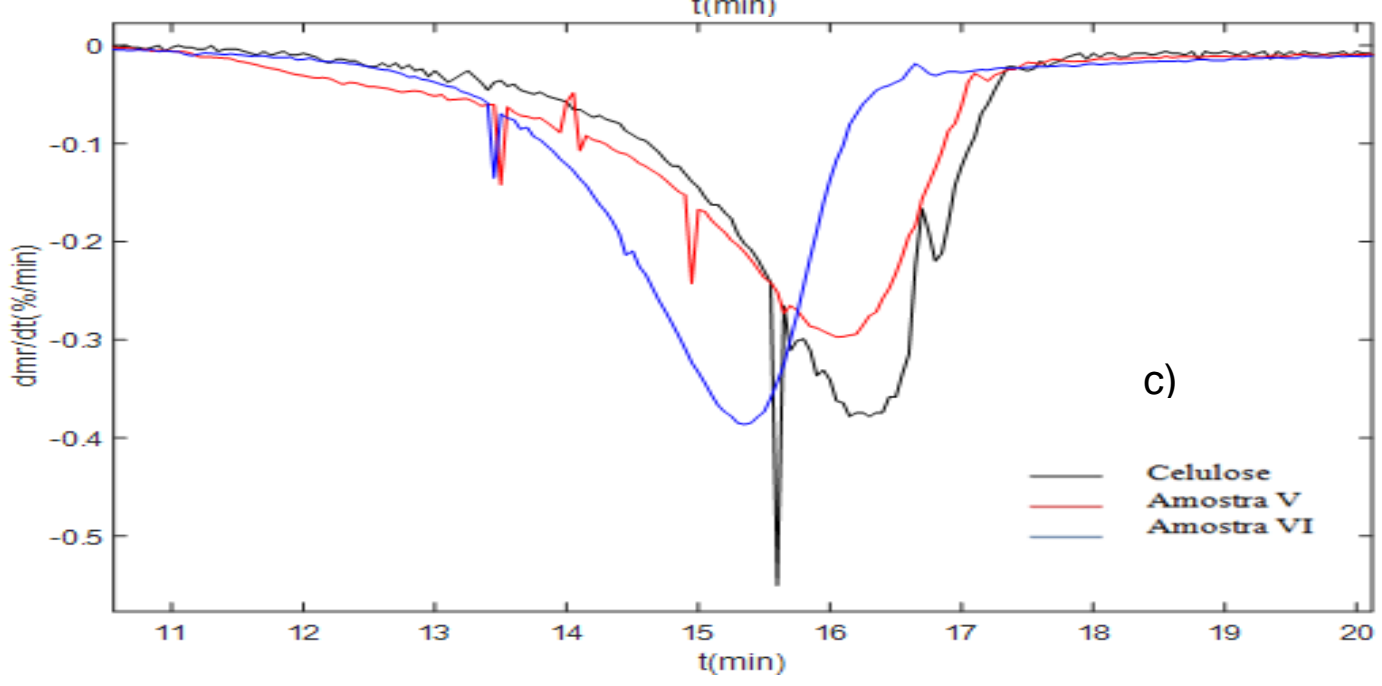

Figura 27: Ensaio termogravimétrico da fibra de celulose, da amostra $\mathrm{Ve}$ $\mathrm{VI}$ em fluxo de $\mathrm{N}_{2}$. Na imagem a) as curvas termogravimétricas, b) as derivadas das curvas termogravimétricas c) as curvas de DTG ampliadas. 
Com as análises termogravimétricas que as amostras $\mathrm{V}$ e $\mathrm{VI}$ foram submetidas, inferiu-se que a perda de massa da amostra $V$ (vermelha) teve início entre 270 e $310^{\circ} \mathrm{C}$. Esta teve a taxa máxima de perda de peso em $348,69^{\circ} \mathrm{C}$, no tempo correspondente de 16,05 minutos. Com saldo de massa remanescente de $16,69 \%$ a $596^{\circ} \mathrm{C}$. No que tange à amostra $\mathrm{VI}$, a faixa de temperatura que se iniciou a degradação foi de 310 a $345^{\circ} \mathrm{C}$, a taxa máxima de perda de peso se deu a $333,56^{\circ} \mathrm{C}$, no tempo correspondente de 15,3 minutos. Seu resíduo sólido remanescente após a análise termogravimétrica foi de $15,99 \%$ a $596^{\circ} \mathrm{C}$. Na figura 27 b) 0 gráfico indica a velocidade de perda de massa por minuto, para a amostra $\mathrm{V}$ e $\mathrm{VI}$, as velocidades se apresentaram em 11,98 e 16,24 mg/min respectivamente. A metodologia empregada neste caso facilitou a interação dos materiais presentes nesta amostra e podem estar corroborando com reações de desidratação destas e, consequentemente, potencializar a sua degradação térmica em menor tempo reacional. $\mathrm{O}$ comportamento térmico das amostras $\mathrm{V}$ e $\mathrm{VI}$ evidenciam a influência da adição de carga inorgânica na estabilidade térmica da fibra de celulose tratada. São encontrados na literatura estudos que compartilham dos indícios observados nesta.

Pütün et al., (2010) revelaram o bom desempenho do $\mathrm{MgO}$ como catalisador na degradação térmica com ausência de ambiente oxidativo em sementes de algodão. Em contrapartida, Kitamura et al., (1996) relatam em seus resultados que a redução de solubilidade do hidróxido de magnésio com o aumento da temperatura leva a um estado de supersaturação que rapidamente se desfaz em uma precipitação intensa, o que nesse caso prejudicaria a adsorção das partículas, já que haveria menos cátions livres. Seguidamente amostras sintetizadas a partir de apenas contato físico (maceradas) foram analisadas pela técnica presente. 

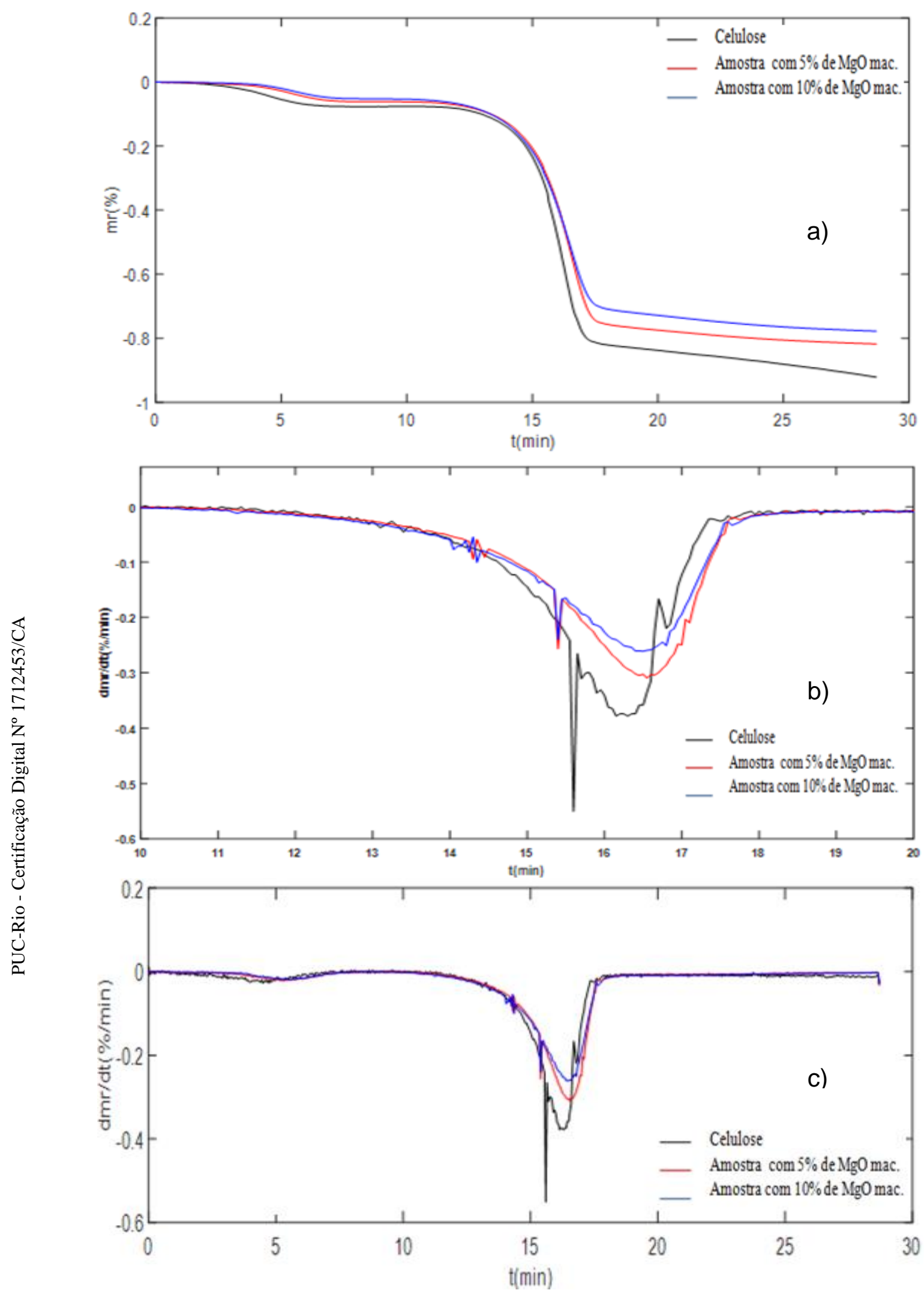

Figura 28: Ensaio termogravimétrico da celulose pura, da amostra com $5 \%$ de $\mathrm{MgO}$ e da amostra com $10 \%$ de $\mathrm{MgO}$ macerados, em fluxo de $\mathrm{N}_{2}$. $\mathrm{Na}$ imagem a) Curvas termogravimétricas, b) as derivadas das curvas termogravimétricas e c) as DTG ampliadas. 
Nesta última análise termogravimétrica, se observar que a amostra com $5 \%$ de $\mathrm{MgO}$ macerado (vermelho) a faixa de temperatura que se iniciou a degradação foi 295 a $350^{\circ} \mathrm{C}$. A taxa máxima de perda de peso ocorreu em $356^{\circ} \mathrm{C}$. Restando $18,22 \%$ de resíduos a $596^{\circ} \mathrm{C}$. No que diz respeito à amostra com $10 \%$ de $\mathrm{MgO}$ macerado (azul) a faixa de temperatura que deu início a degradação foi mais alta que a da celulose, porém muito próxima da faixa de degradação da outra amostra, 290 a $345^{\circ} \mathrm{C}$, com a taxa máxima de perda de peso também em $356^{\circ} \mathrm{C}$. Seu resíduo sólido foi de $22,19 \%$ a $597^{\circ} \mathrm{C}$. Em relação à velocidade de degradação máxima dos materiais, (figura 28 b)) a amostra com $5 \%$ de $\mathrm{MgO}$ alcançou $12,45 \mathrm{mg} / \mathrm{min}$ em $356^{\circ} \mathrm{C}$ no instante de 16,45 minutos, e a massa residual aos $595^{\circ} \mathrm{C}$ foi de $18,22 \%$. E a amostra com $10 \%$ de $\mathrm{MgO}$ atingiu a velocidade máxima de 10,84 $\mathrm{mg} / \mathrm{min}$, no instante 16,4 na temperatura também de $356,09^{\circ} \mathrm{C}$, com massa residual de $22,19 \%$ a $596^{\circ} \mathrm{C}$. Nessas análises pode se inferir que o efeito de aceleração da degradação em menor tempo observados em outras amostras se relacione com o processo de metodologia aplicado, sugerindo que a interação dos materiais não acontece por via seca, contato sólido-sólido, e sim via adsorção de cátions presentes na solução. Alguns estudos têm investigado efeitos similares, como Carvalho (2016) que relatou o óxido de magnésio hidratado utilizado como aditivo de uma matriz de celulose avaliada atribuiu maior estabilidade térmica ao material, o que corrobora com os resultados obtidos para as amostras maceradas com $\mathrm{MgO}$, embora os trabalhos se distingam. Diante dos resultados das análises térmicas das amostras V, VI e maceradas na porcentagem 5 e 10\%, cabe ressaltar que quando se diminuiu a área de contato entre os materiais, houve um prejuízo na eficiência do processo, haja vista que menos cátions de magnésio estiveram disponíveis no sistema. Na tabela 7 , é possível verificar a variação de massa das amostras que foram submetidas à análise termogravimétrica em atmosfera inerte. 
Tabela 7: Variação de massa em atmosfera inerte

\begin{tabular}{lccl}
\hline Material & $\begin{array}{l}\text { Massa de entrada } \\
(\mathrm{mg})\end{array}$ & $\begin{array}{l}\text { Massa de saída } \\
(\mathrm{mg})\end{array}$ & Perda $(\%)$ \\
\hline Celulose pura & 10,10 & 0,79 & 92,14 \\
\hline Amostra I & 41,20 & 6,29 & 84,75 \\
\hline Amostra II & 10,70 & 1,18 & 88,94 \\
\hline Amostra III & 39,40 & 5,18 & 86,86 \\
\hline Amostra IV & 41,00 & 6,42 & 84,34 \\
\hline Amostra V & 40,30 & 6,72 & 83,31 \\
\hline Amostra VI & 42,20 & 6,75 & 84,01 \\
\hline $\begin{array}{l}\text { Celulose + 5\% de } \\
\text { MgO macerado }\end{array}$ & 41,00 & 7,47 & 81,78 \\
\hline $\begin{array}{l}\text { Celulose + 10\% } \\
\text { de MgO macerado }\end{array}$ & 41,60 & 9,23 & 77,81 \\
\hline
\end{tabular}

Por meio da tabela 7, é possível quantificar as perdas de massa em cada evento de decomposição térmica das amostras em atmosfera inerte. A maior fração do material das amostras é constituída de celulose. Por este motivo, os percentuais de perda de massa observados devem ter o resultado da própria fibra de celulose sem tratamento como parâmetro de comparação.

Pode-se observar que a maior perda de massa foi da celulose sem tratamento, nas demais amostras as perdas ficaram entre 77 e $88 \%$ o que sugere que a massa remanescente no cadinho tinha como constituinte não apenas celulose, mas também $\mathrm{Mg}(\mathrm{OH})_{2}$ e $\mathrm{MgO}$ a depender do tratamento empregado. O que corrobora com uma potencial aplicação dessas cargas como catalisadores heterogêneos (possível separar eficientemente o produto formado do catalisador). A seguir, um estudo cinético será discutido baseando nos resultados obtidos por meio das análises termogravimétricas. 


\subsection{Análise cinética de decomposição}

O conhecimento dos parâmetros cinéticos envolvidos nas reações de termoconversão são fundamentais para o projeto e otimização do processo empregado. Neste trabalho foram obtidos dados experimentais da decomposição térmica por meio de análises termogravimétricas sob fluxo contínuo de nitrogênio. Para determinar a energia de ativação da reação de decomposição usando os resultados dos ensaios termogravimétricos foi usada a técnica desenvolvida por Speyer (1993), os parâmetros cinéticos de decomposição térmica foram estimados a partir deste método. A amostra $\mathrm{VI}$ e a celulose pura foram escolhidas para se contrapor os resultados haja vista que aquela foi a que teve melhor desempenho no que tange a velocidade máxima de decomposição em menor tempo reacional dentre as demais amostras tratadas. Os dados termogravimétricos de degradação da celulose e da amostra tratada VI, como indicada nas figuras 29 e 30, foram aproximados a um polinômio de ordem 7, com ajuda do software Matlab. Estes polinômios apresentaram um bom ajuste, mostrando em ambos os casos uma correlação próxima de 1. Segue abaixo a análise cinética da celulose pura.

\subsubsection{Análise cinética de decomposição da fibra de celulose sem tratamento.}

A partir dos dados ajustados de degradação dos materiais da celulose pura e da amostra $\mathrm{VI}$, realizou se a análise cinética da degradação, objetivando a determinação da energia de ativação do presente processo. Considerando-se uma reação de primeira ordem como indicado na técnica desenvolvida por Speyer (1993), descrito no item 3.2.7.

O resultado destas análises, como mostrados na figura 29, para a celulose sem tratamento, e figura 30 para a amostra VI, precisaram de um refinamento dos dados para o qual foi desenvolvido um programa com ajuda do software matlab, que consistiu em restringir variações nos eixos $x$ e y para serem aceitos e comporem o novo grupo de dados. 


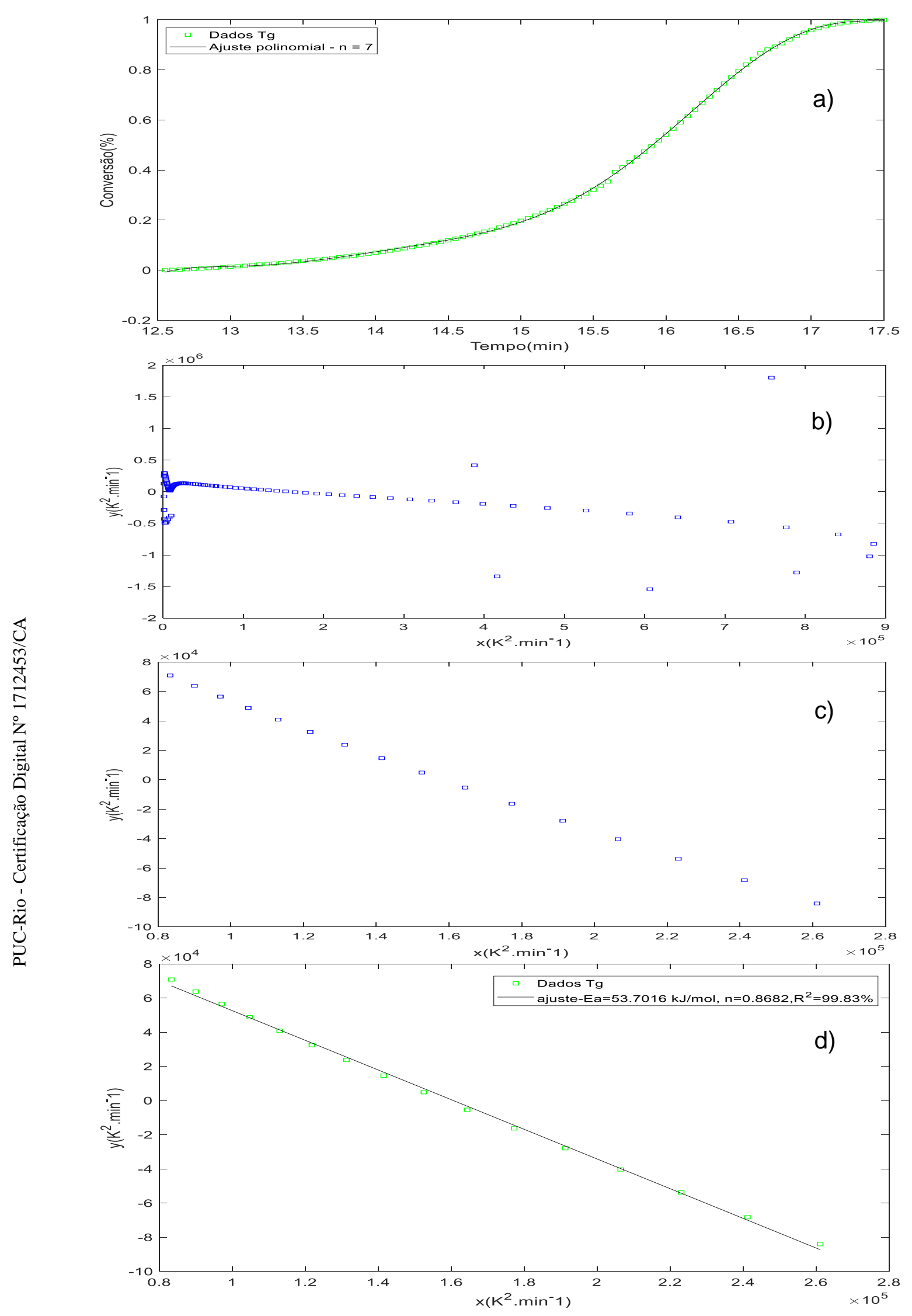

Figura 29: Ajuste dos dados termogravimétricos da celulose pura; curva sem refinamento para determinar Ea da reação de degradação; dependência experimental da energia de ativação da celulose sem tratamento com o grau de conversão das reações de decomposição. 
$\mathrm{Na}$ literatura estudada os valores obtidos para energia de ativação da celulose ainda divergem muito, na medida em que há diversos métodos de se alcançar esse valor. Zanatta e colaboradores em 2012, estimaram os parâmetros cinéticos de decomposição térmica com 0 método proposto por Flynn-Wall-Ozawa (FWO). Eles testaram diferentes modelos para descrever a taxa de reação: nucleação e crescimento, reação química generalizada e de primeira ordem. Os resultados obtidos para energia de ativação da celulose foram:

- de 129.58 - $149.35 \mathrm{~kJ} \mathrm{~mol}^{-1}$, pelo método de Flynn-Wall-Ozawa;

- de $160.10 \mathrm{~kJ} \mathrm{~mol}^{-1}$, pelo método de reação química de primeira ordem;

- de $161.09 \mathrm{~kJ} \mathrm{~mol}^{-1}$, pelo método de reação química de ordem generalizada;

- de $136.69 \mathrm{~kJ}^{\mathrm{mol}}{ }^{-1}$, pelo método de nucleação de ordem generalizada.

No estudo em questão, o método que melhor representou a cinética de decomposição da celulose foi o da nucleação de ordem generalizada. (Zanatta et al., 2012).

Costa e colaboradores (2018) também obtiveram dados cinéticos para a celulose: energia de ativação de $430,41 \mathrm{~kJ} \cdot \mathrm{mol}^{-1}$, durante a decomposição da amostra, usando fator pré-exponencial de 3,81.1037 $\min ^{-1}$ e uma ordem de reação de 1,97. A energia de ativação encontrada nessa pesquisa se difere da literatura consultada, uma possível explicação pode estar na matéria prima e na técnica usada para se determinar a energia de ativação

\subsubsection{Análise cinética de decomposição da amostra VI}



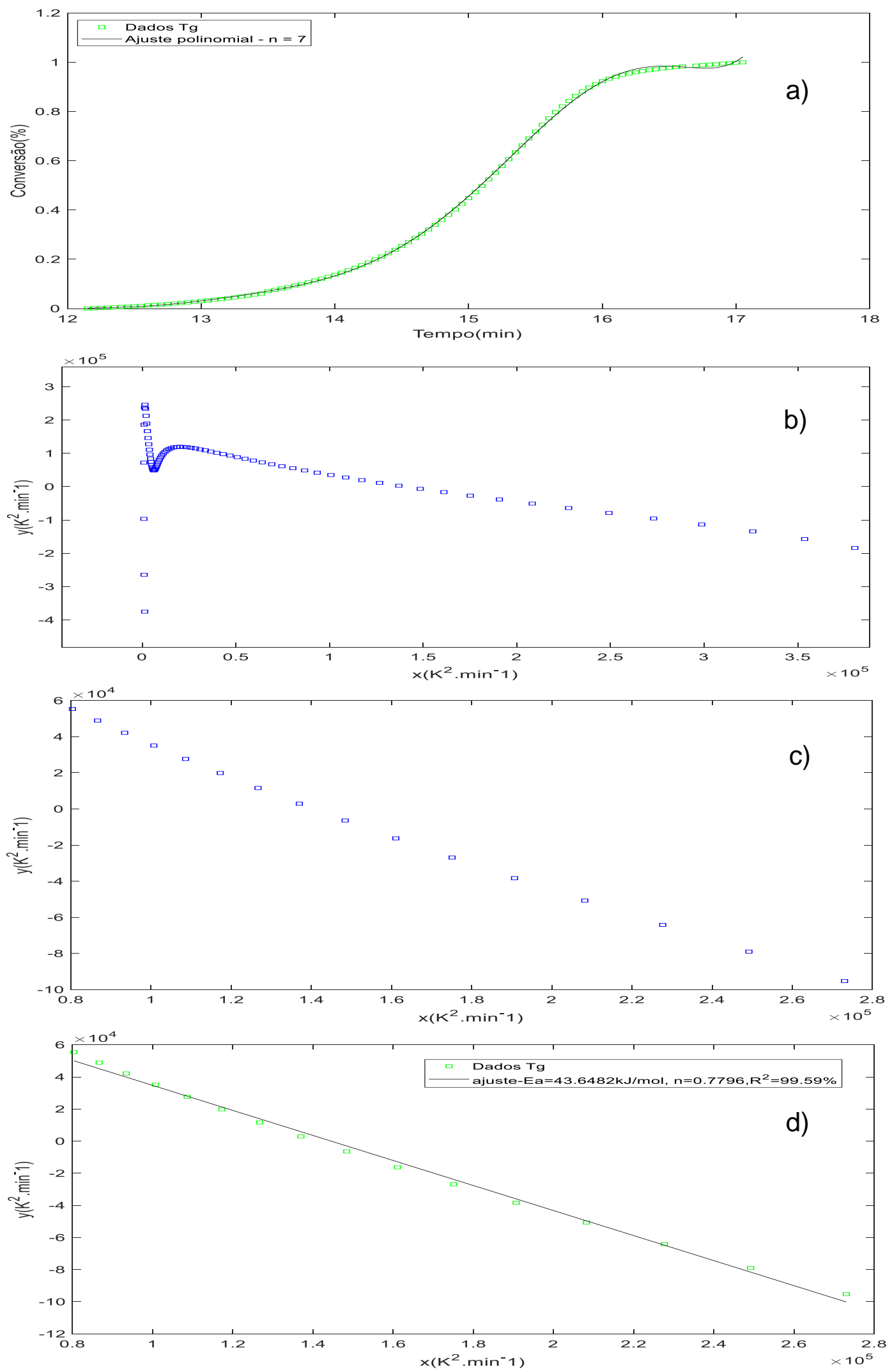

Figura 30: Ajuste dos dados termogravimétricos da amostra VI; curva sem refinamento para determinar Ea da reação de degradação; dependência experimental da energia de ativação da amostra sem tratamento com o grau de conversão das reações de decomposição. 
A o método exposto nas figuras 29 e 30, permitiram determinar as energias de ativação das duas amostras, representadas pelos pendentes das linhas retas em cada caso. No primeiro caso o valor da energia de ativação foi $E a=53,702 \mathrm{~kJ} / \mathrm{mol}$, obtido na fase que figura $29 \mathrm{~d}$ ) ilustra, correspondente a celulose pura, e no caso da amostra VI o valor obtido da $\mathrm{Ea}=43,64 \mathrm{~kJ} / \mathrm{mol}$, a partir da figura $30 \mathrm{~d}$ ).

No caso do material tratado VI, este apresentou um valor inferior de Ea, o que representaria um menor consumo de energia para ocorrer a degradação térmica da amostra, o que sugere o efeito catalítico dos íons de magnésio adsorvidos na celulose. 


\section{Conclusão}

Por meio das caracterizações do DRX foi possível identificar o tamanho médio dos cristalitos dos materiais precursores e os picos característicos respectivos, indicando assim a presença destes nos materiais sintetizados;

As micrografias de MEV com EDS permitiram que se inferisse a compatibilidade entre os materiais uma vez que a partir dos mapas constatou-se o magnésio bem dispersos nas fibras. A exceção foi da amostra macerada com $10 \%$ de $\mathrm{MgO}$ porquanto identificou-se aglomerados dos óxidos de magnésio entre as fibras;

Acerca do comportamento térmico das amostras, os resultados das micrografias corroboram com a sugestão que o efeito acelerador de degradação que $\mathrm{o} \mathrm{Mg}(\mathrm{OH})_{2}$ imprimiu nas fibras não vieram a partir da interação sólido-sólido e sim via adsorção de cátions de magnésio presentes na solução;

As avaliações termogravimétricas em atmosfera inerte evidenciaram que as amostras tratadas sofreram alterações na estabilidade térmica quando contrapostas com a fibra de celulose sem tratamento;

Amostra $\mathrm{VI}$ teve o melhor resultado em termos de aceleração da degradação em menor tempo. Visto isso, foi feita uma análise cinética dessa amostra e da fibra de celulose sem tratamento. Os resultados indicaram que a celulose e a amostra VI apresentaram valores de 53,702 $\mathrm{kJ} / \mathrm{mol}$ e de $43,64 \mathrm{~kJ} / \mathrm{mol}$ para energia de ativação. Isso representaria um menor consumo de energia para ocorrer a degradação da amostra VI, confirmando a provável potencialidade do efeito catalítico dos cátions de magnésio adsorvidos na celulose;

O sódio é um possível interferente no desempenho do processo no que tange ao efeito catalítico observado como foi observado na amostra III e IV; 
Os resultados observados foram apropriados para sugerir a continuação dos estudos no sentido da utilização desse material em processos que visem acelerar a degradação térmica da celulose e podem fundamentar investigações futuras.

\subsection{Sugestões para trabalhos futuros}

Realizar a síntese dos precursores sem a presença do hidróxido de sódio, possivelmente usando o hidróxido de amônia ou ainda o próprio magnésio PA;

Analisar a energia de ativação (Ea) e a ordem (n) para diferentes taxas a partir dos mesmos materiais utilizando o método de Kissinger ou similares;

Analisar o efeito de outros cátions alcalinos e de metais de transição no tratamento das fibras;

Determinar a concentração de magnésio adsorvido nas fibras e realizar o estudo cinético de adsorção desses cátions visando a otimização do tempo de contato. 


\section{Referências bibliográficas}

ALMACO. Setor de compósitos registra segundo ano consecutivo de crescimento. 2018. Disponível em: <http://almaco.org.br/2018/12/03/setor-de-compositos-registra-segundoano-consecutivo-de-crescimento/>. Acesso em: 18 set. 2018.

AMARAL, L. F., SALOMÃO, R., FROLLINI, E., \& PANDOLFELLI, V. C. Mechanisms of magnesium oxide hydration. Cerâmica, v. 53, n. 328, p. 368-372, 2007.

ANIRUDHAN, T. S.; CHRISTA, J.; DEEPA, J. R. Extraction of melamine from milk using a magnetic molecularly imprinted polymer. Food chemistry, v. 227, p. 85-92, 2017.

ARAÚJO, D. R. Síntese e caracterização de óxido de magnésio obtido por diferentes técnicas e sua aplicação na produção de Biodiesel. Dissertação de Mestrado. Universidade de Brasília, 2011.

ARAUJO, J. R.; WALDMAN, W. R.; DE PAOLI, M. A. Thermal properties of high-density polyethylene composites with natural fibres: Coupling agent effect. Polymer degradation and stability, v. 93, n. 10, p. 1770-1775, 2008.

ASSOCIAÇÃO BRASILEIRA DE METALURGIA, MATERIAIS E MINERAÇÃO, 67ำ, Rio de Janeiro, 2012.

ASSUMPÇÃO, R. M. V., PINHO, M. R. R., CAHEN, R., \& PHILIPP, P. Polpação química. Celulose e papel. Tecnologia de fabricação de pasta celulósica, v. 1, 1988. 
AZWA, Z. N., YOUSIF, B. F., MANALO, A. C., \& KARUNASENA, W. A review on the degradability of polymeric composites based on natural fibres. Materials \& Design, v. 47, p. 424-442, 2013.

BAGLIONI, P., CHELAZZI, D., GIORGI, R., \& POGGI, G. Colloid and materials science for the conservation of cultural heritage: 2013, Cleaning, consolidation, and deacidification. Langmuir.

BAGLIONI, P., \& GIORGI, R. Soft and hard nanomaterials for restoration and conservation of cultural heritage. 2006, p. 293-303. Soft Matter

BARUFFALDI, R.; OLIVEIRA, M. N. Fundamentos de Tecnologia de Alimentos. São Paulo: Atheneu, 1998.

BERNARDO-GUSMÃO, K.; PERGHER, S. B.; SANTOS, E N. DOS. A panorama of catalysis in brazil in the last $\mathbf{4 0}$ years. Química Nova, v. 40, n. 6, p. 650-655, 2017.

BLEDZKI, A. K.; GASSAN, J. Composites reinforced with cellulose based fibres. Progress in polymer science, v. 24, n. 2, p. 221-274, 1999.

BORDES, PERRINE; POLLET, ERIC; AVÉROUS, LUC. Nanobiocomposites: biodegradable polyester/nanoclay systems. Progress in Polymer Science, v. 34, n. 2, p. 125-155, 2009.

BROWN, R. M. J., \& SAXENA, I. M. Cellulose: 2007, Molecular and Structural Biology. Library.

BUSACCA, C. A., FANDRICK, D. R., SONG, J. J., \& SENANAYAKE, C. $\mathrm{H}$.. The growing impact of catalysis in the pharmaceutical industry. Advanced Synthesis \& Catalysis, v. 353, n. 11-12, p. 1825-1864, 2011. 
CALLISTER, W., \& RETHWISCH, D. Materials science and engineering: an introduction. Materials Science and Engineering, 7th ed., Vol. 94, 2007. New York: John Wiley \& Sons.

CAMARGOS, CAMILLA HENRIQUES MAIA DE. Compósitos de Nanocristais e Nanofibrilas de Celulose: Preparação, Caracterização e Potenciais Aplicações em Processos de Restauração de Documentos e Obras de Arte sobre Papel. Tese de Mestrado. Universidade Federal de Minas Gerais, Instituto de Ciências Exatas: Departamento de Química, 2016.

CARVALHO, THAÍS. Preparação e caracterização de compósitos com matriz de poliuretano e híbridos fibrosos modificados com óxido de magnésio hidratado. Tese de Doutorado. Universidade de São Paulo, 2016.

CATTI, M., FERRARIS, G., HULL, S., \& PAVESE, A. Static compression and $\mathrm{H}$ disorder in brucite, $\mathrm{Mg}(\mathrm{OH})_{2}$, to $11 \mathrm{GPa}$ : a powder neutron diffraction study. Physics and Chemistry of Minerals, v. 22, n. 3, p. 200206, 1995.

CERQUEIRA, DANIEL ALVES. Síntese e caracterização de misturas poliméricas contendo acetato de celulose: aproveitamento de resíduos da cana-de-açúcar, 2009.

CERQUeIRA, D. A., RODRIGUES FILHO, G., CARVALHO, R. D. A., \& VALENTE, A. J. Caracterização de acetato de celulose obtido a partir do bagaço de cana-de-açúcar por 'H-RMN. Polímeros: Ciência e Tecnologia, v. 20, n. 2, 2010.

CHAWLA, K. K. Composite-Materials-Science and Engineering. New York: Springer-Verlag, 1987. 
CHEN, HONGYAN; MIAO, MENGHE; DING, XIN. Influence of moisture absorption on the interfacial strength of bamboo/vinyl ester composites. Composites Part A: Applied Science and Manufacturing, v. 40, n. 12, p. 2013-2019, 2009.

CHEN, WAI-FAH (Ed.). Limit analysis and soil plasticity. Elsevier, 2013.

CHINGA-CARRASCO, Gary. Cellulose fibres, nanofibrils and microfibrils: the morphological sequence of MFC components from a plant physiology and fibre technology point of view. Nanoscale research letters, v. 6, n. 1, p. 417, 2011.

CHRISTENSEN, M., KUTZKE, H., \& HANSEN, F. K. New materials used for the consolidation of archaeological wood-past attempts, present struggles, and future requirements. Journal of Cultural, 2012.

Cintra, J. S. A., PedrozA, G. A. G., PORTElA, M. N., Silvany, T. D. C., SANTOS, L. C. L., \& LOBATO, A. K. D. C. L. Influência do tempo de reação na produção de biodiesel via catálise heterogênea. Holos, v. 1, p. 195-204, 2017.

CORDEIRO, C. S., SILVA, F. R., WYPYCH, F., \& RAMOS, L. P. Catalisadores heterogêneos para a produção de monoésteres graxos (biodiesel). Química nova, v. 34, n. 3, p. 477-486, 2011.

CORREIA, F. M. Análise de distúrbios de compactação de cavacos de eucalipto em digestores contínuos fase vapor. 2010. Tese de Doutorado. Tese (Mestrado Profissional em Celulose e Papel)Universidade Federal de Viçosa, 132p.

CORREIA, NUNO FILIPE DE OLIVEIRA. Produção e caracterização de dispositivos electrocrómicos em substratos à base de celulose. 2008. Tese de Doutorado. FCT-UNL. 
CUENYA, BEATRIZ ROLDAN. Synthesis and catalytic properties of metal nanoparticles: Size, shape, support, composition, and oxidation state effects. Thin Solid Films, v. 518, n. 12, p. 3127-3150, 2010.

D’ALMEIDA, MLO. Celulose e papel. Tecnologia da fabricação da pasta celulósica, v. 1, 1988.

DAMÁSIO, FÁBIO RAIMUNDO. Influência da variabilidade dos materiais compósitos na resposta dinâmica de estruturas laminadas. 2015. Tese de Doutorado. Instituto Superior de Engenharia de Lisboa.

DARDER, MARGARITA; ARANDA, PILAR; RUIZ-HITZKY, EDUARDO. Bionanocomposites: a new concept of ecological, bioinspired, and functional hybrid materials. Advanced Materials, v. 19, n. 10, p. 13091319, 2007.

DEDAVID, BERENICE ANINA; GOMES, CARMEM ISSE; MACHADO, GIOVANNA. Microscopia eletrônica de varredura: aplicações e preparação de amostras: materiais poliméricos, metálicos e semicondutores. Edi PUCRS, 2007.

DIAS, F. R. F.; FERREIRA, V. F.; CUNHA, A. C. Diferentes Tipos de Catálise em Síntese Orgânica; Tipos de Catálise em Síntese Orgânica. v. 4 , n. 6 , p. $840-871,2012$.

DITTENBER, DAVID B.; GANGARAO, HOTA VS. Critical review of recent publications on use of natural composites in infrastructure. Composites Part A: Applied Science and Manufacturing, v. 43, n. 8, p. 1419-1429, 2012.

EINCHHORN, S. J., DUFRESNE, A., ARANGUREN, M. M., CAPADONA, J. R., ROWAN, S. J., WEDER, C., ... \& VEIGEL, S. Review: current international research into cellulose nanofibres and composites. J. Mater. Sci, v. 45, p. 1-33, 2010. 
FARUK, O., BLEDZKI, A. K., FINK, H. P., \& SAIN, M. Biocomposites reinforced with natural fibers: 2000-2010. Progress in polymer science, v. 37, n. 11, p. 1552-1596, 2012.

FERNANDEZ-GARCIA, M., MARTINEZ-ARIAS, A., HANSON, J. C., \& RODRIGUEZ, J. A. Nanostructured oxides in chemistry: characterization and properties. Chemical Reviews, v. 104, n. 9, p. 40634104, 2004.

FERREIRA, VITOR FRANCISCO; ROCHA, DAVID RODRIGUES E SILVA, FERNANDO DE CARVALHO DA. Potencialidades e oportunidades na química da sacarose e outros açúcares. Quím. Nova [online]. 2009, vol.32, n.3, p.623-638.

FIGUEIREDO JUNIOR, J. C. D. Química Aplicada à conservação e restauração de bens culturais: uma introdução. Belo Horizonte: São Jerônimo, 2012.

FLOREZ, ELIZABETH; FUENTEALBA, PATRICIO; MONDRAGÓN, FANOR. Chemical reactivity of oxygen vacancies on the $\mathrm{MgO}$ surface: Reactions with $\mathrm{CO}_{2}, \mathrm{NO}_{2}$ and metals. Catalysis Today, v. 133, p. 216-222, 2008.

GAY, D.; HOA, S.V. Composite materials: design and applications. CRC Press, 2007. $50 \mathrm{p}$.

GAGNON, G. R.; RIGDAL, R.; SCHUAL-BERKE, J.; BILODEAU, M.; BOUSFIELD, D. W. The effect of nano-fibrillated cellulose on the mechanical properties of polymer films. 2010.

GARCIA, L.R.A; BRANDÃO, P.R.G; LIMA, R.M.F. Magnesita. CETEM, p. 509-510, 2008. 
GIORGI, R., DEI, L., CECCATO, M., SCHETTINO, C., \& BAGLIONI, P. Nanotechnologies for conservation of cultural heritage: 2002, Paper and canvas deacidification.

GÓMEZ-ORTÍZ, N., DE LA ROSA-GARCÍA, S., GONZÁLEZ-GÓMEZ, W., SORIA-CASTRO, M., QUINTANA, P., OSKAM, G., \& ORTEGAMORALES, B. Antifungal coatings based on $\mathrm{Ca}(\mathrm{OH})_{2}$ mixed with $\mathrm{ZnO} / \mathrm{TiO}_{2}$ nanomaterials for protection of limestone monuments. 2013, ACS Applied Materials and Interfaces.

GÓMEZ-VILLALBA, L. S., LÓPEZ-ARCE, P., FORT, R., \& ÁLVAREZ, M. La aportación de la nanociencia a la conservación de bienes del patrimonio cultural. 2010, Patrimonio cultural de España.

GOULART, PR, SPINELLI, JE, CHEUNG, N. E GARCIA, A. The effects of cell spacing and distribution of intermetallic fibers on the mechanical properties of hypoeutectic Al-Fe alloys. Materials Chemistry and Physics, v. 119, pp. 272-278, 2010.

GU, W. Y., YAO, H., VEGA, A. L., \& FLAGLER, D. Diffusivity of ions in agarose gels and intervertebral disc: effect of porosity. Annals of biomedical engineering, v. 32, n. 12, p. 1710-1717, 2004.

GUAGLIANONI, W. C., GARCIA, A. P., BASEGIO, T. M., \& BERGMANN, C. P. Microstructural characterization and photocatalytic activity of zinc oxide nanostructured synthesized by combustion in solution. Tecnologia em Metalurgia, v. 12, n. 2, p. 153-158, 2015.

GURUNATHAN, S., RAMAN, J., MALEK, S. N. A., JOHN, P. A., \& VIKINESWARY, S. Green synthesis of silver nanoparticles using Ganoderma neo-japonicum Imazeki: a potential cytotoxic agent against breast cancer cells. International journal of nanomedicine, v. 8 , p. 4399, 2013. 
HABIBI, Y., LUCIA, L. A., \& ROJAS, O. J. Cellulose nanocrystals, 2010, Chemistry, self-assembly, and applications. Chemical Reviews.

HAO, T; XIAO-BAI, Z; XIAO-LU, L. I. U. Effect of magnesium hydroxide on the flame retardant properties of unsaturated polyester resin. Procedia Engineering, v. 52, p.336-341, 2013.

HASSAN, E. A.; HASSAN, M. L.; OKSMAN, K. Improving bagasse pulp paper sheet properties with microfibrilated cellulose isolated from xylanasetreated bagasse. Wood and Fiber Science, Madison, v. 43, n. 1, p. 76-82, 2011.

HENA, S., FATIHAH, N., TABASSUM, S., LALUNG, J., \& JING, S. $Y$. Magnetophoretic harvesting of freshwater microalgae using polypyrrole/Fe 304 nanocomposite and its reusability. Journal of applied phycology, v. 28, n. 3, p. 1597-1609, 2016.

HENRIST, C.; MATHIEU, J. P.; VOGELS, C.; RULMONT, A.; CLOOTS, R. Morphological study of magnesium hydroxide nanoparticles precipitated in dilute aqueous solution. Journal of Crystal Growth, v. 249, p. 321-330, 2003.

HOENICH, N. Cellulose for medical applications: past, present and future. BioRescources, v. 1, n. 2, p.270-280, 2006.

HSIEH, YC, YANO, H., NOGI, M., E EICHHORN, SJ. An estimation of the Young's modulus of bacterial cellulosefilaments. Cellulose, v. 15, p. 507-513, 2008.

HUBBE, M. A., ROJAS, O. J., LUCIA, L. A., \& SAIN, M. Cellulosic nanocomposites: a review. Bio Resources, v. 3, n. 3, p. 929-980, 2008. 
INDA, YASUSHI; OHARA, KAZUO. Glass-ceramic composite electrolyte and lithium secondary cell. U.S. Patent n. 6,475,677, 5 nov. 2002.

IOELOVICH, MICHAEL. Cellulose as a nanostructured polymer: a short review. BioResources, v. 3, n. 4, p. 1403-1418, 2008.

IOELOVICH, M.; LEYKIN, A.; FIGOVSKY, O. Study Of Cellulose Para Crystal linity: 2010 Bioresources.

ISHIZU. A. Chemical modification of cellulose. In: HON, D. Wood and cellulosic chemistry. Tokyo: Marcel Dekker, 1991. v. 1, p. 525.

JALAJERDI, R.; GHORBANALI, M.; MOHAMMADI, A. Synthesis Magnesium Hydroxide Nanoparticles and Cellulose Acetate- $\mathrm{Mg}(\mathrm{OH})_{2}$ -MWCNT Nanocomposite. v. 5, p. 175-181, 2015.

JASIUKAITYTĖ-GROJZDEK, EDITA; KUNAVER, MATJAŽ;; POLJANŠEK, IDA. Influence of cellulose polymerization degree and crystallinity on kinetics of cellulose degradation. BioResources, v. 7 , n. 3, p. 30083027, 2012.

JEGATHEESAN, V., LIOW, JL, SHU, L., KIM, SH E VISVANATHAN, C. The need for global coordination in sustainable development. Journal of Cleaner Production, v. 17, n. 7, p. 637-643, 2009.

JOHNSON, A. S.; OBOT, I. B.; UKPONG, U. S. Green synthesis of silver nanoparticles using Artemisia annua and Sida acuta leaves extract and their antimicrobial, antioxidant and corrosion inhibition potentials. J. Mater. Environ. Sci, v. 5, n. 3, p. 899-906, 2014.

Joseph, K.; MedeiRos, E. S.; CARVALHO, L. H. Polímeros. CiencTecnol., v. 9,p.136-141, 1999.51 
JOSEPH, P.V. Studies on short Sisal Fibre reinforced Isotactic Polypropylene Composites. 2001, PhD Thesis. Mahatma Gandhi University, India.

KABIR, M. M., WANG, H., LAU, K. T., \& CARDONA, F. CHEMICAL treatments on plant-based natural fibre reinforced polymer composites: An overview. Composites Part B: Engineering, v. 43, n. 7, p. 2883-2892, 2012.

KHALIL, H. A., DAVOUDPOUR, Y., ISLAM, M. N., MUSTAPHA, A., SUDESH, K., DUNGANI, R., \& JAWAID, M. Production and modification of nanofibrillated cellulose using various mechanical processes: a review. Carbohydrate polymers, v. 99, p. 649-665, 2014.

KITAMURA, AKANE. The Hydration Characteristics of Magnesia. Taikabutsu, v. 48, p. 112-122, 1996.

KLEBA, I.; ZABOLD, J. Poliuretano com fibras naturais ganha espaço na indústria automotiva. Plástico Industrial, v.75, p.88-99, 2004

KOUZU, M., KASUNO, T., TAJIKA, M., SUGIMOTO, Y., YAMANAKA, S., \& HIDAKA, J. Calcium oxide as a solid base catalyst for transesterification of soybean oil and its application to biodiesel production. Fuel, v. 87, n. 12, p. 2798-2806, 2008.

KONG, DEXU; WILSON, LEE D. Synthesis and characterization of cellulose-goethite composites and their adsorption properties with roxarsone. Carbohydrate polymers, v. 169, p. 282-294, 2017.

LA RUSSA, M. F., RUfFOlO, S. A., ROVELLA, N., BELFIORE, C. M., PALERMO, A. M., GUZZI, M. T., \& CRISCI, G. M. Multifunctional TiO2 coatings for cultural heritage. Progress in Organic Coatings, v. 74, n. 1, p. 186-191, 2012. 
LADEIRA, A. C. Q., CIMINELLI, V. S. T., DUARTE, H. A., ALVES, M. C. M., \& RAMOS, A. Y. Mechanism of anion retention from EXAFS and density functional calculations: Arsenic (V) adsorbed on gibbsite. Geochimica et Cosmochimica Acta, v. 65, n. 8, p. 1211-1217, 2001.

LAVOINE, N. DESLOGES, I.; DUFRESNE, A.; BRAS, J. Microfibrillated cellulose -its barrier properties and applications in cellulosic materials: a review. Carbo hydrate polymers, p. 735-64, 2012.

LEÃO, A. L. Produção de compósitos não estruturais a base de lignocelulósicos. Botucatu, 1997, 147 p. Tese (Livre Docência) FCAUNESP.

LENGOWSKI, ELAINE CRISTINA. Caracterização e predição da cristalinidade de celulose através de espectroscopia no infravermelho e análise multivariada. Tese de Doutorado. Dissertação (Mestrado em Engenharia Florestal). Setor de Ciências Agrárias, 2012.

LI, X., ZHANG, K., SHI, R., MA, X., TAN, L., JI, Q., \& XIA, Y. Enhanced flame-retardant properties of cellulose fibers by incorporation of acid-resistant magnesium-oxide microcapsules. Carbohydrate polymers, v. 176, p. 246-256, 2017.

LAOUTID, F., BONNAUD, L., ALEXANDRE, M., LOPEZ-CUESTA, J. M., \& DUBOIS, $P$. New prospects in flame retardant polymer materials: from fundamentals to nanocomposites. Materials science and engineering: R: Reports, v. 63, n. 3, p. 100-125, 2009.

LU, SHUI-YU; HAMERTON, IAN. Recent developments in the chemistry of halogen-free flame retardant polymers. Progress in polymer science, v. 27, n. 8, p. 1661-1712, 2002. 
LUZ, S. M.; GONÇALVES, A. R.; DEL'ARCO, A. P. Mechanical behavior and microstructural analysis of sugarcane bagasse fibers reinforced polypropylene composites. Composites: Part A, v.38, p1455-1461, 2007.

MAHANINIA, M. H.; WILSON, L. D. Phosphate uptake studies of crosslinked chitosan bead materials. Journal of colloid and interface science, v. 485, p. 201-212, 2017.

MAITAM, M. V. G.; DA COSTA JUNIOR, E. F.; SOUZA, A. O. Modelagem fenomenológica e em regime estacionário do processo de recuperação kraft. 2012.

MAKHLUF, S., DROR, R., NITZAN, Y., ABRAMOVICH, Y., JELINEK, R., \& GEDANKEN, A. Microwave-assisted synthesis of nanocrystalline $\mathrm{MgO}$ and its use as a bacteriocide. Advanced Functional Materials, v. 15, n. 10, p. 1708-1715, 2005.

MARTINS, JULIANI CONTI. Avaliação das propriedades retardantes de chama de hidróxidos de magnésio e alumínio com fibra de vidro em polipropileno. Revista Técnico Científica do IFSC, p. 94, 2011.

MARTINS, MARIA ALICE; JOEKES, INES. Tire rubber-sisal composites: Effect of mercerization and acetylation on reinforcement. Journal of Applied Polymer Science, v. 89, n. 9, p. 25072515, 2003.

MATOS, C.; BARRETO, L.; GIMENEZ, I. Influência da Brucita $\left(\mathrm{Mg}(\mathrm{OH})_{2}\right)$ preparada a partir da Carnalita $(\mathrm{KCl} . \mathrm{MgCl} 2.6 \mathrm{H} 2 \mathrm{O})$ na decomposição térmica de PMMA. Sociedade Brasileira de Química, 2002. 
MESHKANI, FERESHTEH; REZAEI, MEHRAN. Facile synthesis of nanocrystalline magnesium oxide with high surface area. Powder Technology, v. 196, n. 1, p. 85-88, 2009.

MIMMS, A. Kraft pulping, a compilation of notes. 2ed. Atlanta. TAPPI PRESS, p.181,1993.

MOHANTY, A. K.; WIBOWO, A.; MISRA, M.; DRZAL, L. T. Effect of process engineering on the performance of natural fiber reinforced cellulose acetate biocomposites. Composites: Part A, v.35, p.363-370, 2004.

MOHR, BENJAMIN J. Durability of pulp fiber-cement composites. 2005. Tese de Doutorado. Georgia Institute of Technology.

MOON, R. J., MARTINI, A., NAIRN, J., SIMONSEN, J., \& YOUNGBLOOD, J. Cellulose nanomaterials review: structure, properties and nanocomposites. Chemical Society Reviews, v. 40, n. 7, p. 3941-3994, 2011.

MOREIRA, MARIA REJANE. Natureza das interações celulose-água. 2009. Tese de Doutorado. Universidade de São Paulo.

MOTHÉ, C., AZEVEDO, A., DRUMOND, W., \& WANG, S. Thermal properties of amphiphilic biodegradable triblock copolymer of L, Llactide and ethylene glycol. Journal of Thermal Analysis and Calorimetry, v. 101, n. 1, p. 229-233, 2009.

MULINARI, D. R. Comportamento térmico, mecânico e morfológico dos compósitos de polietileno de alta densidade reforçados com fibras de celulose do bagaço de cana de açúcar. Tese de Doutorado, Faculdade de Engenharia Campus de Guaratinguetá, Universidade Estadual Paulista, Guaratinguetá/SP, 2009. 
MUSSATTO, SOLANGE I.; FERNANDES, MARCELA; ROBERTO, INÊS C. Lignin recovery from brewer's spent grain black liquor. Carbohydrate Polymers, v. 70, n. 2, p. 218-223, 2007.

NGUYEN, NYT, GRELLING, N., WETTELAND, CL, ROSÁRIO, R., \& LIU, $\mathrm{H}$. Antimicrobial Activities and Mechanisms of Magnesium Oxide Nanoparticles (nMgO) against Pathogenic Bacteria, Yeasts, and Biofilms. Scientific reports, v. 8, n. 1, p. 16260, 2018.

NUNES, REGINA CÉLIA R.; VISCONTE, LEILA LY; CANAUD, CRISTINE. Propriedades Mecânicas e de Inflamabilidade de Composições de Borracha EPDM Carregadas com Negro de Fumo e Hidróxido de Alumínio. Polímeros Ciência e Tecnologia, v. 11, n. 1, p. 35-40, 2001.

OLSSON, L.; SOERENDEN, H. R.; DAM, B. P.; CHRISTENSEN, H.; KROGH, K. M.; MEYER, A. S. Separate and simultaneous enzymatic hydrolysis and fermentation of wheat hemicellulose with recombinant xylose utilizing Saccharomyces cerevisiae. Applied Biochemistry and Biotechnololgy, v. 129, n. 1-3, p.117-129, p. 117-129, 2006.

PACKHAM, D. E. Adhesive technology and sustainability. International Journal of Adhesion and Adhesives, v. 29, n. 3, p. 248-252, 2009.

PAUL, D. R.; ROBESON, LIOYD M. Polymer nanotechnology: nanocomposites. Polymer, v. 49, n. 15, p. 3187-3204, 2008.

PAIST, WALTER D. Cellulosics. Soil Science, v. 86, n. 4, p. 226, 1958.

PHILIPP, ROSEMARIE; FUJIMOTO, KAORU. Estudo espectroscópico de FTIR da adsorção / dessorção de dióxido de carbono em catalisadores de magnésia / óxido de cálcio. The Journal of Physical Chemistry, v. 96, n. 22, p. 9035-9038, 1992. 
PÜTÜN, ERSAN. Catalytic pyrolysis of biomass: Effects of pyrolysis temperature, sweeping gas flow rate and MgO catalyst. Energy, v. 35, n. 7, p. 2761-2766, 2010.

RAZERA, I. A. T., \& FROLLINI, E. Composites based on jute fibers and phenolic matrices: 2003, Properties of fibers and composites. Journal of Applied Polymer Science, p. 1077-1085.

REYNAUD, E.; GAUTHIER, C.; PEREZ, J. Nanophases in polymers. Revue de Metallurgie, v. 96, n. 2, p. 169-176, 1999.

RIBEIRO FILHO, F.A; DE ALBUQUERQUE BROCCHI, E; MOURA, F. J. Carbocloração do pentóxido de $\mathbf{v}$ anádio. Engenharia Metalúrgica do Departamento de Ciência dos Materiais e Metalurgia da PUC-Rio. 2005.

ROTHON, R. N.; HORNSBY, P. R. Flame retardant effects of magnesium hydroxide. Polymer Degradation and Stability, v. 54, n. 2-3, p. 383-385, 1996.

ROWELL, R. M., SANADI, A. R., CAULFIELD, D. F., \& JACOBSON, R. E. Utilization of natural fibers in plastic composites: problems and opportunities. Lignocellulosic-plastic composites, p. 23-51, 1997.

SAITO, TSUGUYUKI; ISOGAI, AKIRA. Tempo-mediated oxidation of native cellulose. The effect of oxidation conditions on chemical and crystal structures of the water-insoluble fractions. Biomacromolecules, v. 5, n. 5, p. 1983-1989, 2004.

SALOMAO, RAFAEL; BITTENCOURT, L. R. M.; PANDOLFELLI, V. C. A novel approach for magnesia hydration assessment in refractory castables. Ceramics International, v. 33, n. 5, p. 803-810, 2007.

SANTOS, ESTÁCIO ALVES DOS; SILVA, DIVAN SOARES DA; QUEIROZ FILHO, JOSÉ LEITE DE. Composição química do capim- 
elefante cv. Roxo cortado em diferentes alturas. Revista Brasileira de Zootecnia, p. 18-23, 2001.

SASAKI, SATOSHI; FUJINO, KIYOSHI; TAKÉUCHI, YOSHIO. X-ray determination of electron-density distributions in oxides, $\mathrm{MgO}, \mathrm{MnO}$, $\mathrm{CoO}$, and NiO, and atomic scattering factors of their constituent atoms. Proceedings of the Japan Academy, Series B, v. 55, n. 2, p. 43-48, 1979.

SATYANARAYANA, K.G.; ARIZAGA, G.G.C; WYPYCH, F. Biodegradable Composites Based on Lignocellulosic Fibers - an Overview. Progress in Polymer Science, vol. 34, p. 982-1021, 2009.

SILVA, R., HARAGUCHI, S. K., MUNIZ, E. C., \& RUBIRA, A. F. Applications of lignocellulosic fibers in polymer chemistry and in composites. Química nova, v. 32, n. 3, p. 661-671, 2009.

SCHMIED, F. J., TEICHERT, C., KAPPEL, L., HIRN, U., BAUER, W., \& SCHENNACH, R. What holds paper together: nanometre scale exploration of bonding between paper fibres. Scientific Reports, 2013.

SCOPEL, F., MILANEZ, D. H., DE FARIA, L. I. L., \& GREGOLIN, J. Â. R. Prospecção tecnológica sobre fibras naturais em materiais compósitos a partir da análise de documentos de patente. In: Congresso da associação brasileira de metalurgia, materiais e mineração, 67º, Rio de Janeiro. Anais... Rio de Janeiro. 2012.

SHIH, YENG-FONG. Mechanical and thermal properties of waste water bamboo husk fiber reinforced epoxy composites. Materials Science and Engineering: A, v. 445, p. 289-295, 2007.

SILVA, R., HARAGUCHI, S. K., MUNIZ, E. C., \& RUBIRA, A. F. Applications of lignocellulosic fibers in polymer chemistry and in composites. Química nova, v. 32, n. 3, p. 661-671, 2009. 
SMITH, WILLIAM F.; ROSA, MARIA EMÍLIA. Princípios de ciência e engenharia de materiais. 1998.

SPEYER, ROBERT. Thermal analysis of materials. CRC press, 1993.

TANABE, KOZO; HÖLDERICH, WOLFGANG F. Industrial application of solid acid-base catalysts. Applied Catalysis A: General, v. 181, n. 2, p. 399-434, 1999.

THAKUR, SUMAN; KARAK, NIRANJAN. Castor oil-based hyperbranched polyurethanes as advanced surface coating materials. Progress in Organic Coatings, v. 76, n. 1, p. 157-164, 2013.

WANG, S., CHENG, Q., RIALS, T. G., \& LEE, S. H. Cellulose microfibril/nanofibril and its nanocompsites. In: Proceedings of the 8th Pacific rim bio-based composites symposium. 2006. p. 301-308.

WANG, GUOPING; ZHANG, LEI; ZHANG, JIUJUN. A review of electrode materials for electrochemical supercapacitors. Chemical Society Reviews, v. 41, n. 2, p. 797-828, 2012.

YANG, H.; YAN, R.; CHEN, H.; LEE, D.H.; ZHENG, C. Characteristics ofhemicelluloses, cellulose and lignin pyrolysis. Energy Fuel; v. 86, p. $1781-1788,2007$.

YANO, H; NAKAGAITO, A. N. The effect of morphological changes from pulp fiber towards nano-scale fibrilated cellulose on the mechanical properties of high-stregth plant fiber based composites. Applied Physics A- -Materials Science \& Processing, n.78, n. 4, p. 547552, 2004.

YURYEV, R., BRIECHLE, S., GRUBER-KHADJAWI, M., GRIENGL, H., \& LIESE, A. Asymmetric Retro-Henry Reaction Catalyzed by 
Hydroxynitrile Lyase from Hevea brasiliensis. ChemCatChem, v. 2, n. 8, p. 981-986, 2010.

ZANATTA, E. R., SCHEUFELLE, F. B., REINEHR, T. O., SILVA, E. A. D., \& SANTOS, J. B. O. D. Estudo cinético de decomposição térmica da celulose. Revista Eletrônica Científica Inovação e Tecnologia, v. 1, n. 5, p. 30-34, 2012.

ZANG, S.; HORROCKS, A. R. A review of flame retardant polypropylene fibres. Progress in Polymers Science. n.28, 2003, p. 1517-1538.

ZHANG, K., ZONG, L., TAN, Y., JI, Q., YUN, W., SHI, R., \& XIA, $Y$. Improve the flame retardancy of cellulose fibers by grafting zinc ion. Carbohydrate polymers, v. 136, p. 121-127, 2016.

ZHAO, HONG; DARWIN, DAVID. Quantitative backscattered electron analysis of cement paste. Cement and concrete research, v. 22, n. 4, p. 695-706, 1992.

ZHAO, Z., JACOVETTY, E. L., LIU, Y., \& YAN, H. Encapsulation of gold nanoparticles in a DNA origami cage. Angewandte Chemie, v. 123, n. 9, p. 2089-2092, 2011.

ZHENG, G., CUI, Y., KARABULUT, E., WÅGBERG, L., ZHU, H., \& HU, L. Nanostructured paper for flexible energy and electronic devices. $P$. 320-325, 2013, MRS Bulletin.

ZHU, J. Y; ZHU, W.; BRYAN, O. P.; DIEN, B. S; TIAN, S.; GLEISNER, R.; $P A N, X$. J. Ethanol production from sporl-pretreated lodgepole pine: preliminary evaluation of mass balance and process energy efficiency. Applied microbiology and biotechnology, v.86, n. 5, p. 13551365, 2010. 